US Army Corps of Engineers $s_{\circledast}$

Engineer Research and

Development Center

Risk Assessment Planning and Tools for OpeRations (RAPTOR)

\title{
Projecting Shifts in Human and Ecological Zones
}

Kayla A. Cotterman, James D. Westervelt, Jeanne M. Roningen,

September 2019 and Angela M. Rhodes

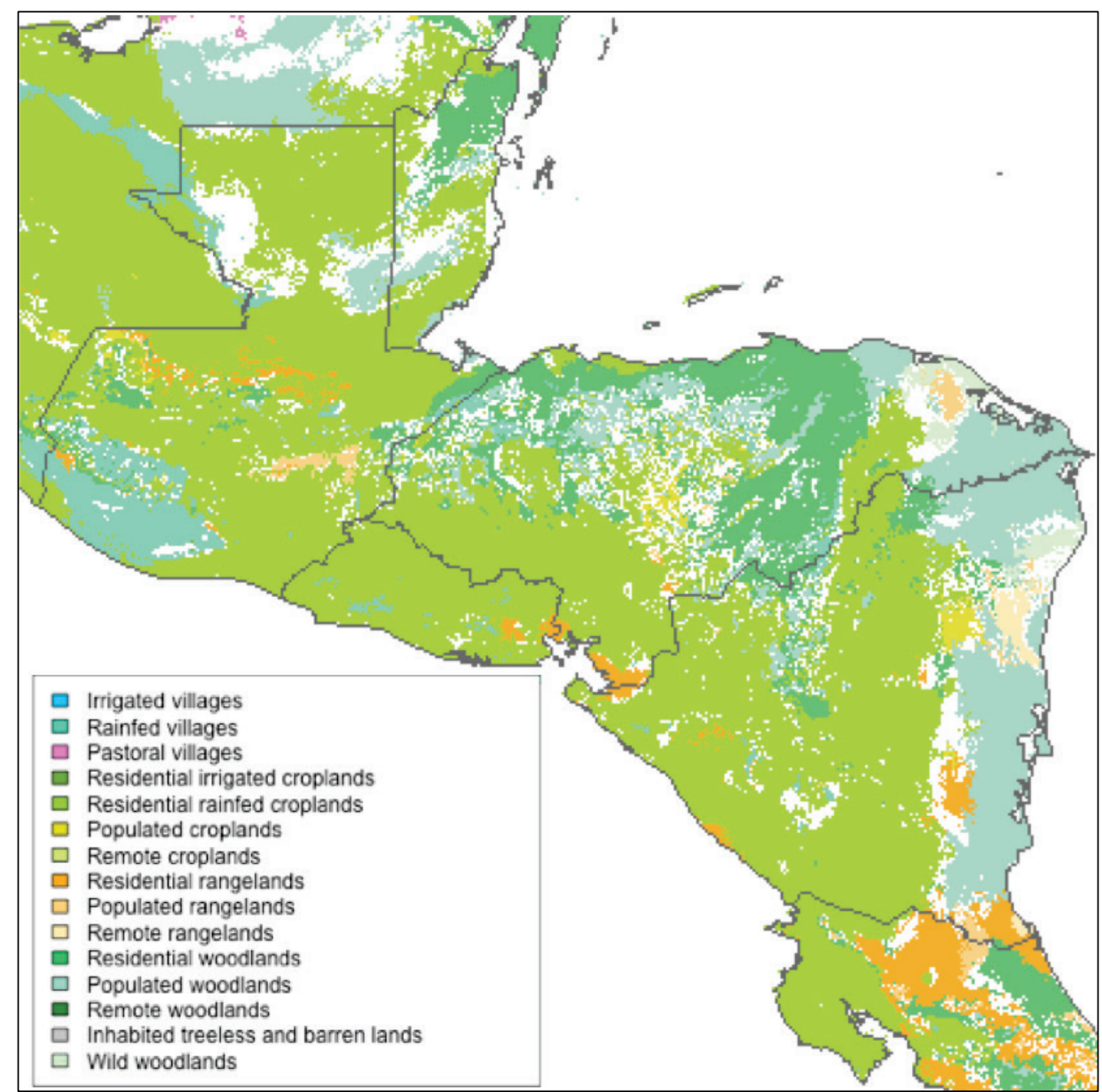


The U.S. Army Engineer Research and Development Center (ERDC) solves the nation's toughest engineering and environmental challenges. ERDC develops innovative solutions in civil and military engineering, geospatial sciences, water resources, and environmental sciences for the Army, the Department of Defense, civilian agencies, and our nation's public good. Find out more at www.erdc.usace.army.mil.

To search for other technical reports published by ERDC, visit the ERDC online library at http://acwc.sdp.sirsi.net/client/default. 


\section{Projecting Shifts in Human and Ecological Zones}

Kayla A. Cotterman

Coastal and Hydraulics Laboratory

U.S. Army Engineer Research and Development Center

3909 Halls Ferry Road

Vicksburg, MS 39180-6199

James D. Westervelt and Angela M. Rhodes

Construction Engineering Research Laboratory

U.S. Army Engineer Research and Development Center 2902 Newmark Drive

Champaign, IL 61822

Jeanne M. Roningen

Cold Regions Research and Engineering Laboratory

U.S. Army Engineer Research and Development Center

72 Lyme Road

Hanover, NH 03755

Final report

Approved for public release; distribution is unlimited.

Prepared for U.S. Army Engineer Research and Development Center Construction Engineering Research Laboratory

Office of the Technical Director 2902 Newmark Dr.

Champaign, IL 61822

Under Project No. 477345, "RAPTOR" 


\section{Abstract}

As the human population approaches 7.7 billion, Earths capacity to support human life is stretched. There are declining opportunities for the expansion of human agriculture and settlements into new places. Additionally, there is an expected increase in the motivation for local people to defend land that currently supports the production of essential food and water. As climate non-stationarity continues, changes in the productivity of local food and water supply could result in starvation or surpluses. This study addresses the following question regarding the future potential of land resources to support local populations with food and water: How might existing ecological and anthropogenic biomes shift over the twenty-first century? Recent historic ecological and anthropogenic biome maps are statistically correlated with recent historic climate to generate models. These are then applied to anticipated future climates to generate future biome and anthrome maps. These maps are evaluated and summarized to suggest how the future climate might change and affect land use patterns. This analysis is constrained to the area of Central America over the course of the twentyfirst century based on the results of recent climate models. However, it is a goal of the authors that the methods developed in this work can be applied to other regions of the world.

DISCLAIMER: The contents of this report are not to be used for advertising, publication, or promotional purposes. Citation of trade names does not constitute an official endorsement or approval of the use of such commercial products. All product names and trademarks cited are the property of their respective owners. The findings of this report are not to be construed as an official Department of the Army position unless so designated by other authorized documents. 


\section{Contents}

Abstract............................................................................................................................... if

Figures and Tables......................................................................................................................................

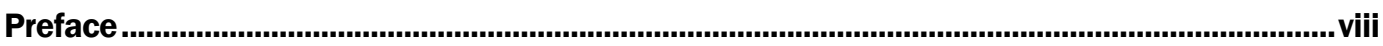

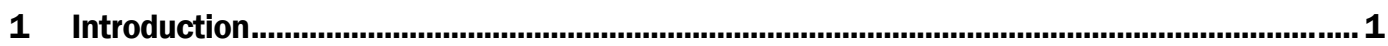

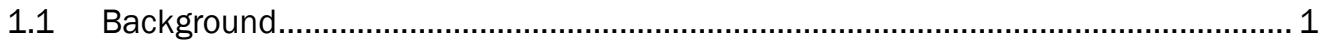

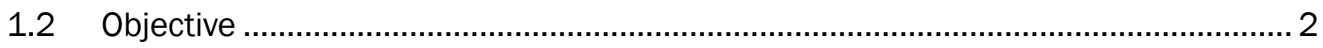

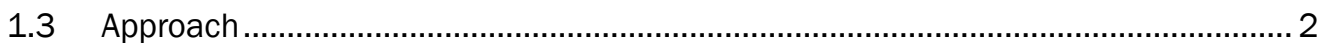

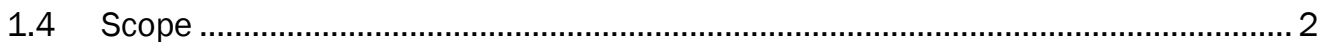

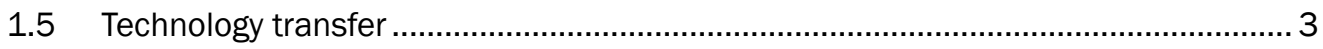

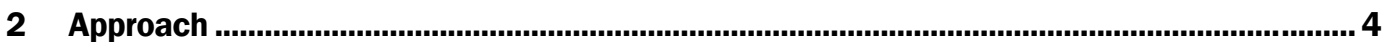

2.1 Ecological biomes................................................................................................. 4

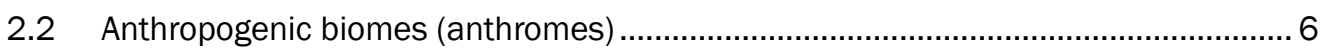

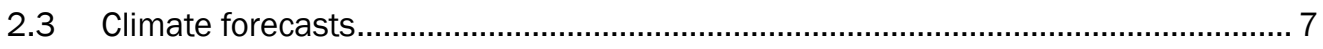

2.4 Bioclimatic indices ......................................................................................... 11

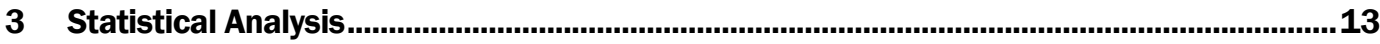

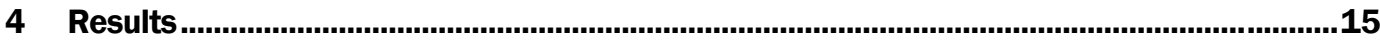

4.1 Ecosystem shift pressures............................................................................ 15

4.1.1 Central American Atlantic Moist Forest (Table 25 through Table 27) .................. 15

4.1.2 Isthmian-Atlantic Moist Forests (Table 28 through Table 30).............................. 18

4.1.3 Pantanos de Centla (Table 31 through Table 33)................................................ 19

4.1.4 Southern Pacific Dry Forests (Table 34 through Table 36) ..................................20

4.1.5 Neotropic (Table 37 through Table 39) ............................................................. 21

4.1.6 Petén-Veracruz Moist Forest (Table 40 through Table 42).................................. 22

4.1.7 Sierra Madre De Chiapas Moist Forest (Table 43 through Table 45)...................24

4.1.8 Veracruz Moist Forests (Table 46 through Table 48) ........................................... 25

4.1.9 Yucatán Moist Forests (Table 49 through Table 51) ........................................... 25

4.1.10 Central American Dry Forests (Table 52 through Table 54)................................ 26

4.1.11 Yucatán Dry Forests (Table 55 through Table 57) .............................................. 28

4.1.12 Central American Pine-Oak Forests (Table 58 through Table 60) ......................... 29

4.1.13 Miskito Pine Forests (Table 61 through Table 63) ................................................ 31

4.1.14 Mesoamerican Gulf-Caribbean Mangroves (Table 64 through Table 66).............32

4.1.15 Southern Mesoamerican Pacific Mangroves (Table 67 through Table 69)........... 34

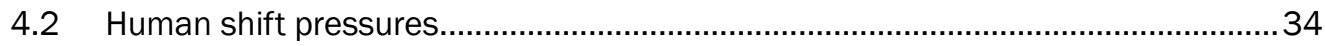

4.2.1 Rainfed villages (Table 4 through Table 6)......................................................... 35

4.2.2 Residential rainfed croplands (Table 7 through Table 9) ..................................... 37

4.2.3 Populated croplands (Table 10 through Table 12) .............................................40

4.2.4 Residential rangelands (Table 13 through Table 15) ......................................... 41

4.2.5 Residential woodlands (Table 16 through Table 18)............................................42

4.2.6 Populated woodlands (Table 19 through Table 21).......................................... 45 
4.2.7 Wild woodlands (Table 22 through Table 24) .................................................4 47

4.3 Comparison of wet versus dry GCMs ........................................................... 48

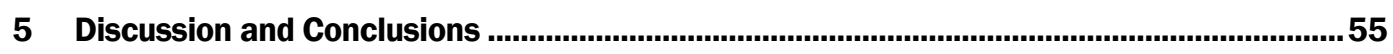

References....................................................................................................................................58

Appendix: Anthromes and Biomes Percentages ......................................................................60

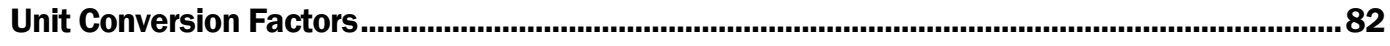

Report Documentation Page 


\section{Figures and Tables}

\section{Figures}

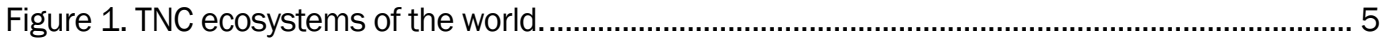

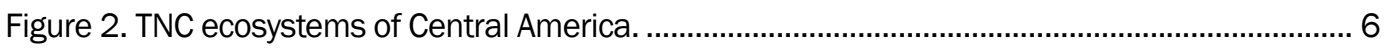

Figure 3. Anthropogenic biomes of Central America. ………........................................................... 7

Figure 4. Changes in precipitation for RCP 8.5, 2080-2100. Each image represents a different GCM used in this analysis referenced in Table 2. The scale bar on the right indicates changes in precipitation (in millimeters per year) with browns for decrease in precipitation in the future and blues for increase........................................................................ 10

Figure 5. Anthrome projections for the 2080s epoch for RCP 8.5 using the CSIRO-Mk3.6.0 GCM representing the driest simulation................................................................................... 50

Figure 6. Anthrome projections for the 2080s epoch for RCP 8.5 using GFDL CM3 GCM representing the wettest simulation......................................................................................... 51

Figure 7. Biome projections for the 2080s epoch for RCP 8.5 using CSIRO-Mk3.6.0 GCM

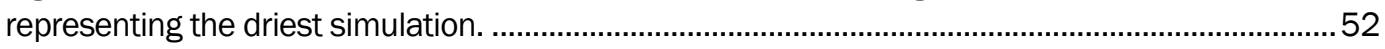

Figure 8. Biome projections for the 2080s epoch for RCP 8.5 using GFDL CM3 GCM representing the wettest simulation........................................................................................... 53

\section{Tables}

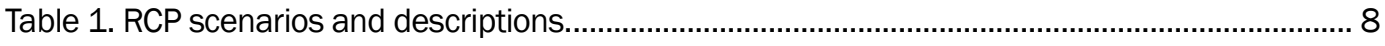

Table 2. Climate models (IPCC-5) . ...................................................................................... 9

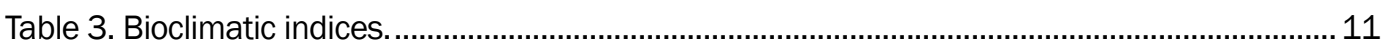

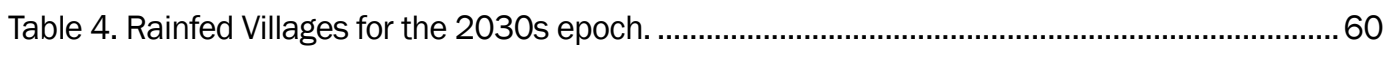

Table 5. Rainfed Villages for the 2050s epoch. ............................................................................60

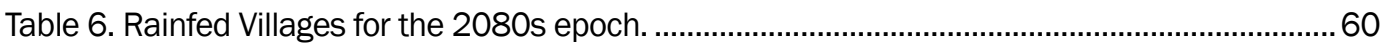

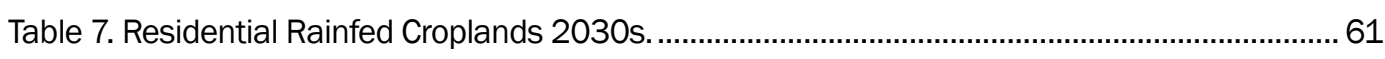

Table 8. Residential Rainfed Croplands 2050s..................................................................................... 61

Table 9. Residential Rainfed Croplands 2080s.......................................................................... 61

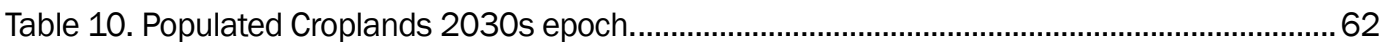

Table 11. Populated Croplands 2050s epoch............................................................................ 62

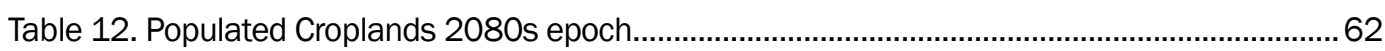

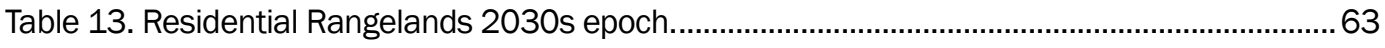

Table 14. Residential Rangelands 2050s epoch.........................................................................63

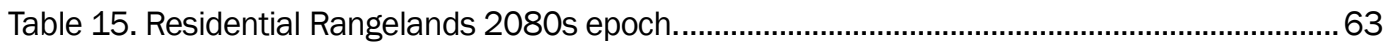

Table 16. Residential Woodlands 2030s epoch.......................................................................... 64

Table 17. Residential Woodlands 2050s epoch........................................................................... 64

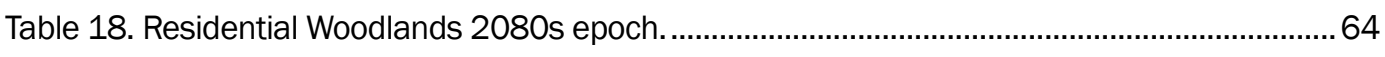

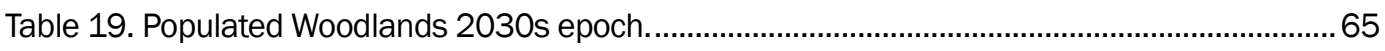

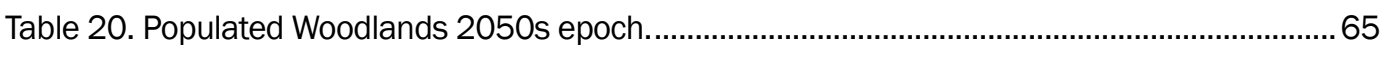

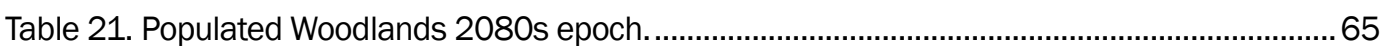


Table 22. Wild Woodlands 2030s epoch..........................................................................................6

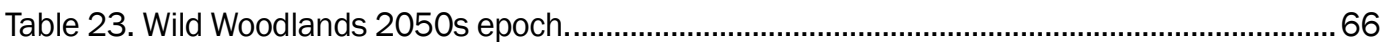

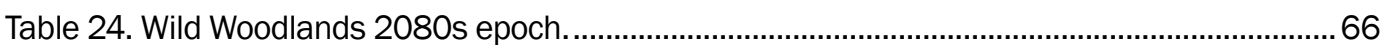

Table 25. Central American Atlantic Moist Forests 2030s epoch....................................................67

Table 26. Central American Atlantic Moist Forests 2050s epoch.................................................67

Table 27. Central American Atlantic Moist Forests 2080s epoch...................................................67

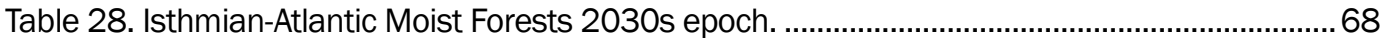

Table 29. Isthmian-Atlantic Moist Forests 2050s epoch. ............................................................. 68

Table 30. Isthmian-Atlantic Moist Forests 2080s epoch. …………….......................................... 68

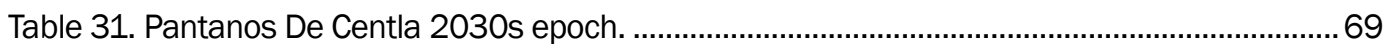

Table 32. Pantanos De Centla 2050s epoch.................................................................................69

Table 33. Pantanos De Centla 2080s epoch.............................................................................. 69

Table 34. Southern Pacific Dry Forests 2030s epoch..................................................................... 70

Table 35. Southern Pacific Dry Forests 2050s epoch...................................................................... 70

Table 36. Southern Pacific Dry Forests 2080s epoch................................................................... 70

Table 37. Neotropic 2030s epoch. ........................................................................................ 71

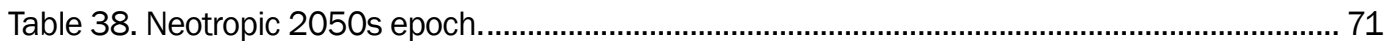

Table 39. Neotropic 2080s epoch........................................................................................ 71

Table 40. Petén-Veracruz Moist Forest 2030s epoch. ………………………………................ 72

Table 41. Petén-Veracruz Moist Forest 2050s epoch........................................................................ 72

Table 42. Petén-Veracruz Moist Forest 2080s epoch. ..................................................................... 72

Table 43. Sierra Madre De Chiapas Moist Forest 2030s epoch..................................................... 73

Table 44. Sierra Madre De Chiapas Moist Forest 2050s epoch......................................................73

Table 45. Sierra Madre De Chiapas Moist Forest 2080s epoch..................................................... 73

Table 46. Veracruz Moist Forests 2030s epoch. ........................................................................

Table 47. Veracruz Moist Forests 2050s epoch. ……………………………………………....

Table 48. Veracruz Moist Forests 2080s epoch. ..............................................................................

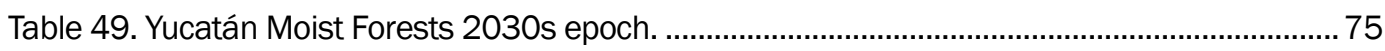

Table 50. Yucatán Moist Forests 2050s epoch. ……………......................................................... 75

Table 51. Yucatán Moist Forests 2080s epoch................................................................................ 75

Table 52. Central American Dry Forests 2030s epoch. ................................................................... 76

Table 53. Central American Dry Forests 2050s epoch. ..................................................................... 76

Table 54. Central American Dry Forests 2080s epoch. ................................................................... 76

Table 55. Yucatán Dry Forests 2030s epoch............................................................................ 77

Table 56. Yucatán Dry Forests 2050s epoch............................................................................ 77

Table 57. Yucatán Dry Forests 2080s epoch............................................................................. 77

Table 58. Central American Pine-Oak Forests 2030s epoch........................................................ 78

Table 59. Central American Pine-Oak Forests 2050s epoch............................................................ 78

Table 60. Central American Pine-Oak Forests 2080s epoch........................................................... 78

Table 61. Miskito Pine Forests 2030s epoch........................................................................... 79 


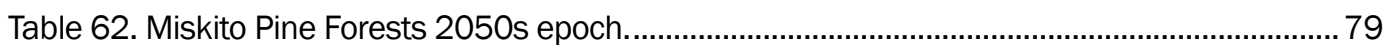

Table 63. Miskito Pine Forests 2080s epoch........................................................................... 79

Table 64. Mesoamerican Gulf-Caribbean Mangroves 2030s epoch............................................... 80

Table 65. Mesoamerican Gulf-Caribbean Mangroves 2050s epoch............................................. 80

Table 66. Mesoamerican Gulf-Caribbean Mangroves 2080s epoch.................................................. 80

Table 67. Southern Mesoamerican Pacific Mangroves 2030s epoch.............................................. 81

Table 68. Southern Mesoamerican Pacific Mangroves 2030s epoch.............................................. 81

Table 69. Southern Mesoamerican Pacific Mangroves 2030s epoch................................................ 81 


\section{Preface}

This study was conducted for the U.S. Army Engineer Research and Development Center (ERDC), Construction Engineering Research Laboratory, Office of the Technical Director, under Project No. 477345, "RAPTOR."

The work was performed by the Hydrologic Systems Branch of the Flood and Stream Protection Division, ERDC, Coastal and Hydraulics Laboratory (CHL). At the time of publication of this report, Dr. HwaiPing Cheng was Branch Chief, and Dr. Cary A. Talbot was Division Chief. The Program Manager was Ms. Angela Rhodes, and the Technical Director was Mr. Ritchie Rodebaugh. The Deputy Director of ERDC-CHL was Mr. Jeffrey R. Eckstein, and the Director was Dr. Ty V. Wamsley.

COL Teresa A. Schlosser was the Commander of ERDC, and the Director was Dr. David W. Pittman. 


\section{Introduction}

\subsection{Background}

The Army continually prepares to meet peacekeeping challenges around the world, which involves anticipating potential human conflicts as far in advance as possible. With enough advanced warning of the development of conflict drivers, it is possible to change the trajectory of history to avoid future conflict or at least to prepare to deal with a challenge effectively and efficiently.

At a fundamental level, plants, animals, and people require food and water, which are commodities irregularly distributed around the world. Over millennia, plants and animals have evolved into species that are adapted to the local availability of food and water. Climate and non-climate aspects impact species; however, climate change can cause physiological limitations on species affecting the level of distribution (O'Donnell and Ignizio 2012). Earth is now covered with a rich diversity of genetics within each species that have allowed them to persist through change. While there have been occasional dramatic changes in the history of Earth that have wiped out species (and their associated genetic diversity), the slow changes in climate and the much slower movements of continents have been met with evolutionary changes in species (Boivin et al. 2016).

In the relatively short timeframe of the story of humans on Earth, people have established cultures and homes in direct response to local temperature and rainfall conditions (climate), which provide the foundation for the establishment of local food production. The impact of climate on a finite supply of available food and water becomes increasingly important as the human population approaches 7.7 billion. There are decreasing opportunities for expanding human agriculture and settlements into new areas. There is an expected increase in the motivation for local people to defend land that currently supports the production of life-giving water and food (Global Witness 2017). As climate continues to vary and shift, land productivity will also shift. In some cases, this may result in currently productive land becoming untenable as the occurrence of drought increases. Where one area experiences an increased occurrence of crop failures and starvation, another may become better suited for crop production. By examining climate temporally, the effects of 
climate change on species distributions for past, present, and future scenarios can be quantified (O’Donnell and Ignizio 2012).

\subsection{Objective}

This document addresses questions regarding the future potential of areas across Central America to continue to support local populations with food and water. While aspects such as degradation caused by human activity can negatively impact land use, this and similar aspects were not examined within this study. This report focuses on how changing climatic conditions can cause land use to shift. The objective is to specifically address these questions as they relate to climatic impacts on food and water availability:

- How might existing ecological biomes shift over the twenty-first century?

- How might anthropogenic biomes (human use of land in the production of food) shift over the twenty-first century?

\subsection{Approach}

This work uses a statistically correlated model (Liaw and Wiener 2002) to combine recently constructed ecological (The Nature Conservancy) and anthropogenic biome maps (Ellis and Ramankutty, 2008) with historic climate (Hijmans et al. 2005). A machine-learning algorithm is applied to project climate impacts on anthrome and biome shifts using projected climate information from the Intergovernmental Panel on Climate Change (IPCC) Fifth Assessment Report (IPCC 2014). These maps are then evaluated and summarized to suggest how shifting climate will impact land use patterns for Central America in the twenty-first century.

This report is a suitability study; the goal is to examine how climate is likely to change causing a shift in suitability for ecosystems and plant growth. However, this report is not predicting what will occur in regards from shifting from one biome/anthrome to a different one, but rather examining probable future scenarios given the current data and future trends based on past events.

\subsection{Scope}

This analysis is constrained to the area of Central America over the course of the twenty-first century based on the results of recent predictive climate 
models. However, it is the goal of the authors that the methods developed in this work can be applied to other regions of the world.

\subsection{Technology transfer}

Maps of each of the climate models, Representative Concentration Pathways (RCP) scenarios, and epochs for biomes and anthromes are produced; these maps can also be analyzed using geographic information system (GIS) software. Additionally, there is numeric output regarding the coverage of each biome and anthrome for each model, RCP scenario, epoch, and country. These maps could be displayed in a web app, such as Tethys, allowing for easy viewing and aid in decision making. 


\section{Approach}

Biomes and anthromes are used to classify the biosphere of Earth. While they examine slightly different aspects, they are related. Biomes are the most fundamental unit of classification used by ecologists to define global patterns of ecosystem types, processes, and biodiversity and are largely mapped on broad differences in type of vegetation accompanied by variations in climate (Ellis and Ramankutty 2008). However, studies have determined that as much as half as Earth's ecosystems are humandominated ecosystems compared to natural ecosystems (Vitousek et al. 2008). Therefore, anthromes take into account how humans interact with ecosystems in the terrestrial biosphere (Ellis and Ramankutty 2008).

\subsection{Ecological biomes}

Many habitat classification maps have been developed for the United States. Early examples include the Bailey $(1983,1995)$ and Omernik (1987) classification maps. Bailey generated maps at three levels of detail, identifying 52 ecoregions at the finest level. For studying water resources, Omernick identified 76 national ecoregions. These maps were created through a combination of computer-assisted classification of mapped data and subjective expert opinion. For the current study, a global ecosystem map was adopted that had been developed by for The Nature Conservancy (TNC), which was adapted from the original works of Olson and Dinerstein (2002), Bailey (1995), and Environment Canada (Wiken 1986). The TNC developed this dataset to be used in its biodiversity planning exercises in the process known as Ecoregional Assessments. Several ecoregions were modified from the originals by TNC staff developing the aforementioned assessments. The ecosystem map employed in this project covers the globe as a unified global representation of ecosystems. Figure 1 shows the global TNC map, and Figure 2 shows the corresponding region of Central America. 
Figure 1. TNC ecosystems of the world.

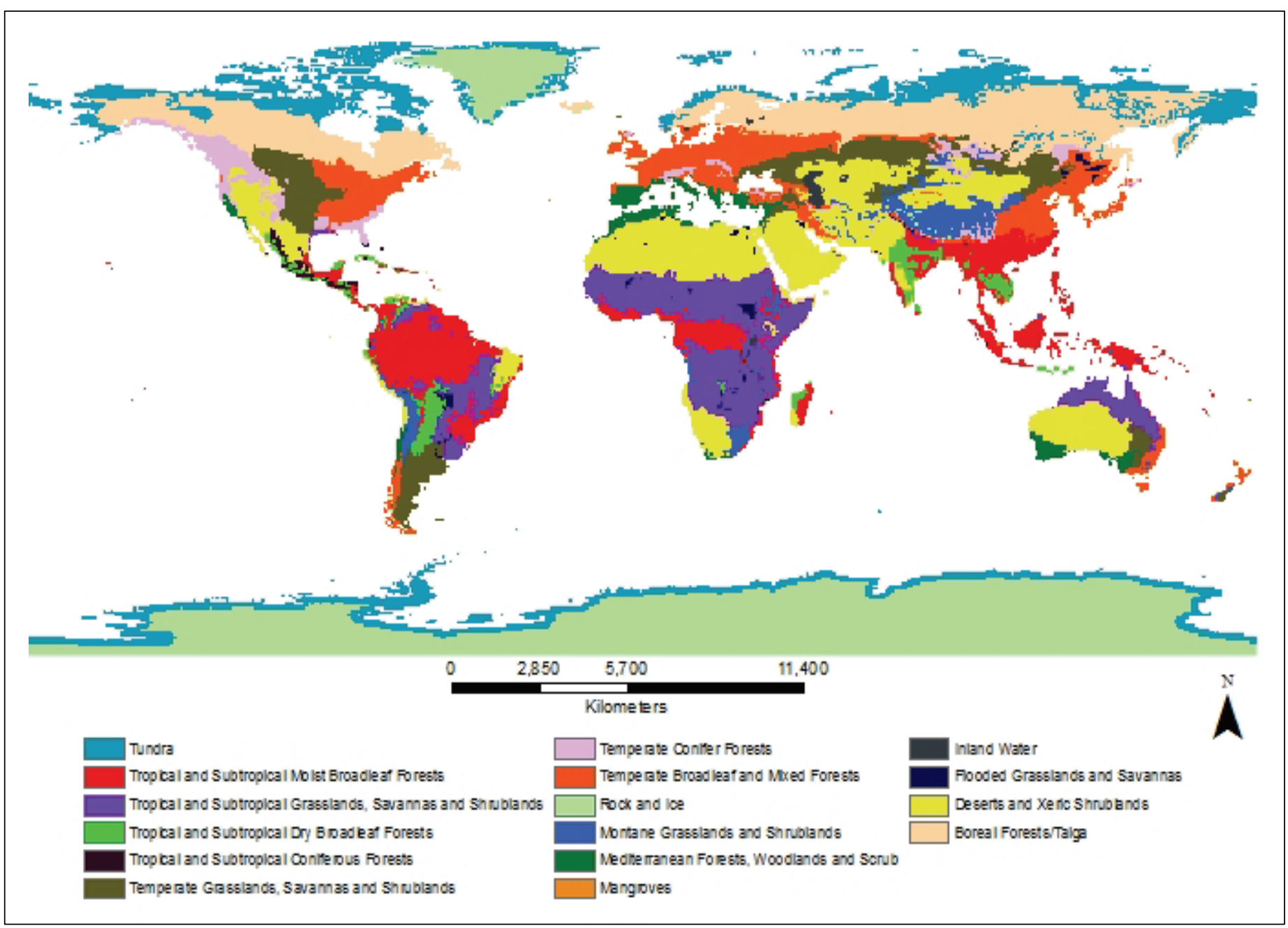


Figure 2. TNC ecosystems of Central America.

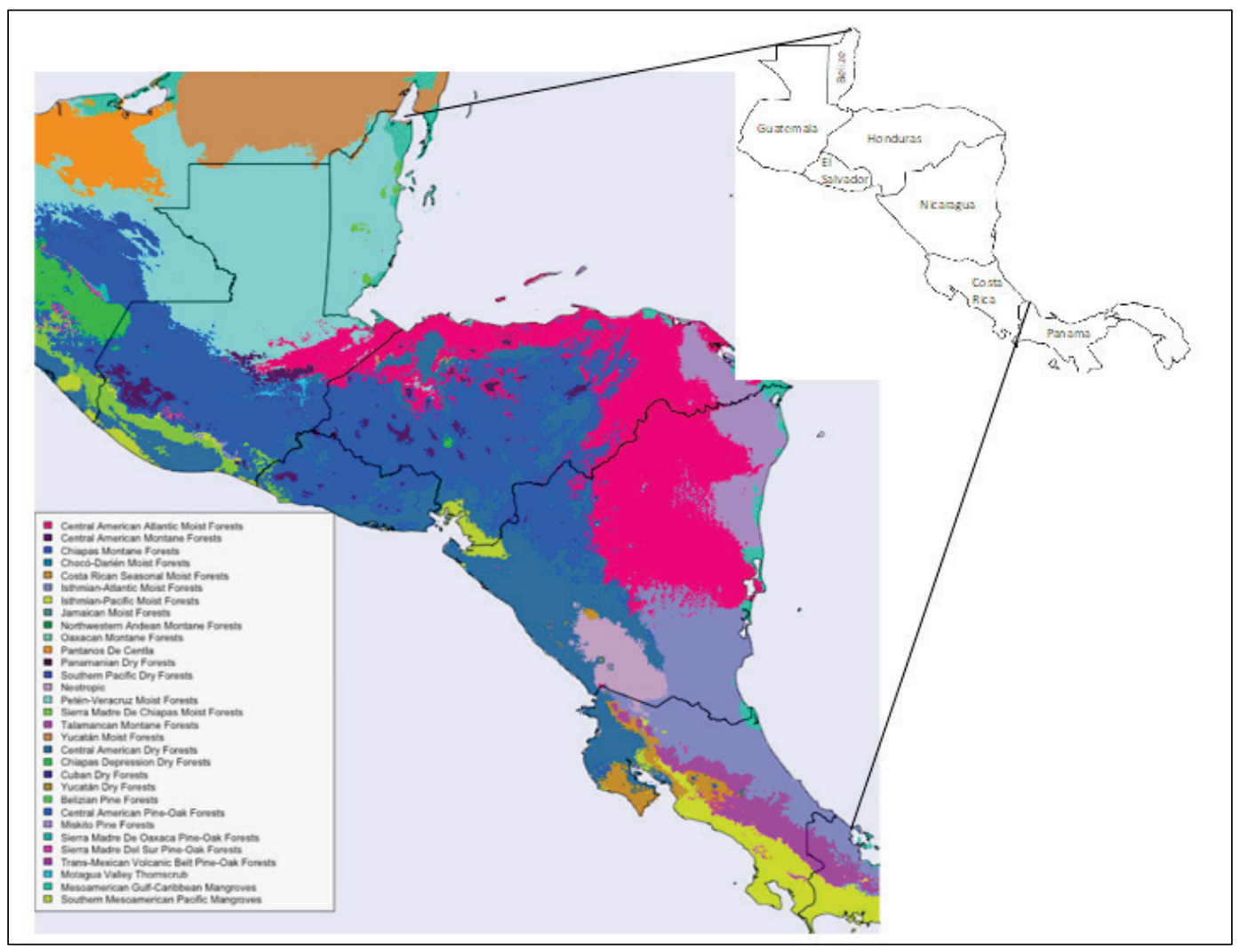

\subsection{Anthropogenic biomes (anthromes)}

The location and extent of ecological systems is, in part, the result of the flora and fauna of the world competing with one another under different climatic conditions. Ellis et al. (2008), adopted this notion but considered how humans have made use of the natural resources of Earth. The image in Figure 3 shows their division of the study area into the various anthropogenic biomes (Ellis and Ramankutty 2008). In general, "rainfed villages" can be found near the Pacific coast (much of El Salvador), "residential rainfed croplands" through the interior, and "populated woodlands" towards the Atlantic, interspersed with "wild woodlands." 
Figure 3. Anthropogenic biomes of Central America.

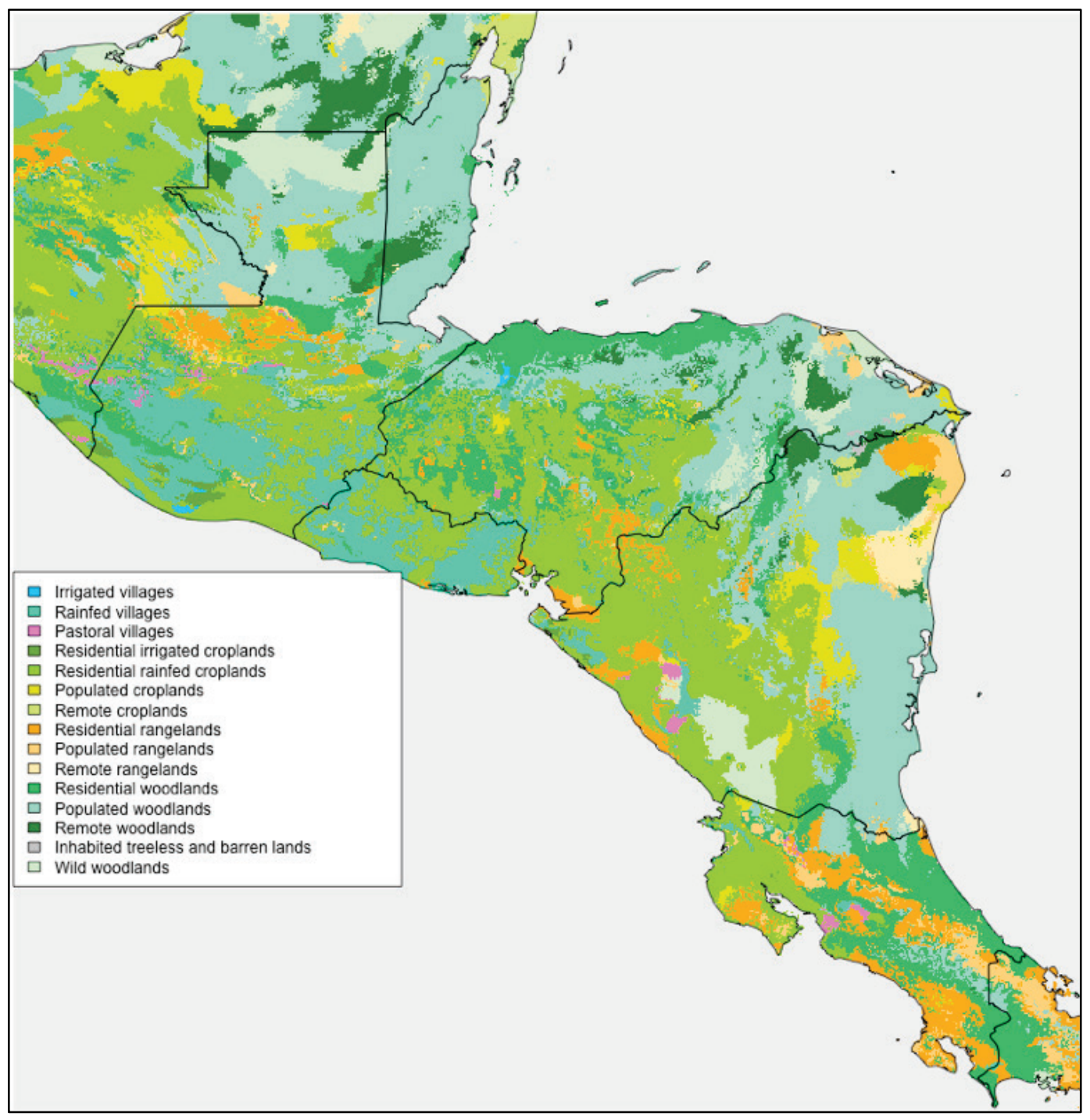

\subsection{Climate forecasts}

Climatic changes are likely to influence human landscapes, specifically the availability of food and water, which are critical needs. Pick any pair of time periods for most any location and discover that the patterns and amounts of rainfall and temperatures were not identical - especially in areas between the equatorial region and the Polar Regions. Differences occur on a daily basis (weather), over months (seasonal), and over decades and longer (climate). There are many repeating cycles at all time scales. A well-known multi-year cycle that dominates multi-year climate variability in Central America is the El Niño-Southern Oscillation. At the height of an El Niño event, the Pacific equatorial surface waters off South America are unusually warm. At the opposite end of this cycle, these waters are 
relatively cool, a result of an upwelling of deep ocean waters, which carry nutrients that result in optimal fishing. This cycle involves the entire portion of the Pacific near the equator and is associated with vast amounts of energy that result in dramatic changes in the generation of rain patterns across much of the earth.

Many natural cycles and events drive the global climate cycles. The elliptical orbits of Earth around the sun and the moon around Earth impact the weather (short-term) and climate (longer-term) patterns, which also change over time. For example, Earth's closest approach to the sun is currently during the winter in the northern hemisphere, but over approximately 24,000 years, changes to coincide with northern hemisphere's summer and then back to winter. The energy output of the sun has an 11-year cycle, which is reflected in cycles of sunspots and solar storms. Terrestrial events such as volcanoes and long-term lava flows can result in years of increased solar reflection, which results in a cooling of Earth.

In recent decades, the weather community has developed increasingly sophisticated mathematical codes that model the three-dimensional movements of air in the atmosphere and water in the oceans, calling this class of software General Circulation Models (GCMs). These models take into account many climate drivers and over time are adding more variables and dynamics have been added to the mathematics. Many governments and institutions have developed dozens of GCMs. Now, every several years a consortium of modelers around the world collaborate as part of the IPCC to run their models against storylines that describe potential future human influx of carbon dioxide $\left(\mathrm{CO}_{2}\right)$ into the global system. For the last completed round of IPCC model runs, four storylines were developed and called RCPs. Table 1 details the differences between the scenarios developed by the IPCC (Meinshausen et al. 2011).

Table 1. RCP scenarios and descriptions.

\begin{tabular}{|l|l|}
\hline RCP Scenario & Global Annual GreenHouse Gas (GHG) Emission Storyline \\
\hline RCP 2.6 & $\begin{array}{l}\text { GHG emissions peak between 2010-2020, with emissions declining } \\
\text { substantially thereafter. }\end{array}$ \\
\hline RCP 4.5 & GHG emissions peak around 2040 and then decline. \\
\hline RCP 6.0 & GHG emissions peak around 2080 and then decline. \\
\hline RCP 8.5 & GHG emissions continue to rise throughout the twenty-first century. \\
\hline
\end{tabular}


For the IPCC- 5 round of climate forecasts, dozens of GCMs were run against the four RCP storylines. Since these models run at a resolution of approximately 2 degrees, results are downscaled to a resolution that allows local consideration of elevations and proximities to coastlines. Statistical downscaling (delta method) is one of the employed approaches (Hijmans et al. 2005). It uses historical differences across the GCM grid cells to convert the values of those cells to values for resolutions at 30 arc seconds.

Then, results were downloaded from the globally available downscaled IPCC-5 climate scenarios from the GCM Downscaled Data Portal, which is supported by the Consultative Group for International Agricultural Research and the Research Program on Climate Change, Agriculture, and Food Security. Downloads included derivative results from all of the models in Table 2 at a resolution of 30 arc-seconds (approximately 0.58 miles or 1 kilometer at the equator) for the four RCP story lines described above and for four epochs (2030s, 2050s, 2070s, and 2080s).

Table 2. Climate models (IPCC-5).

\begin{tabular}{|l|l|}
\hline Model Code & Description \\
\hline bcc_csm1_1 & Beijing Climate Center, China Meteorological Administration \\
\hline cesm1_cam5 & $\begin{array}{l}\text { National Science Foundation, Department of Energy, National } \\
\text { Center for Atmospheric Research }\end{array}$ \\
\hline csiro_mk3_6_0 & $\begin{array}{l}\text { Commonwealth Scientific and Industrial Research Organisation } \\
\text { (CSIRO) in collaboration with the Queensland Climate Change } \\
\text { Centre of Excellence (Australia) }\end{array}$ \\
\hline gfdl_cm3 & Geophysical Fluid Dynamics Laboratory (US) \\
\hline ipsI_cm5a_Ir & Institut Pierre-Simon Laplace (French) \\
\hline
\end{tabular}

Even within a single RCP scenario and decade of analysis, climate model outputs do not agree with respect to the magnitude and direction of change across all variables in all regions of the world. There are some variables, such as temperature, for which model outputs generally agree, if not in the precise magnitude of change then in the direction of change. For other outputs, such as precipitation, there are areas of the world in which most models agree as to the direction of change and other areas where there is no clear direction. These areas are therefore subject to a higher degree of uncertainty. An overview of temperature and precipitation outputs is provided here from the models listed in Table 2 to characterize whether the models on which the subsequent analysis is based exhibit agreement in the area of interest. 
Throughout this century, there is an overall increase in temperature across all of Central America with uniform agreement across all GCMs. As expected, with increasing amounts of $\mathrm{CO}_{2}$ related to $\mathrm{RCP} 4.5$, 6.0, and 8.5, temperatures increase. Similarly, the further into the future, the temperature also increases. Expectedly, RCP 8.5 at the end of the twentyfirst century shows the highest temperatures with an increase of nearly $4-6^{\circ} \mathrm{C}\left(7-11^{\circ} \mathrm{F}\right)$ compared to historic values.

Unlike temperature, precipitation varies widely across Central America as shown in Figure 4. While Figure 4 shows only the last part of the century for RCP 8.5, other RCPs and time periods also exhibit a wide variety of precipitation patterns across Central America. There are a wide variety of projected precipitation changes, ranging from an increase of approximately 600 millimeters $(\mathrm{mm})$ for Geophysical Fluid Dynamics Laboratory (GFDL) $\mathrm{CM}_{3}$ to a decrease of nearly 1,000 mm annually for Queensland Climate Change Centre of Excellence and the Commonwealth Scientific and Industrial Research Organisation (CSIROMk3.6.o). Additionally, within the Central American region, the models disagree on which sub-region will experience an increase or decrease of precipitation. It is expected that these different model outcomes will produce different types of changes to biome and anthrome projections.

Figure 4. Changes in precipitation for RCP 8.5, 2080-2100. Each image represents a different GCM used in this analysis referenced in Table 2. The scale bar on the right indicates changes in precipitation (in millimeters per year) with browns for decrease in precipitation in the future and blues for increase.

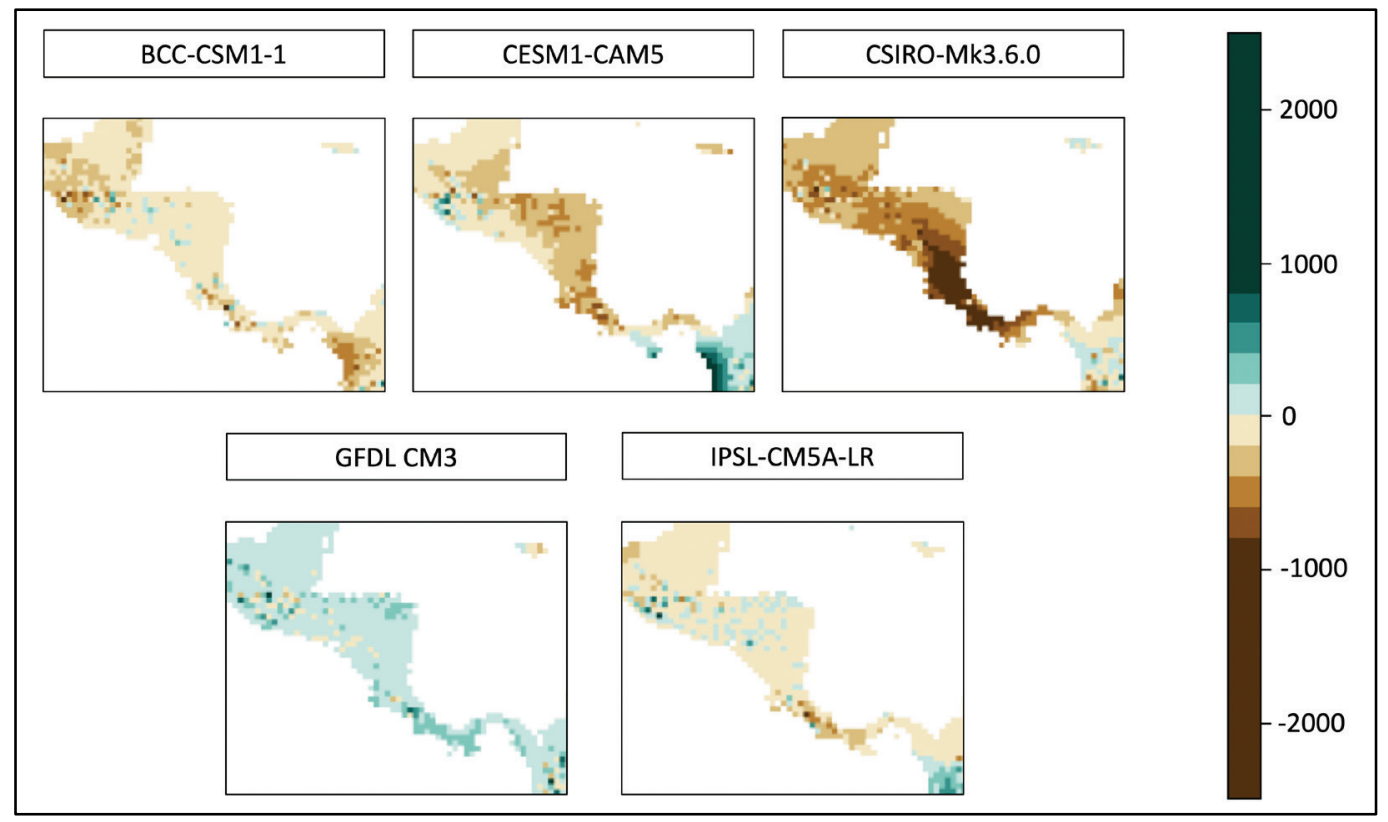




\subsection{Bioclimatic indices}

The raw data results from the climate models are not suitable for forecasting ecological or anthropological biomes. The models run at approximately a 15-minute time-step, generating pseudo weather patterns at a resolution of approximately 1 degree (70 miles) across the earth for the span of the simulation, which is typically 100 years or more. These results must be processed through a number of steps to be able to use. First, the results are not accepted as weather, so they are converted to minimum, maximum, and mean temperature and average rainfall by month across a 10-year period of time (an epoch). Second, the scale is too large and must be downscaled to capture local changes. Downscaling takes into account local details such as elevation, land/water, and proximity to coastlines. The method of downscaling in this analysis uses a highresolution baseline climatology (Hijmans et al. 2005) and the delta method of statistical downscaling (Ramirez-Villegas and Jarvis 2010). Third, to compare locations across the globe, what happens at any given time of the year is irrelevant because the seasons in the northern and southern hemispheres are opposite. Instead, what living things respond to are considerations, such as the average temperature and rainfall during the growing seasons. Therefore, a set of 19 such indices, referred to as bioclimatic indices, as described by ODonnell and Ignizio (2012), has been generally adopted by landscape researchers. These are listed in Table 3 .

Table 3. Bioclimatic indices.

\begin{tabular}{|l|l|}
\hline Index & Description \\
\hline BIO1 & Annual Mean Temperature \\
\hline BIO2 & Mean Diurnal Range (Mean of monthly [max temp - min temp]) \\
\hline BI03 & Isothermality (BIO2/BIO7) (* 100) \\
\hline BI04 & Temperature Seasonality (standard deviation *100) \\
\hline BI05 & Max Temperature of Warmest Month \\
\hline BI06 & Min Temperature of Coldest Month \\
\hline BI07 & Temperature Annual Range (BIO5-BIO6) \\
\hline BI08 & Mean Temperature of Wettest Quarter \\
\hline BI09 & Mean Temperature of Driest Quarter \\
\hline BI010 & Mean Temperature of Warmest Quarter \\
\hline BI011 & Mean Temperature of Coldest Quarter \\
\hline BI012 & Annual Precipitation \\
\hline
\end{tabular}




\begin{tabular}{|l|l|}
\hline Index & Description \\
\hline BIO13 & Precipitation of Wettest Month \\
\hline BIO14 & Precipitation of Driest Month \\
\hline BI015 & Precipitation Seasonality (Coefficient of Variation) \\
\hline BI016 & Precipitation of Wettest Quarter \\
\hline BI017 & Precipitation of Driest Quarter \\
\hline BI018 & Precipitation of Warmest Quarter \\
\hline BI019 & Precipitation of Coldest Quarter \\
\hline
\end{tabular}

These indices were downloaded for the entire globe from the GCM Downscaled Data Portal. They were derived from the results of the highlighted models in Table 2 for four decadal epochs and for the four representative concentration pathway storylines. These bioclimatic indices are derived from historic global climate data with the goal of identifying what pressures future climate might put on the location and alter these human land use patterns. Therefore, it is possible to project likely locations of biomes and anthromes in the future. 


\section{Statistical Analysis}

All aspects of the analysis were conducted using the R statistical system ${ }^{1}$ and the following associated packages:

- Raster: This is a general purpose GIS suite of functions.

- RStoolbox: This is a set of functions that support raster GIS-based image processing. In the present case, the bioclimatic indices are used in place of remotely sensed images.

- randomForest: The statistical model employed is the random forest model. Random forest models improve how decision trees perform. The algorithm works by starting out with trees, in this case bioclimatic indices, similarly to how a normal decision tree algorithm functions. Each time there is a split, the algorithm uses only a small subset of random features for the split as opposed to using the full set of features. This process continues creating multiple trees and eventually finds the average of all the trees to reach the final model. This occurs by decreasing the correlation between the trees and therefore reducing the variance of the final tree. For the present case, the bioclimatic indices were compared to current locations of biomes and anthromes. Using this method, the model was trained to determine where future biomes and anthromes would be located based on bioclimatic indices.

- doParallel is a package within $\mathrm{R}$ that provides the "parallel backend" for another R package, foreach, which it is necessary to execute the foreach loops in parallel. doParallel uses multicore or snow functionality dependent upon whether it is being run on a Unix-like or Windows system; therefore, its most effective use is on a multiprocessor/multicore computer.

The gross analysis steps were as follows:

1. Obtain base maps for biomes (The Nature Conservancy 2003) and anthromes (Ellis and Ramankutty 2008). These maps are representations of historic biomes and anthromes and serve as a basis to train the statistical model for future climate scenarios.

2. Subselect from all maps the area of interest. For example, this technical report focuses on the following countries in Central America: Belize, El Salvador, Guatemala, Nicaragua, and Honduras.

\footnotetext{
${ }^{1}$ https://www.r-project.org/
} 
3. Develop a statistical model that correlates the obtained historic use of the land (dependent variable) with the bioclimatic indices (independent variable). If a land cover type is too small, it is eliminated because the statistics required for the analysis will be inefficient and is excluded from the analysis. The randomPoints tool within the randomForest package was used to select 30,000 points within the domain of interest to analyze. Of the 30,000 points, 15,000 points were used for model validation while the other 15,000 points were used to train the model for the future projections.

4. Apply the statistical model against all available combinations of the eight climate models shown in Table 2, the four RCP scenarios shown in Table 1, four epochs (2030s, 2050s, 2070s, and 2080s), and five countries, for a total of 640 combinations.

This report focuses on five countries in Central America: Belize, El Salvador, Guatemala, Nicaragua, and Honduras. For the anthrome or biome to be considered in the analysis, at least one of the GCMs per country must have at least $10 \%$ of the total area as that biome or anthrome coverage. A percent range of aerial coverage was given based on the range of values from the GCMs. For example, if the anthrome/biome has a range of $10 \%$ to $20 \%$, that indicates that the smallest amount from a given GCM is 10\% coverage and the highest is $20 \%$, with the other GCMs falling somewhere between $10 \%$ to $20 \%$. Additionally, RCP 2.6 was not examined, as it is likely not to occur given the consistent GHG pattern. Also, the 2070s epoch was left out of the analysis due to the proximity of it with the 2080s. 


\section{Results}

Since anthromes are based loosely on biomes, the results are related; however, there is a distinct difference between the two. Biomes examine patterns in ecosystems and map differences in vegetation based on climate. Anthromes examine those same components as biomes, in addition to how humans interact with the ecosystem (Ellis and Ramankutty 2008).

\subsection{Ecosystem shift pressures}

This first part of the analysis focused on how biomes will be affected by shifting climates in the near and far future. All of the descriptions were taken from the World Wildlife Foundation (WWF 2017) description of ecoregions. The analysis is first broken apart by biome type. Then, within each biome, it is separated by time period. Within each time period, there are three paragraphs, one for each of the RCPs analyzed. This same structure is repeated for the anthrome analysis. Additional information regarding the percentage of landcover and percentage change of landcover for each biome type is located in the Appendix (Table 25 through Table 69).

\subsubsection{Central American Atlantic Moist Forest (Table 25 through Table 27)}

\section{Baseline}

The Central American Atlantic Moist Forest ecoregion represents the classical wet tropical jungle and extends over the lowland Atlantic slopes of southern Nicaragua, Costa Rica, and Panama. This ecoregion is a subset of the tropical and subtropical moist broadleaf forests biome. It was delineated from country-level forest, bird, mammal, and biological zonation maps that date from the 1960 s to the 1990 .

\section{During the 2030s epoch}

For RCP 4.5, Nicaragua has the highest percentage of land cover ranging between $30 \%$ to 50\%. Belize and Honduras have up to $30 \%$ as Central American Atlantic Moist Forest; however, their minimum aeral percentages are $>0 \%$ and $23 \%$, respectively. Guatemala ranges between $3 \%$ to $15 \%$. When compared to historic values, Guatemala and Nicaragua exhibit a range of increases and decreases ranging from a decrease of $60 \%$ 
to increase of $115 \%$ and decrease of $22 \%$ to increase of $40 \%$, respectively. Honduras shows a decrease for all scenarios ranging between $2 \%$ to $30 \%$. Contrarily, Belize has an increase between $700 \%$ to $47,000 \%$ due to small historic values of $0.07 \%$ of the total land cover as Central American Atlantic Moist Forest.

RCP 6.0 shows similar trends as RCP 4.5. Belize and Nicaragua have maximum amounts reach 40\%; however, their minimum values across simulations is $>0 \%$ and $35 \%$, respectively. Honduras remains close to $30 \%$, while Guatemala ranges between $3 \%$ to $20 \%$ across simulations. Honduras and Nicaragua stay near $0 \%$ change when compared to historic values ranging from between decrease of $7 \%$ to increase of $1 \%$ and decrease of $15 \%$ and increase of $10 \%$, respectively. Guatemala also shows increases and decreases; however, they have a higher range between an increase $190 \%$ to decrease $45 \%$. Once again, Belize shows an increase between $105 \%$ to $59,000 \%$ due to small historic values.

RCP 8.5 continues with the trends shown in RCP 6.0 and 4.5. Belize and Nicaragua have scenarios up to $40 \%$ coverage; however, they have minimums of $1 \%$ and $30 \%$, respectively. Guatemala and Honduras stay near their RCP 4.5 and 6.0 amounts, ranging from $5 \%$ to $15 \%$ and $25 \%$ to $33 \%$, respectively. When comparing to their historic values, Honduras decreases for all scenarios ranging from $3 \%$ to $23 \%$; Nicaragua has increases and decreases ranging between decrease of $25 \%$ and increase of 6\%. Guatemala and Belize show increases for all simulations ranging between $3 \%$ to $125 \%$ and $1500 \%$ to $64,000 \%$, respectively.

\section{During the 2050s epoch}

In general, the percentage of land for Central American Atlantic Moist Forest does change drastically compared to the 2030s. Nicaragua has the highest ranging from $35 \%$ to $47 \%$. Belize and Honduras have the maximum range reaching $30 \%$ while the minimums are $1 \%$ and $20 \%$, respectively; Guatemala ranges between $2 \%$ to $12 \%$. Honduras has decreases compared to historic values for all simulations ranging between $5 \%$ to $35 \%$. Nicaragua and Guatemala have some increase and decrease compared to historic values ranging between an increase of $30 \%$ to a decrease of $5 \%$ and an increase of $90 \%$ and decrease of $68 \%$, respectively. Belize shows an increase ranging between $1,300 \%$ to $45,000 \%$ largely due to having an extremely small historic value. 
Once again, RCP 6.0 shows similar trends to RCP 4.5. Nicaragua and Belize have the highest percentages at $40 \%$, with minimums at $30 \%$ and $1 \%$, respectively. Honduras has a range of simulations between $23 \%$ to $35 \%$ while Guatemala is between $2 \%$ to $17 \%$. Similarly to RCP 6.0 for the 2030s epoch, all countries show an increase and decrease compared to historic values, except for Belize. Guatemala has the largest range between an increase of $170 \%$ and decrease of $70 \%$. Honduras and Nicaragua have a small range of change between an increase of $3 \%$ and decrease of $30 \%$, and increase of $13 \%$ and decrease of $15 \%$, respectively. Belize has an increase for all simulations between $1,100 \%$ and $58,000 \%$.

RCP 8.5 shows similar trends as though with RCP 4.5 and RCP 6.0.

Nicaragua has the highest amount ranging between 30\% to $43 \%$, with Belize close ranging between $0 \%$ to $40 \%$. Honduras ranges between $20 \%$ to $32 \%$, and once again Guatemala has the lowest between $1 \%$ to $15 \%$. Compared to historic values, Honduras decreases for all simulations between $5 \%$ to $35 \%$. Similarly to RCP 4.5 and 6.0, Guatemala and Nicaragua show increases and decreases ranging between an increase of $147 \%$ and decrease of $82 \%$, and increase of $17 \%$ and decrease of $20 \%$, respectively. Belize has a range of a $61,000 \%$ increase to a decrease of $100 \%$.

\section{During the 2080s epoch}

The overall percentages for RCP 4.5 remain fairly similar to those in the 2030 and 2050 s epochs. Nicaragua has the highest maximum value at $45 \%$ with low range at $35 \%$. Belize has the widest range between $>0 \%$ to $40 \%$. Honduras ranges between $20 \%$ to $35 \%$, while Guatemala is between $1 \%$ to $15 \%$. Nicaragua is the only country to not show a percent decrease when compared to historic values and has a range between a $20 \%$ increase and no increase. Honduras, Guatemala, and Belize show percent increase and decrease ranging between increase of $6 \%$ decrease of $35 \%$, increase of $155 \%$ decrease of $90 \%$, and increase of $68,000 \%$ and decrease of $90 \%$, respectively.

Compared to the 2030s and 2050s epoch, the range between the high and low values is slightly larger for the 2080s for RCP 6.o. Belize and Guatemala have the low part of their range at $1 \%$ with maximums up to $53 \%$ and $18 \%$, respectively. Honduras ranges between $22 \%$ to $30 \%$, while Nicaragua is between $30 \%$ to $47 \%$. Honduras shows a decrease for all simulations ranging between $6 \%$ to $32 \%$. Guatemala and Nicaragua have increases and decreases compared to historical values. Guatemala ranges 
between a $180 \%$ increase to $80 \%$ decrease, while Nicaragua ranges between a $28 \%$ increase and $15 \%$ decrease. Belize increases for all simulations ranging between $890 \%$ and $79,000 \%$.

RCP 8.5 for the 2080 epoch remained similar to those values from the 2030 and 2050 s epochs. Belize had the greatest range between $0 \%$ to $40 \%$; however, Nicaragua had the highest value at $47 \%$ with a minimum at $30 \%$. Honduras ranges between $17 \%$ to $30 \%$, and Guatemala has the smallest amount ranging between $1 \%$ to $15 \%$. Honduras shows decreases for all simulations ranging between $13 \%$ to $45 \%$ compared to historic values. Once again, Guatemala and Nicaragua have increases and decreases compared to historic values ranging from an increase of $140 \%$ to decrease of $80 \%$ and increase of $30 \%$ to decrease of $15 \%$, respectively. Belize ranges from an increase of $61,000 \%$ to $100 \%$ decrease.

\subsubsection{Isthmian-Atlantic Moist Forests (Table 28 through Table 30)}

\section{Baseline}

The Isthmian-Atlantic Moist Forest biome is the epitome of a wet, tropical jungle located where Central and South America meet, specifically northern Costa Rica, southern Nicaragua, and most of Panama. This ecoregion is a subset of the tropical and subtropical moist broadleaf forests biome and evolved from combinations of flora and fauna from North and South America. This ecoregion was delineated from two different national vegetation maps from the late 1960 s and early 1970 .

Nicaragua was the only country to meet the minimum $10 \%$ requirement to be analyzed for all epochs and RCPs.

\section{During the 2030s epoch}

For RCP 4.5, 6.0, and 8.5, Nicaragua has approximately $10 \%$ to $20 \%$ as Isthmian-Atlantic Moist Forest. When comparing to historical values, there is wide range in percent difference ranging from a decrease of $45 \%$ to an increase of $25 \%$.

\section{During the 2050s epoch}

Compared to the 2030 s epoch, the differences between the climate scenarios become more pronounced. RCP 6.0 remains fairly consistent with the 2030 s values ranging between $10 \%$ to $20 \%$. RCP 4.5 and 8.5 have 
minimum values at $5 \%$, but have maximums at $13 \%$ and $18 \%$, respectively. When compared to historic values, RCP 4.5 has percent decrease for simulations when compared to historic values ranging between $18 \%$ to $65 \%$. RCP 6.0 and 8.5 have percent increase and decrease ranging between increase of $8 \%$ to decrease of $45 \%$ and increase of $15 \%$ to decrease of $70 \%$, respectively.

\section{During the 2080s epoch}

The coverage of Isthmian-Atlantic Moist Forests decreased for all climate scenarios compared to the 2030 s epoch: RCP 4.5, 3\% to 13\%; RCP 6.0, 7\% to $17 \%$; RCP $8.5,1 \%$ to $18 \%$. When compared to historic values, RCP 4.5 once again decreases for all climate scenarios ranging between $15 \%$ to $78 \%$. RCP 6.0 and 8.5 have higher simulations with higher amounts of decrease and those with increase are less; these ranges are between increase $5 \%$ and decrease of $53 \%$ and increase of $15 \%$ and decrease of $90 \%$, respectively.

\subsubsection{Pantanos de Centla (Table 31 through Table 33)}

\section{Baseline}

The Panatanos de Centla ecoregion consists of a mixture of riparian habitats, moist forests, and wetlands. The soils are fertile; therefore, the region is dominated by agriculture. This ecoregion is a subset of the tropical and subtropical moist broadleaf forests biome. The delineation of the ecoregion was developed from experts during workshops in the mid-199os.

During the historic time period, none of the countries had any land as Pantanos De Centla; therefore, all countries, climate projections, and epochs are an increase from 0 .

During the 2030s epoch

For RCP 4.5, Belize had a range in simulations between $2 \%$ to $25 \%$, and Guatemala was very similar between $7 \%$ to $20 \%$. Compared to RCP 4.5 , for RCP 6.o, both countries had a slightly larger range between the minimum and maximum with Belize between $>0 \%$ to $30 \%$ and Guatemala between $3 \%$ to $20 \%$. Belize maintained the same range for RCP 8.5 at $>0 \%$ to $30 \%$, while Guatemala reduced its range to $8 \%$ to $15 \%$. 
During the 2050s epoch

Similarly to the 2030s, Belize and Guatemala have at least $10 \%$ of their land as Pantanos De Centla; Belize ranges from 3\% to 40\% for RCP 4.5 while Guatemala ranges between $8 \%$ to $23 \%$. For RCP 6.0, they remain close to the RCP 4.5 levels with Belize between $3 \%$ to $38 \%$ and Guatemala between $10 \%$ to $25 \%$. However, for RCP 8.5 , Honduras also has at least $10 \%$ for one simulation with a range in area between $0 \%$ to $10 \%$. Guatemala remains near its amounts for RCP 4.5 and RCP 6.0 between 8\% to $27 \%$; however, Belize increases and ranges between $>0 \%$ to $48 \%$.

During the 2080s epoch

Compared to the $\mathrm{RCP} 4.5$ range for the 2030 and 2050s, the range is higher for the 2080 s for Belize at $10 \%$ to $48 \%$. Guatemala is similar, maybe slightly higher than the previous epochs at $12 \%$ to $25 \%$. Belize remained at very similar levels for RCP 6.0 between $7 \%$ to $48 \%$. Guatemala stayed fairly close between $5-30 \%$, and Honduras ranged between $0 \%$ to $15 \%$. Belize had a large jump for RCP 8.5, up to $68 \%$ for the max and $1 \%$ for the minimum. Guatemala and Honduras remained fairly similar for RCP 8.5 at $10 \%$ to $32 \%$ and $>0 \%$ to $22 \%$, respectively.

\subsubsection{Southern Pacific Dry Forests (Table 34 through Table 36)}

\section{Baseline}

The Southern Pacific Dry Forests are located on the southeastern slopes of the Sierra Madre del Sur Mountains leading to a small amount of coastal plains where the ecoregion occurs. This ecoregion is a subset of the tropical and subtropical dry broadleaf forests biome. The dry season is fairly lengthy; hence, the vegetation is largely deciduous. The delineation for this ecoregion is based on linework from current land cover classifications of National Institute of Statistics and Geography (INEGI), combining the following classifications: evergreen middle elevation forest, evergreen lowland forest, patches of savanna, and all agriculture activity. Modification from experts occurred later at workshops in the $1990 \mathrm{os}$

\section{During the 2030s epoch}

None of the countries met the minimum 10\% threshold to be analyzed. 
During the 2050s epoch

Nicaragua ranged between $\mathrm{O} \%$ to $12 \%$ for $\mathrm{RCP} 4.5$, which is an increase compared to the historic value of 0 .

During the 2080s epoch

Once again for RCP 4.5, Nicaragua met the minimum requirement and ranged between $0 \%$ to $12 \%$ compared to $0 \%$ for the historic value. For RCP 8.5, El Salvador ranged between o\% to 25\% and also had o\% for the historic time period. Guatemala ranged between $3 \%$ to $10 \%$, which is an increase between $240 \%$ to $1,200 \%$, compared to the small historic amount.

\subsubsection{Neotropic (Table 37 through Table 39)}

\section{Baseline}

The Neotropic ecoregion is found throughout Central America. It is largely composed of tropical rainforests.

Nicaragua is the only country to reach the minimum $10 \%$ threshold to be analyzed for the Neotropic biome.

During the 2030s epoch

In general, the amount of the Neotropic biome stayed fairly consistent between the different climate scenarios. Most of the simulations for RCP 4.5 stayed at approximately 10\% while RCP 6.0 and 8.5 had slightly larger ranges, between $5 \%$ to $12 \%$ and $7 \%$ to $13 \%$. Compared to historic values, RCP 4.5 increased for all simulations ranging between an increase of $15 \%$ to $57 \%$. The only climate scenario to show a decrease was RCP 6.0 ranging between a decrease of $17 \%$ to an increase of $70 \%$ RCP 8.5 ranged between an increase of $82 \%$ to remaining the same as the historic value.

\section{During the 2050s epoch}

All of the climate scenarios ranged approximately between $5 \%$ to $15 \%$, with RCP 4.5, and 6.o being slightly lower on the high end than RCP 8.5. RCP 4.5 has the closest range in comparison to the minimum and maximum difference from historic values ranging from an increase of $70 \%$ to a decrease of $43 \%$; RCP 6.0 ranges between a decrease of $15 \%$ and increase of $85 \%$ while RCP 8.5 is between a decrease of $25 \%$ to an increase of $98 \%$. 
During the 2080s epoch

The simulations remain moderately close with RCP 4.5 ranging between

$3 \%$ to $12 \%$, RCP 6.0 between $8 \%$ to $12 \%$, and RCP 8.5 between $3 \%$ to $13 \%$.

Since the ranges are fairly close together, the percent difference compared to historic values are also close together in range. RCP 4.5 ranges from a decrease of $65 \%$ to an increase of $70 \%$. RCP 6.0 increases for all simulations ranging between an increase of $5 \%$ up to $80 \%$. However, RCP 8.5 is similar to RCP 4.5 and is between a decrease of $47 \%$ to an increase of $82 \%$.

\subsubsection{Petén-Veracruz Moist Forest (Table 40 through Table 42)}

\section{Baseline}

The Petén-Veracruz Moist Forest ecoregion is representative of the mix of wetlands, moist forests, and riparian habitats located in the northern portion of Central America. This ecoregion is a subset of the tropical and subtropical moist broadleaf forests biome. The soils are very rich, and there are a wide variety of species. This wetland ecoregion is delineated from expert opinion during workshops in the 1990s.

\section{During the 2030s epoch}

Historically, Belize is predominantly Petén-Veracruz Moist Forest consisting of approximately $87 \%$ of its land. When looking at RCP 4.5 , this amount drops to $25 \%$ to $0 \%$. Guatemala has a similar amount for the low range at $25 \%$, but its maximum reaches only $40 \%$. Honduras ranges from $2 \%$ to $17 \%$. Compared to historic levels, Belize and Guatemala decrease for all simulations ranging between a decrease of $33 \%$ to $70 \%$ and $13 \%$ to $47 \%$ decrease, respectively. Honduras has an increase of $1,100 \%$ to $8,900 \%$, but that is largely due to an extremely small historic value of $0.19 \%$.

Compared to the RCP 4.5 values, the countries remain fairly similar for the RCP 6.0 values. Belize remains the highest at 25\% to $80 \%$. Guatemala ranges between $15 \%$ to $42 \%$, while Honduras is at $>0 \%$ to $15 \%$. Compared to historic values, Belize and Guatemala have a decrease ranging between $7 \%$ to $68 \%$. Once again Honduras exhibits an increase ranging between $250 \%$ to $8,300 \%$.

With RCP 8.5, unlike the other climate scenarios, the countries are fairly close in the amount of Petén-Veracruz Moist Forest. Belize ranges between 
$25 \%$ to $35 \%$, and Guatemala is similar at $20 \%$ to $25 \%$. Honduras is slightly smaller ranging between $>0 \%$ to $22 \%$. Belize has the largest decrease from historic values at $60 \%$ to $70 \%$ decrease; Guatemala is at $42 \%$ to $55 \%$ decrease. Honduras increases between $180 \%$ to $12,000 \%$.

\section{During the 2050s epoch}

Belize and Guatemala have minimums at $20 \%$ for RCP 4.5 with maximums of $47 \%$ and $30 \%$, respectively. Honduras ranges between $5 \%$ to $22 \%$. Once again due to small historic values for Honduras, the percent difference increases $2,600 \%$ to $12,000 \%$. Belize decreases from historic values $45 \%$ to $77 \%$ and Guatemala decreases $35 \%$ to $55 \%$.

The amount of Petén-Veracruz Moist Forest stays consistent from RCP 4.5 to RCP 6.o. Belize remains the highest ranging between $22 \%$ to $50 \%$ with Guatemala close at $15 \%$ to $30 \%$. Honduras ranges between $>0 \%$ to $20 \%$. Once again Belize has the highest decrease from historic value with a decrease of $42 \%$ to $75 \%$. Guatemala also has a fairly large decrease ranging between $30 \%$ to $67 \%$. Honduras increases between $330 \%$ to $10,000 \%$.

With RCP 8.5, Guatemala's maximum percentage of $27 \%$ surpassed Belize's maximum percentage of $25 \%$; their minimums are $17 \%$ and $15 \%$, respectively. Honduras ranges between $1 \%$ to $15 \%$. Compared to the 2030 s epoch, the decrease for Belize is more substantial ranging between $73 \%$ to $83 \%$. Guatemala has a decrease between $40 \%$ to $63 \%$. Once again, Honduras has an increase between $470 \%$ to $8500 \%$.

\section{During the 2080s epoch}

Compared to the 2030s and 2050s epoch, Belize and Guatemala have a decrease for RCP 4.5 ranging between $12 \%$ to $40 \%$ and $10 \%$ to $30 \%$, respectively. Honduras stays fairly consistent compared to the previous epoch, at $5 \%$ to $20 \%$. Compared to historic values, Belize and Guatemala see fairly substantial decreases, especially on the high end of the climate simulations ranging from $55 \%$ to $85 \%$ and $37 \%$ to $75 \%$ decreases, respectively. Honduras increases for all simulations between $280 \%$ to $11,000 \%$.

Similarly to RCP 4.5, for RCP 6.o Belize and Guatemala see a substantial decrease compared to previous epochs; Belize ranges between 10\% to 35\% and Guatemala is between $15 \%$ to $25 \%$. Contrarily, Honduras increases 
throughout time with a range between $3 \%$ to $25 \%$. Once again, compared to historic values, Belize and Guatemala have large decreases ranging between $60 \%$ to $87 \%$ and $45 \%$ to $65 \%$, respectively. Honduras has an increase of $1,500 \%$ to $13,000 \%$, due to very small historic amounts.

Following the pattern from the 2050s for RCP 8.5, Guatemala has more Petén-Veracruz Moist Forest at $17 \%$ to $22 \%$ than Belize at 3\% to $15 \%$. Honduras also surpasses Belize at $5 \%$ to $20 \%$. Belize has an enormous decrease compared to historic levels ranging between $80 \%$ to $97 \%$. Guatemala also decreases 50\% to 65\%, while Honduras increases 2,000\% to $10,000 \%$.

\subsubsection{Sierra Madre De Chiapas Moist Forest (Table 43 through Table 45)}

\section{Baseline}

The Sierra Madre De Chiapas Moist Forest ecoregion is rich with species and is located at the base of the Sierra Madre of Chiapas Mountains, which are in Mexico, El Salvador, and Guatemala. This ecoregion is a subset of the tropical and subtropical moist broadleaf forests biome. The delineation for this region is derived from numerous vegetation maps for Guatemala, Mexico, and El Salvador and modified by expert review.

During the 2030s epoch

Even though El Salvador had a small historic amount of Sierra Madre De Chiapas Moist Forest biome, with RCP 8.5, the amount ranged between $0 \%$ to $13 \%$. Compared historically, this is a change ranging between an increase of $635 \%$ to a decrease of $100 \%$.

During the 2050s epoch

None of the countries meet the minimum threshold to be analyzed.

During the 2080s epoch

Similarly to the 2030 s epoch, El Salvador ranges between $>0 \%$ to $15 \%$ for $\mathrm{RCP} 8.5$. This is a change ranging from an increase of $680 \%$ to a decrease of $99 \%$ compared to historic values. 


\subsubsection{Veracruz Moist Forests (Table 46 through Table 48)}

Baseline

The Veracuz Moist Forest ecoregion encompasses lowlands and is situated in a tropical humid climate with a rainy season and minimal temperature oscillations located near the Gulf of Mexico. This ecoregion is a subset of the tropical and subtropical moist broadleaf forests biome. Unfortunately, very little of this biome remains. This ecoregion was derived from the INEGI land cover maps with linework modified by experts during meetings in the 1990 s.

\section{During the 2030s and 2050s epoch}

For these epochs there were no countries that met the minimum threshold to be analyzed.

During the 2080s

Guatemala increased from a historic level o to a range between o\% to $15 \%$ across the climate simulations of RCP 8.5.

\subsubsection{Yucatán Moist Forests (Table 49 through Table 51)}

\section{Baseline}

The Yucatán Moist Forest ecoregion represents a humid tropical climate with minimal topographic relief. This biome is an important biological corridor between moist forests of Central America and the northern Yucatán Peninsula. This ecoregion is a subset of the tropical and subtropical moist broadleaf forests biome. This ecoregion was derived from the INEGI land cover maps by combining several forest type classifications and human modified land covers to encompass historical coverage. Linework was modified by experts during meetings in the 1990 .

\section{During the 2030s epoch}

Belize ranges between $0 \%$ to $10 \%$ for $\mathrm{RCP} 4.5$. This ranges between an increase of $650 \%$ to a decrease of $100 \%$ compared to historic values. 
During the 2050s and 2080s epoch

No countries during these epochs met the minimum threshold requirement.

\subsubsection{Central American Dry Forests (Table 52 through Table 54)}

\section{Baseline}

The Central American Dry Forest stretches along the Pacific coast including parts of southwestern Mexico, El Salvador, Nicaragua, Guatemala, Honduras, and northwestern Coast Rica; it is representative of a tropical habitat that has a dry season of 5-8 months. This ecoregion is a subset of the tropical and subtropical dry broadleaf forests biome. The delineation of this ecoregion was derived from a variety of maps with the final linework results from experts at workshops in the 1990s.

\section{During the 2030s epoch}

Many of the countries have Central American Dry Forest biome. Guatemala has the smallest range between $7 \%$ to $10 \%$ for RCP 4.5 . Honduras and Nicaragua have maximums at $25 \%$ with minimum values at $10 \%$ and $18 \%$, respectively. El Salvador is the highest at $55 \%$ to $63 \%$. Compared to historic values, El Salvador increases for all simulations ranging between $50 \%$ to $73 \%$. Guatemala, Honduras, and Nicaragua have climate simulations that increase and decrease with a range of increase of $48 \%$ to decrease of $7 \%$, increase of $70 \%$ to decrease of $25 \%$, and increase of $22 \%$ to decrease of $7 \%$, respectively.

For RCP 6.0, most of the biome area remains very similar to that of RCP 4.5. El Salvador still has the most with the range between 50\% to $68 \%$. Nicaragua and Honduras are very similar with ranges between $18 \%$ to $25 \%$ and $15 \%$ to $23 \%$, respectively. Guatemala once again has the smallest amount at approximately $10 \%$. Compared to historic values, Guatemala and El Salvador increase for all climate simulations with a range of increase between $13 \%$ to $57 \%$ and $40 \%$ to $85 \%$, respectively. Honduras increased up to $60 \%$ and had no decreasing with a minimum value of $0 \%$ change. Nicaragua had increasing and decreasing climate simulations ranging between an increase of $22 \%$ and a decrease of $8 \%$.

Guatemala remains similar in RCP 8.5 at approximately $10 \%$ across all simulations. Honduras and Nicaragua have maximums at 25\% again with 
minimums at $15 \%$ and $18 \%$, respectively. El Salvador increases with a range of $53 \%$ to $75 \%$ and also has the highest increase compared to historic values ranging between $45 \%$ to $100 \%$ increase. Guatemala also increases across all simulations between $6 \%$ to $53 \%$. Honduras and Nicaragua have simulations showing increases and decreases ranging between an increase of $75 \%$ to decrease of $7 \%$ and increase of $25 \%$ to decrease of $10 \%$, respectively.

During the 2050s epoch

Compared to the RCP 4.52030 s epoch, the amount of Central American Dry Forest remains fairly similar. El Salvador has the most at $55 \%$ to $70 \%$. Nicaragua ranges between $18 \%$ to $28 \%$, and Honduras is very close at $10 \%$ to $22 \%$. Guatemala is the smallest approximately at $7 \%$ to $10 \%$. Once again, El Salvador has the largest change with an increase between $50 \%$ to $97 \%$. Guatemala and Nicaragua have decreases of approximately $8 \%$ with increases up to $53 \%$ and $40 \%$, respectively. Honduras ranges between an increase of $55 \%$ and decrease of $28 \%$.

Looking at RCP 6.0, Guatemala had very consistent output from the climate simulations, all agreeing at approximately $10 \%$. Similarly to RCP 4.5, Honduras and Nicaragua remain fairly close ranging between $15 \%$ to $23 \%$ and $18 \%$ to $27 \%$, respectively. El Salvador continues to have the highest amount between $55 \%$ to $73 \%$. Looking at historic amounts for comparison, El Salvador continues to have the largest percentage change between a $55 \%$ to $100 \%$ increase. Guatemala also increases for all simulations between $6 \%$ to $60 \%$. Honduras and Nicaragua decrease slightly and increase ranging between a decrease of $3 \%$ and increase of $60 \%$ and decrease of $8 \%$ and increase of $37 \%$, respectively.

For RCP 8.5, all countries have increased their maximum range compared to the simulations for RCP 4.5 and RCP 6.0. Honduras is the only country to have the minimum lower than RCP 4.5 and 6.0 minimums at $5 \%$ minimum. Honduras and Nicaragua have maximums at $30 \%$, with Nicaragua having a minimum at 20\%. El Salvador remains the highest amount between $60 \%$ to $78 \%$ and also has the highest percentage increase compared to historic values at $60 \%$ to $115 \%$. Honduras also has a large percentage increase at $110 \%$ ranging to a decrease of $63 \%$. Nicaragua and Guatemala are fairly close with percentage differences of $60 \%$ increase to $5 \%$ decrease and $80 \%$ increase to $11 \%$ decrease. 
During the 2080s epoch

As with the previous epochs, for RCP 4.5 El Salvador is dominated by Central American Dry Forests with a range of between 53\% to 70\%;

Nicaragua has $17 \%$ to $30 \%$ while Honduras has $15 \%$ to $20 \%$ of Central American Dry Forest. Guatemala has the smallest amount at $7 \%$ to $12 \%$ and had no decreases compared to historic values with a range of $72 \%$ increase to no change. Similarly, El Salvador increased for all climate simulations between $45 \%$ to $90 \%$ compared to historic values. Honduras and Nicaragua ranged from small decreases to increases at a decrease of $4 \%$ to increase of $42 \%$ and decrease of $10 \%$ to increase of $46 \%$, respectively.

El Salvador remained very similar to RCP 4.5 for RCP 6.0 at $50 \%$ to $70 \%$ Central American Dry Forest coverage. Guatemala was very consistent amongst the simulations with all of it being approximately $10 \%$. Honduras ranged between $8 \%$ to $28 \%$ while Nicaragua was slightly higher at $18 \%$ to 30\%. El Salvador and Guatemala increased for all simulations ranging between $40 \%$ to $90 \%$ and $25 \%$ to $65 \%$, respectively. Nicaragua had increases up to $50 \%$ and decreases down to $8 \%$. Honduras had the largest range, ranging between an increase of $93 \%$ to a decrease of $45 \%$.

For RCP 8.5, Guatemala remained the same at approximately 10\% coverage of Central American Dry Forests for all simulations. Honduras and Nicaragua stayed close to the RCP 6.0 levels at $3 \%$ to $27 \%$ and $18 \%$ to $35 \%$, respectively. Once again, El Salvador had the highest amount at $25 \%$ to $65 \%$. Compared to historic values, Guatemala was the only country to not have any decrease and had a range of increase between $18 \%$ to $67 \%$. Honduras had the largest range, between an increase of $90 \%$ and a decrease of $83 \%$. Nicaragua ranged between an increase of $75 \%$ and decrease of $5 \%$, and El Salvador ranged between an increase of $80 \%$ and decrease of $33 \%$.

\subsubsection{Yucatán Dry Forests (Table 55 through Table 57)}

\section{Baseline}

The Yucatán Dry Forest ecoregion is located in the northwest section of the Yucatán peninsula and is dominated by flat terrain and low amounts of precipitation. This ecoregion is a subset of the tropical and subtropical dry broadleaf forests biome. The delineation of this ecoregion is from vegetation cover maps grouping the following classifications: grasslands, 
low deciduous forest, medium deciduous forest, microphyll desert matorral, in addition to other agriculture within this classification; linework was reviewed at ecoregional workshops in the 1990s.

During the 2030s epoch

None of the countries met the minimum 10\% threshold to be analyzed.

During the 2050s epoch

Honduras was the only country to meet the minimum area requirement. For RCP 4.5, it had between $>0 \%$ to $10 \%$, and for RCP 8.5 it ranged between $>0 \%$ to $15 \%$; it did not meet the minimum requirement for RCP 6.0, and therefore it was not analyzed. Due to extremely small historic amounts, the percent difference between future simulation and history is large, with RCP 4.5 having an increase between $71,000 \%$ to $137,0000 \%$, and RCP 8.5 increase between $104,000 \%$ to $190,0000 \%$.

During the 2080s epoch

Belize and Honduras met the minimum threshold requirements for analysis; however, this time Honduras met the requirements for all three climate scenarios. RCP 4.5 and 6.0 have approximately the same amount for Honduras at $1 \%$ to $15 \%$. For RCP 8.5, Honduras increased to a range of $5 \%$ to $30 \%$ while Belize ranges between $0 \%$ to $13 \%$, which is an increase from $0 \%$ during the historic period. For Honduras, once again the small historic value causes a huge increase with ranges between $76,000 \%$ to $220,0000 \%, 153,000 \%$ to $211,0000 \%$ and $621,000 \%$ to $410,0000 \%$ for RCP 4.5, 6.0, and 8.5, respectively.

\subsubsection{Central American Pine-Oak Forests (Table 58 through Table 60)}

Baseline

The Central American Pine-Oak Forests ecoregion is located in parts of Mexico, most of Honduras and El Salvador, southern Guatemala, and a small amount of west-central Nicaragua. This ecoregion is a subset of tropical and subtropical coniferous forests biome. The delineation for this ecoregion is based on regional maps with additional elevation data due to historic ranges being unknown. 
During the 2030s epoch

For RCP 4.5, Guatemala, Honduras, and El Salvador have approximately the same amount of land with ranges between $20 \%$ to $27 \%$, 20\% to $30 \%$, and $25 \%$ to $35 \%$. Compared to historic values, all have decreasing amounts. Guatemala decreases $7 \%$ to $28 \%$ while Honduras decreases $23 \%$ to $48 \%$. $\mathrm{El}$ Salvador has the highest decrease ranging between $40 \%$ to $58 \%$.

RCP 6.0 overall is similar to RCP 4.5. All of the simulations for Guatemala are approximately the same at $25 \%$. Honduras has similar amounts ranging between $20 \%$ to $32 \%$ while El Salvador has higher amounts at $22 \%$ to $43 \%$. Once again, all simulations are less than the amounts during the historic time period. Guatemala has the smallest decrease from historic levels with a decrease ranging between $5 \%$ to $20 \%$. Honduras and El Salvador have approximately the same amount of the decrease ranging between $25 \%$ to $55 \%$ decrease and $28 \%$ to $62 \%$ decrease, respectively.

Guatemala remains at approximately $25 \%$ for RCP 8.5 . Honduras also remains at similar levels for RCP 8.5 compared to RCP 6.0 at $15 \%$ to $32 \%$. El Salvador is at approximately $20 \%$ to $37 \%$ of Central American Pine-Oak Forests. When compared to historic values, El Salvador had the highest decrease at $37 \%$ to $67 \%$; however, Honduras was close at a $23 \%$ to $65 \%$ decrease. Guatemala also decreased, but only $8 \%$ to $18 \%$.

During the 2050s epoch

Compared to the 2030s epoch, all of the countries exhibit a slight decrease in the amount of Central American Pine-Oak Forests. Honduras and El Salvador have minimums at $10 \%$ with maximums at approximately $30 \%$. Guatemala is also close ranging between $15 \%$ to $25 \%$. Compared to historic values, Guatemala has the lowest amount of decrease ranging between $15 \%$ to $43 \%$. Honduras decreases between $32 \%$ to $75 \%$ while El Salvador decreases $50 \%$ to $80 \%$.

RCP 6.0 values are slightly larger than RCP 4.5 values. Honduras and El Salvador range between $15 \%$ to $33 \%$ while Guatemala is between $20 \%$ to $25 \%$. Once again, Guatemala has the smallest decrease at $10 \%$ to $30 \%$. El Salvador has the highest decrease between $45 \%$ to $75 \%$ and Honduras at $23 \%$ to $68 \%$. 
For RCP 8.5, Guatemala and Honduras have maximums at 25\% with minimums at $15 \%$ and $5 \%$, respectively. El Salvador has very similar values between $5 \%$ to $20 \%$. Keeping with the trend, El Salvador has the largest decrease between $67 \%$ to $92 \%$ compared to historic values. Honduras has the largest range of minimum and maximum decreases ranging between $37 \%$ to $85 \%$ while Guatemala decreases only $18 \%$ to $45 \%$.

\section{During the 2080s epoch}

Guatemala stayed fairly consistent with the other epochs' RCP 4.5 simulations with a range of $20 \%$ to $25 \%$ for the 2080 s. Honduras and El Salvador have smaller amounts compared to previous epochs with ranges between $8 \%$ to $27 \%$ and $7 \%$ to $30 \%$, respectively. El Salvador and Honduras have fairly substantial decreases of $50 \%$ to $87 \%$ and $35 \%$ to $80 \%$, respectively. Guatemala also decreases, but only $12 \%$ to $40 \%$.

Compared to RCP 4.5, for RCP 6.0 El Salvador decreases to 6\% to $15 \%$. Honduras and Guatemala remained fairly consistent at $5 \%$ to $25 \%$ and approximately 20\%, respectively. Once again El Salvador and Honduras have large decreases of $75 \%$ to $90 \%$ and $37 \%$ to $85 \%$, respectively. Guatemala also decreases approximately $25 \%$ to $40 \%$.

For RCP 8.5, El Salvador no longer meets the 10\% minimum requirement for analysis. Guatemala has approximately $10 \%$ to $18 \%$ as Central American Pine-Oak Forests; Honduras has 1\% to $15 \%$. Both have substantial decreases from historic values with a decrease of $38 \%$ to $67 \%$ for Guatemala and $63 \%$ to $97 \%$ for Honduras.

\subsubsection{Miskito Pine Forests (Table 61 through Table 63)}

\section{Baseline}

The Miskito Pine Forests ecoregion is located on the Caribbean coast including the lowlands of Honduras and Nicaragua. This ecoregion is a subset of the tropical and subtropical coniferous forest biome. These forests are distinguishable from surrounding forested area due to the unique species inhabiting the area. The delineation follows Sutton (1988) for Nicaragua and Brown et al. (1998) for Honduras.

Nicaragua is the only country to meet the minimum $10 \%$ threshold to be analyzed. 
During the 2030s epoch

Nicaragua ranged between $4 \%$ to $13 \%$ across the different climate simulations for RCP 4.5. For RCP 6.0 and 8.5, the simulations showed approximately $10 \%$ of the land as Miskito Pine Forests. Compared to historic values, all three climate scenarios have some simulations that increase and some that decrease. RCP 4.5 has the largest range between an increase of $40 \%$ to a decrease of $63 \%$. RCP 6.0 and 8.5 have similar ranges with increases of approximately $25 \%$ to $33 \%$ ranging to decreases of $2 \%$ to $7 \%$.

During the 2050s epoch

The maximum values for all three climate scenarios is approximately $13 \%$ while the minimum values are $2 \%$ for RCP 4.5 and $8 \%$ for RCP 6.0 and 8.5. Similarly, RCP 4.5 has the largest range in change from historic values ranging between an increase in $25 \%$ to a decrease of $78 \%$. RCP 6.0 and RCP 8.5 range between an increase of $30 \%$ to $33 \%$ to a decrease of $17 \%$ to $22 \%$, respectively.

\section{During the 2080s epoch}

By the 2080s, Nicaragua no longer met the minimum threshold for analysis for RCP 8.5. RCP 4.5 had a range between $>0 \%$ to $10 \%$, which compared to historic values is a percent difference ranging between an increase of $15 \%$ and decrease of $95 \%$. For RCP 6.0, Nicaragua had between $5 \%$ to $12 \%$ as Miskito Pine Forests, which is between a $28 \%$ increase to a $50 \%$ decrease compared to historic values.

\subsubsection{Mesoamerican Gulf-Caribbean Mangroves (Table 64 through Table} 66)

\section{Baseline}

The Mesoamerican Gulf-Caribbean Mangroves ecoregion was found in areas of large shallow water, which is critical for its ecological productivity. This ecoregion is a subset of the mangrove biome. Its delineation is the result of a mangrove ecoregion workshop and follow-up report. 
During the 2030s epoch

Belize was the only country during the 2030 s to reach the $10 \%$ minimum to be analyzed. For RCP 4.5, it ranged between 20\% to 48\%, RCP $6.015 \%$ to $40 \%$, and RCP $8.518 \%$ to $48 \%$. Compared to historic values, these are fairly substantial increases. RCP 4.5 had the largest increase with an increase of $130 \%$ to $460 \%$. However, RCP 8.5 was close with an increase of $110 \%$ to $450 \%$, and RCP 6.0 had an increase of $75 \%$ to $390 \%$.

During the 2050s epoch

Once again, Belize was the only country to meet the minimum 10\% threshold to be analyzed. For RCP 4.5, the values remain very similar to those of the 2030 s epoch at $20 \%$ to $45 \%$. RCP 6.0 and RCP 8.5 saw slight increases from the previous epoch at $22 \%$ to $45 \%$ and $23 \%$ to $62 \%$, respectively. All climate scenario simulations have an increase compared to the historic amounts. RCP 4.5 had the least amount of increase ranging between $160 \%$ to $420 \%$, and RCP 6.0 was very close at $160 \%$ to $440 \%$ increase. RCP 8.5 had the largest amount of increase and the widest range at $170 \%$ to $630 \%$ increase from historic levels.

\section{During the 2080s epoch}

As with the previous epochs, Belize meets the minimum threshold for analysis for all scenarios. However, Guatemala also reaches the threshold for RCP 8.5. Compared to the previous epochs for RCP 4.5, the amount decreased slightly at $15 \%$ to $43 \%$. Contrarily, the amount for RCP 6.0 has risen slightly through the epochs and is at $27 \%$ to $55 \%$. For RCP 8.5, Belize has $23 \%$ to $38 \%$ while Guatemala has $3 \%$ to $10 \%$. Percent differences for RCP 4.5 range between an increase of $85 \%$ to $400 \%$. RCP 6.0 values increased from the previous epoch up to an increase of $220 \%$ to $560 \%$. Guatemala has a fairly substantial increase from historic values for RCP 8.5, largely due to starting with a small amount, with a percent increase between $1,400 \%$ to $5,200 \%$; Belize has an increase between $180 \%$ to $340 \%$. 


\subsubsection{Southern Mesoamerican Pacific Mangroves (Table 67 through Table 69)}

\section{Baseline}

The Southern Mesoamerican Pacific Mangroves are located on the Pacific coast of Guatemala, El Salvador, Honduras, Nicaragua, Costa Rica, and parts of Panama. This ecoregion is part of the mangrove biome.

\section{During the 2030s epoch}

The only country to meet the minimum threshold for this analysis was El Salvador for RCP 8.5. It had a range of $4 \%$ to $15 \%$, which is an increase from historic values of $2,900 \%$ to $9,300 \%$, due to a small historic amount.

\section{During the 2050s epoch}

Once again El Salvador is the only country to meet the minimum threshold; however, this time it is met for all climate scenarios. For RCP 4.5 , El Salvador ranges between $4 \%$ to $25 \%$. RCP 6.0 has a slight decrease at $5 \%$ to $15 \%$ while RCP 8.5 has a slight increase at $10 \%$ to $30 \%$. When compared to historic values all simulations have a substantial increase due to small historic values. For RCP 4.5, there is an increase of $2,700 \%$ to $16,000 \%$; RCP 6.0 increases 3,200\% to 9,500\%, and RCP 8.5 is at 7,200\% to $20,000 \%$ increase.

\section{During the 2080s epoch}

A similar pattern continues with El Salvador being the only country to be analyzed. Once again, RCP 4.5 has approximately 5\% to 30\% Southern Mesoamerican Pacific Mangroves. Compared to the 2050s epoch, RCP 6.0 increases up to $10 \%$ to $33 \%$ for the 2080 s. RCP 8.5 has a fairly consistent (compared with previous epochs) minimum at 15\%; however, the maximum is at $72 \%$. Percent difference from historic values showing an increase for all simulations are once again fairly large: RCP 4.5, 3,300\% to 21,000\%; RCP 6.0, 6,300\% to 22,000\%; RCP 8.5, 6,800\% to 50,000\%.

\subsection{Human shift pressures}

Up to this point, the investigation has centered on how biomes might begin to respond to changing climatology. The next focus is to examine the potential effect of shifting climates on anthromes. This analysis is 
only valid to the extent that it can be presumed that societal groups in a location of interest make a living directly off the land; where urban centers, extraction industries, and/or transportation corridors dominate the economy, climate shifts may not be a driver of any changing land use practices or population shifts. However, for those communities that do rely on a given set of climatic conditions for their livelihoods, projected changes to those conditions may provide advance warning of loss of livelihoods and potential political or social consequences. Descriptions of the associated anthromes are based on descriptions from Ellis et al. 2008. Additional information regarding the percentage of landcover and percentage change of landcover for each anthrome type is located in the Appendix (Table 4 through Table 24).

\subsubsection{Rainfed villages (Table 4 through Table 6)}

Rainfed villages are part of the village group that is defined as dense agricultural settlements. Globally, this is the most extensive of the densely populated biomes. Specifically, rainfed villages are villages dominated by rainfed agriculture.

\section{During the 2030s epoch}

For RCP 4.5, El Salvador and Guatemala have more than 10\% of their total area as a rainfed village for at least one GCM. El Salvador ranges from 12\% to $30 \%$ across all GCMs, and Guatemala ranges from $10 \%$ to $20 \%$. When compared to historic values, El Salvador shows a decrease for each of the climate simulations ranging from a decrease of $45 \%$ to nearly $80 \%$ while Guatemala does not decrease quite as much, only between $5 \%$ to $42 \%$.

Similarly to RCP 4.5, for RCP 6.0, El Salvador and Guatemala have more than $10 \%$ of their land as rainfed villages across all GCMs. El Salvador ranges in percentage of amount from $18 \%$ to $27 \%$ and Guatemala $12 \%$ to $20 \%$. El Salvador shows a percentage decrease from the historical amounts ranging from $52 \%$ to $68 \%$, and Guatemala shows only a $1 \%$ to $20 \%$ decrease.

For RCP 8.5, once again El Salvador and Guatemala have 10\% of their land as rainfed villages for at least one of the GCMs. El Salvador ranges in values from $15 \%$ to $28 \%$ while Guatemala is approximately $15 \%$ for all GCMs. El Salvador shows a decrease from historic in every GCM ranging from a decrease of $50 \%$ to $75 \%$. Guatemala has less of a decrease ranging from $10 \%$ to $30 \%$. 
During the 2050s epoch

For RCP 4.5, El Salvador and Guatemala have more than 10\% of their land as rainfed villages for majority of the GCMs. They have approximately $8 \%$ to $23 \%$ of land as rainfed villages. El Salvador has a $60 \%$ to $85 \%$ decrease of rainfed village area compared to the historic time period. However, Guatemala does not have that steep of a decrease and ranges from a 20\% increase to a $30 \%$ decrease.

Increasing from RCP 4.5, for RCP 6.o El Salvador and Guatemala have more than $10 \%$ of their land as rainfed village for all GCMs at approximately $13 \%$ to $20 \%$ of land area. El Salvador has a decrease from historic of approximately $65 \%$ to $80 \%$ while Guatemala ranges from no decrease from historic values to a $30 \%$ decrease.

For RCP 8.5, Guatemala has at least 10\% of its land as rainfed villages for all GCMs while El Salvador has at least $10 \%$ of land as rainfed villages for approximately half of the GCMs. Belize has $10 \%$ for one GCM. All countries have a very similar range of rainfed village area; El Salvador ranges in area from $5 \%$ to $20 \%$, Guatemala $12 \%$ to $20 \%$, and Belize $0 \%$ to $12 \%$. El Salvador has the largest decreases from historic ranging from $60 \%$ to $90 \%$. Guatemala has smaller decreases ranging from $1 \%$ to $35 \%$. Belize has no rainfed village area during the historic time period but has approximately $12 \%$ for the GCM developed at the Institut Pierre-Simon Laplace (France).

During the 2080s epoch

For RCP 4.5, Guatemala has at least 10\% as rainfed villages for all GCMs; El Salvador has $10 \%$ of its total area as rainfed villages for most of the GCMs. In general, countries range between $5 \%$ to $20 \%$ of total area as rainfed village. El Salvador has a decrease in rainfed villages compared to the historic amounts by $65 \%$ to $92 \%$. However, Guatemala has a change in rainfed villages ranging from a $45 \%$ decrease to $3 \%$ increase.

For RCP 6.0, no single country has more than $10 \%$ of their total area as rainfed villages for all GCMs. However, El Salvador, Guatemala, and Belize have more than $10 \%$ for at least one of the scenarios. Overall, they are very similar is aerial extent across the GCMs ranging from $5 \%$ to $22 \%$. When compared historically, El Salvador shows a decrease from every climate scenario ranging from $70 \%$ to $92 \%$. Guatemala ranges from decreasing by 
$50 \%$ compared to historic to increasing by $20 \%$. Belize had no area as rainfed villages in the historic, and nearly half the GCMs show approximately $10 \%$ aerial coverage during this time period.

For RCP 8.5, Guatemala has a least $10 \%$ of its area as rainfed villages in all of the GCMs. Belize and El Salvador have at least 10\% of their total area as rainfed villages for at least one of the GCMs. Belize ranges in area from $0 \%$ to $25 \%$ while Guatemala has approximately $15 \%$ for all GCMs, and El Salvador ranges from 4\% to 30\%. El Salvador decreases for all GCMs ranging from $45 \%$ to $93 \%$ decrease. Belize had no rainfed villages in the historic period and now ranges from o to $25 \%$. Guatemala decreases approximately $7 \%$ to $30 \%$.

\subsubsection{Residential rainfed croplands (Table 7 through Table 9)}

Residential rainfed croplands are part of the croplands group, which is defined as annual crops mixed with other land uses and land covers. Croplands are the second most extensive anthropogenic biome. Precisely, residential rainfed croplands are rainfed croplands with substantial human populations.

\section{During the 2030s epoch}

For RCP 4.5, Belize has $0 \%$ to $13 \%$ of its land as residential rainfed croplands. Guatemala, Nicaragua, and Honduras have $35 \%$ to $63 \%$ while El Salvador has $70 \%$ to $88 \%$ as residential rainfed croplands. All of the countries show an increase compared to the historic value for at least some of the GCMs. Belize had o\% coverage as residential rainfed croplands for the historic time period and has up to $13 \%$ for certain GCMs for the 2030 s epoch. Honduras, Nicaragua, and El Salvador increase for all GCMs ranging from $10 \%$ to $37 \%$ and $65 \%$ to $110 \%$, respectively. Similarly, Guatemala increases for all GCMs, ranging from $30 \%$ to $110 \%$ increase.

Similarly to RCP 4.5 , for RCP 6.0 Belize has $0 \%$ to $10 \%$ as residential rainfed croplands while Guatemala, Nicaragua, and Honduras have between $25 \%$ to $55 \%$. El Salvador has the highest amount between $73 \%$ to $80 \%$. Every country showed an increase for all the GCMs compared to historic values. Belize had o\% for the historic value and is predicted to have up to $10 \%$ aerial coverage of residential rainfed croplands. Honduras had the smallest percent change increases ranging from $35 \%$ to $40 \%$. 
Guatemala increases $15 \%$ to $95 \%$ while Nicaragua increases $8 \%$ to $25 \%$. The largest percent increase of $75 \%$ to $93 \%$ corresponds with El Salvador.

In general, for RCP 8.5, the countries have a fairly similar amount of residential rainfed croplands compared to RCP 4.5 and RCP 6.0. Guatemala, Nicaragua, and Honduras have a range of $33 \%$ to $53 \%$ as residential rainfed croplands while El Salvador has a range between $68 \%$ to $80 \%$. When compared to historic values, Honduras has a percent difference of less than $50 \%$ (either increase or decrease) from the historic value. Guatemala and El Salvador have a percent increase from the historic value for all GCMs ranging from $23 \%$ to $93 \%$ and $63 \%$ to $90 \%$. Nicaragua ranges between a decrease of $3 \%$ and increase of $30 \%$.

\section{During the 2050s epoch}

Belize has a range of residential rangelands between $0 \%$ to $40 \%$ while Guatemala, Nicaragua, and Honduras have a range of values between 35\% to $63 \%$. El Salvador has the largest ranging between $77 \%$ to $90 \%$. Belize has zero residential rainfed croplands in the historic period and has up to $40 \%$ for the 2050s epoch depending upon the GCM. All of the countries have an increase in residential rainfed croplands for all GCMs. Honduras and Nicaragua have a percent increase between $10 \%$ to $58 \%$, Guatemala increases between $25 \%$ to $120 \%$, and El Salvador has the highest increase at $85 \%$ to $110 \%$.

For RCP 6.o, Belize has the smallest amount of residential rainfed croplands ranging between $2 \%$ to $35 \%$. Guatemala, Honduras, and Nicaragua have approximately the same range of residential rainfed croplands ranging between $33 \%$ to $60 \%$. Once again, El Salvador is the highest at $80 \%$ to $85 \%$. All GCMs for all countries have an increase from the historic value. Belize increased from $0 \%$ for the historic up to $35 \%$. Honduras and Nicaragua increase $10 \%$ to $38 \%$; Guatemala increases approximately $10 \%$ to $120 \%$ from the historic value while El Salvador increases $87 \%$ to $105 \%$.

For RCP 8.5, Belize has the largest range of residential rainfed croplands between $0 \%$ to $50 \%$ while Guatemala, Nicaragua, and Honduras range between $35 \%$ to $67 \%$. Again, El Salvador has the highest amount ranging between $75 \%$ to $90 \%$. Belize has $0 \%$ of residential rainfed croplands in the historic period and increases up to $50 \%$ of total area. Honduras increases $10 \%$ to $32 \%$ while Guatemala increases by $25 \%$ to $125 \%$; Nicaragua has a 
percent difference from historic of an increase between $10 \%$ to $55 \%$. El Salvador has the largest increase between $78 \%$ to $115 \%$.

\section{During the 2080s epoch}

Similarly to the 2050 s epoch for RCP 4.5 , during the 2080 s all countries have at least one GCM with $10 \%$ of its land as residential rainfed croplands. Overall, the percent range of residential rainfed croplands remains fairly consistent compared to the 2050s epoch. Belize ranges between $0 \%$ to $40 \%$ while Guatemala, Nicaragua, and Honduras range between $35 \%$ to $68 \%$ as residential rainfed croplands. Consistently El Salvador has been the highest ranging between $80 \%$ to $95 \%$. Belize has $\mathrm{o} \%$ for the historic period for residential rainfed croplands and is projected to have as much as $40 \%$ of its land as residential rainfed croplands by the 2080s. Honduras and Nicaragua have a percent increase ranging between $8 \%$ to $60 \%$. Guatemala has the largest ranging between $40 \%$ to $140 \%$ increase, and El Salvador has the largest percent increase ranging between $90 \%$ to $125 \%$.

For RCP 6.0, Belize has between $0 \%$ to $30 \%$ as residential rainfed croplands while Guatemala, Nicaragua, and Honduras range between $33 \%$ to $65 \%$ for residential rainfed croplands. El Salvador has the most at $78 \%$ to $90 \%$. Compared to historic values, Belize has o\% for the historic time period and is projected to have up to $30 \%$ as residential rainfed croplands by the 2080s. Honduras and Nicaragua have an increase in residential rainfed croplands of $5 \%$ to $60 \%$. Guatemala ranges increase between $30 \%$ to $135 \%$ while El Salvador has consistently the highest range of percentage increase, between $85 \%$ to $115 \%$.

Belize has the largest range of percentages for RCP 8.5, ranging between $5 \%$ to $83 \%$ while Honduras ranges between $25 \%$ to $50 \%$ and Guatemala and Nicaragua between $30 \%$ to $85 \%$. El Salvador has the largest percentage ranging between $65 \%$ to $90 \%$. When compared to historic values, Belize had o\% for the historic and is projected up to $83 \%$ for residential rainfed croplands in the 2080s. Honduras and Nicaragua have an increase and decrease in percent changes ranging between increase of $40 \%$ and decrease $2 \%$ and increase of $75 \%$ to decrease of $10 \%$, respectively. El Salvador has a percent increase of $57 \%$ to $110 \%$. 


\subsubsection{Populated croplands (Table 10 through Table 12)}

Populated croplands include irrigated and rainfed croplands; it is part of the croplands group that is defined as annual crops mixed with other land uses and land covers. Additionally, it is associated with croplands having minor human populations.

\section{During the 2030s epoch}

For RCP 4.5, Belize and Guatemala range between $5 \%$ to $15 \%$ of total area as populated croplands. Belize increases from $0 \%$ in the historic up to $15 \%$ in the 2030 s epoch. Guatemala has a large range in percent difference compared to the historic value, ranging from $42 \%$ decrease to $375 \%$ increase.

Belize is the only country for RCP 6.0 to have at least one GCM with $10 \%$ of the area as populated cropland; it increased from $0 \%$ in the historic up to $15 \%$ in the 2030 s epoch

Similarly for RCP 8.5, Belize is the only country with at least $10 \%$ of populated cropland for one GCM. During the historic period, it had o\% as populated cropland and increased during the time period up to $18 \%$ for the highest GCM projections.

\section{During the 2050s epoch}

Similarly to the 2030s epoch for RCP 4.5, Belize and Guatemala have at least $10 \%$ of their land as populated croplands for at least one GCM. Belize's populated croplands percent ranges between $3 \%$ to $23 \%$ while Guatemala ranges between $1 \%$ to $10 \%$. Belize had $0 \%$ populated croplands for the historic value and now ranges up to $23 \%$ of land coverage. Guatemala has a large range in percentage change from historic of populated croplands, between a decrease of $37 \%$ to an increase of $400 \%$.

For RCP 6.0 and 8.5, Belize did not have any populated croplands in the historic period and now ranges up to $12 \%$.

\section{During the 2080s epoch}

Unlike RCP 4.5, for the 2030 s and 2050s, during the 2080s, only Belize had at least one GCM with at least 10\% of its land as populated cropland. 
Belize increased from zero during the historic period, with GCMs predicting as much as $10 \%$ of land as populated croplands.

For RCP 6.o, Guatemala and Belize had at least one GCM with 10\% as populated cropland; they had approximately $1 \%$ to $10 \%$ of their land as populated cropland. Belize increased from $0 \%$ during the historic up to $10 \%$. Guatemala ranged from decrease of $27 \%$ to increase of $400 \%$ compared to historic values.

For RCP 8.5, no country had a GCM with at least 10\% of populated cropland.

\subsubsection{Residential rangelands (Table 13 through Table 15)}

Residential rangeland is part of the rangeland group that is defined as having livestock grazing with minimal forests and crops. Specifically, residential rangelands are rangelands that have substantial human populations.

\section{During the 2030s epoch}

For the 2030s, only Nicaragua had at least $10 \%$ of the land as residential rangeland for at least one GCM. For RCP 4.5, Nicaragua ranged between $3 \%$ to $10 \%$ as residential rangeland, which is a percent difference from the historic value between decreasing by $37 \%$ to increasing by $135 \%$.

No countries met the requirement for RCP 6.0 or 8.5 .

During the 2050s epoch

For RCP 4.5, only Nicaragua met the minimum criteria with a range of $3 \%$ to $20 \%$ as residential rangeland. This is a percent difference from the historic values between a decrease of $28 \%$ and increase of $360 \%$.

No country met the minimum criteria for RCP 6.o.

Continuing the trend from $\mathrm{RCP} 4.5$, only Nicaragua met the minimum criteria for RCP 8.5 with a range of $1 \%$ to $13 \%$ of land as residential rangeland. Compared to the historic value, this is a change ranging from a decrease of $65 \%$ to increase of $190 \%$. 
During the 2080s epoch

Similarly to the 2030 s and 2050 s epoch for RCP 4.5 , only Nicaragua had at least $10 \%$ of its land as residential rangeland for at least one GCM with a range of $3 \%$ to $20 \%$. Compared to historic values, this ranges from an increase and decrease with an increase of $330 \%$ to a decrease of $20 \%$.

However, during RCP 6.0 Nicaragua and El Salvador met the minimum requirement for residential rangeland area and ranged from $2 \%$ to $18 \%$ and $1 \%$ to $10 \%$, respectively. Compared to historic values, this is a percent increase of $57 \%$ to $1310 \%$ for El Salvador, and for Nicaragua it ranges from a percent decrease of $53 \%$ to percent increase of $290 \%$.

Continuing with the trend from RCP 6.0, for RCP 8.5 El Salvador has between $0 \%$ to $15 \%$ of its land as residential rangeland, and Nicaragua has between $3 \%$ to $15 \%$. When compared to historic values, this percent difference ranges between an increase of $1,770 \%$ to a decrease of $100 \%$ for El Salvador. The large increase in El Salvador during the 2080s epoch is largely due to having a small amount of residential rangeland in the historic period and therefore having very large percent differences when compared to future projections. Nicaragua ranges from a decrease of $37 \%$ to increase of $210 \%$.

\subsubsection{Residential woodlands (Table 16 through Table 18)}

Residential woodlands are based on the forested group that is described as forests with some agriculture and human populations. In general, residential woodlands refer to forests with substantial human populations.

During the 2030s epoch

For RCP 4.5, Guatemala and Nicaragua have approximately 5\% to $10 \%$ as residential woodlands. Belize has between $10 \%$ to $18 \%$ residential woodlands while Honduras ranges between $25 \%$ to $35 \%$. Some countries experience an increase in residential woodlands while others experience a decrease. Increase in residential woodlands occurs across all GCMs in Belize and Honduras with ranges of $110 \%$ to $250 \%$ and $3 \%$ to $13 \%$, respectively. Nicaragua also has a percent increase of $25 \%$ to $165 \%$. Guatemala experiences an increase and decrease in the GCMs ranging from $5 \%$ increase to $50 \%$ decrease. 
Similarly to RCP 4.5, Guatemala and Nicaragua have the smallest amount of populated woodlands between $5 \%$ to $15 \%$. Belize ranges between $10 \%$ to $25 \%$ while Honduras ranges between $20 \%$ to $25 \%$. Compared to historic values, Guatemala and Honduras increase and decrease ranging from $45 \%$ increase to $48 \%$ decrease and $5 \%$ increase to $10 \%$ decrease while Belize decreases across all GCMs ranging from $5 \%$ to $375 \%$. Nicaragua increases $40 \%$ to $150 \%$.

Continuing with the same pattern, the same countries are once again analyzed for RCP 8.5. All countries are very similar in the percentage of land as residential woodlands. Guatemala and Honduras range between $5 \%$ to $12 \%$ while Belize and Honduras range between $15 \%$ to $35 \%$. When compared to historic values, an increase and decrease occurred in Guatemala ranging from an increase of $12 \%$ to decrease of $40 \%$. Honduras experienced an increase across all GCMs at $5 \%$ to $20 \%$ while Nicaragua has a percent difference increase of $45 \%$ to $140 \%$.

\section{During the 2050s epoch}

In general for RCP 4.5, Belize and Honduras are very similar ranging from $10 \%$ to $35 \%$ of residential woodlands across all GCMs, with Nicaragua slightly less at $5 \%$ to $15 \%$. All GCMs remain fairly close to the historic value for Honduras with increases less than $20 \%$ while Belize has a higher range of increase at $100 \%$ to $625 \%$. Nicaragua has a percent difference increase of $30 \%$ to $280 \%$.

For RCP 6.0, Guatemala and Nicaragua have between $5 \%$ to $18 \%$ of their land as residential woodlands. Belize has the largest range of GCMs land percentages ranging from $8 \%$ to $35 \%$. Approximately $25 \%$ to $35 \%$ of land is residential woodlands for Honduras. Compared to historic values, Guatemala has some GCMs that project an increase in aerial coverage of residential woodlands while some predict a decrease; these changes range from an increase of $67 \%$ to decrease of $50 \%$. Nicaragua has a percent difference increase of $48 \%$ to $175 \%$. Additionally, a percent difference increase is projected in all GCMs for Belize and Honduras ranging from $75 \%$ to $600 \%$ and $4 \%$ to $12 \%$, respectively.

Similarly for RCP 8.5, Guatemala and Nicaragua have between $4 \%$ to $20 \%$ of their land as residential woodlands and $20 \%$ to $30 \%$ for Honduras. Belize has the widest range of residential woodlands between $8 \%$ to $45 \%$. Belize has biggest change compared to the historical value ranging from 
$60 \%$ to $835 \%$ increase. Honduras and Nicaragua also have an increase in residential woodlands for all GCMs ranging from $3 \%$ to $33 \%$ and $80 \%$ to $340 \%$, respectively. Similarly to RCP 6.0, Guatemala has an increase and decrease in aerial coverage of residential woodlands ranging from a percent difference increase by $35 \%$ and decrease of $53 \%$.

During the 2080s epoch

For RCP 4.5 overall, the countries are similar in percentage ranges of residential woodlands with Guatemala and Nicaragua ranging between $5 \%$ to $25 \%$ and Honduras ranging $13 \%$ to $35 \%$. Once again, Belize has the highest amount ranging from $18 \%$ to $55 \%$. Belize has the largest change from historic values ranging between an increase of $260 \%$ to $1040 \%$ across all GCMs. Guatemala increases and decreases compared to historic values ranging between a percent difference decrease of $122 \%$ to an increase of $53 \%$. Honduras also increases across all GCMs ranging from $1 \%$ to $35 \%$; Nicaragua has a percent difference increase of $43 \%$ to $270 \%$.

Guatemala and Nicaragua have a range of $5 \%$ to $20 \%$ of their land as residential woodlands, and Honduras ranges between $18 \%$ to $35 \%$ for RCP 6.o. The highest amount is Belize with $23 \%$ to $53 \%$ projected as residential woodlands. Most of the countries remain fairly similar to their historic amounts with the exception of Belize, which has percent difference of an increase between $370 \%$ to $950 \%$. Honduras and Nicaragua also increase ranging from $10 \%$ to $15 \%$ and $30 \%$ to $225 \%$, respectively. GCMs that show an increase and decrease in residential woodlands were in Guatemala and range from an increase by $75 \%$ to a decrease of $55 \%$.

Overall, the countries are fairly similar in the percent coverage of residential woodlands for RCP 8.5 . Guatemala has $3 \%$ to $15 \%$ while Honduras ranges between $15 \%$ to $30 \%$ across GCMs for residential woodlands; Nicaragua has between $5 \%$ to $25 \%$. The widest range, once again, is Belize between 3\% to 60\%. Unlike the other scenarios, Belize shows an increase and decrease compared to historic values ranging from a percent difference increase of $1130 \%$ to a decrease of $40 \%$. Guatemala and Honduras also have a range including increasing and decreasing of residential woodlands ranging between an increase of $42 \%$ and decrease of $75 \%$, and increase $50 \%$ to decrease $13 \%$, respectively. Nicaragua has a percent difference compared to historic between $50 \%$ to $500 \%$ increase. 


\subsubsection{Populated woodlands (Table 19 through Table 21)}

Populated woodlands are based on the forested group that is described as forests with some agriculture and human populations. In general, populated woodlands refer to forests with minor human populations.

During the 2030s epoch

For RCP 4.5, Guatemala has between $5 \%$ to $15 \%$ of its land as populated woodlands; Honduras and Nicaragua have between $20 \%$ to $40 \%$ while Belize has the most with $53 \%$ to $65 \%$ as populated woodlands. Compared to the historic levels Honduras remained fairly close. However, Guatemala showed a percent difference decrease of $30 \%$ to $65 \%$ of populated woodlands and Belize showed a decrease of $20 \%$ to $35 \%$. Nicaragua ranges from a percent difference increase of $20 \%$ to decrease of $5 \%$

In comparison to RCP 4.5, for RCP 6.0, Honduras remained very similar to its RCP 4.5 projections at approximately $20 \%$ to $30 \%$ of the land as populated woodlands. Guatemala showed a small increase ranging from $13 \%$ to $23 \%$, and Belize had an increase up to $65 \%$ to $77 \%$ of the area as populated woodlands. Nicaragua ranges between $8 \%$ to $45 \%$. Once again, most countries remained fairly close to their historic level, with a percent difference increasing or decreasing by $30 \%$ or less with the exception of Nicaragua having a percent difference decrease between $10 \%$ to $40 \%$.

Guatemala remains the smallest area of populated woodlands at $7 \%$ to $17 \%$ for RCP 8.5. Honduras remains similar to RCP 4.5 and 6.0 projections at $20 \%$ to $28 \%$; Nicaragua ranges between $35 \%$ to $45 \%$ while Belize is still the largest of populated woodlands at $58 \%$ to $65 \%$. Belize and Honduras have a percent difference decrease by less than $30 \%$ across all GCMs. Guatemala and Nicaragua also decrease, but a little higher at $23 \%$ to $45 \%$ and $7 \%$ to $40 \%$, respectively.

\section{During the 2050s epoch}

Similarly for the 2050s compared with the 2030s, Guatemala has $10 \%$ to $15 \%$ of its land as populated woodlands. Honduras and Nicaragua range between $15 \%$ to $38 \%$ of populated woodlands while Belize has the highest percentage of populated woodlands at $30 \%$ to $63 \%$. When compared to historic levels, Belize and Guatemala decrease between 20\% to $35 \%$ and 
$30 \%$ to $65 \%$, respectively. Honduras and Nicaragua remain within $20 \%$ of their historic values.

Overall, the general amount for populated woodlands is similar from RCP 4.5 to RCP 6.0 with Guatemala having $8 \%$ to $18 \%$ as populated woodlands and Nicaragua between $10 \%$ to $40 \%$. Honduras has approximately $25 \%$ across all GCMs, and Belize has the most at $43 \%$ to $60 \%$. Belize, Guatemala, and Honduras had a decrease in populated woodlands compared to the historic levels, ranging from $25 \%$ to $50 \%, 30 \%$ to $53 \%$, and $0 \%$ to $20 \%$, respectively. Nicaragua has a percent difference of and increase and decrease compared to historic values of $30 \%$ and $15 \%$, respectively.

For RCP 8.5 across all GCMs, Guatemala has approximately 10\%, and Honduras and Nicaragua range from $15 \%$ to $35 \%$. Again, Belize has the most ranging from $23 \%$ to $58 \%$. When compared to historic amounts, Belize and Honduras show percent difference decreases in populated woodlands across all GCMs at $30 \%$ to $73 \%$ and $7 \%$ to $30 \%$, respectively. Guatemala has a decrease of $55 \%$ to $63 \%$. Similarly to RCP 6.0, Nicaragua has a percent difference increase and decrease compared to historic values at $11 \%$ and $30 \%$, respectively.

\section{During the 2080s epoch}

For RCP 4.5, Guatemala has the smallest percentage ranging from $5 \%$ to $15 \%$; Honduras and Nicaragua range from $15 \%$ to $35 \%$. Once again, Belize is the largest ranging from $15 \%$ to $63 \%$. All countries have deviated substantially from their historic values. Belize, Guatemala, and Honduras present percent difference of decreases ranging from $25 \%$ to $83 \%, 35 \%$ to $78 \%$, and $1 \%$ to $43 \%$, respectively. Nicaragua ranges from a percent difference increase of $13 \%$ to decrease of $55 \%$.

Similarly to RCP 4.5, for RCP 6.0, Honduras and Nicaragua range from $13 \%$ to $35 \%$. Keeping with the trend, Belize has the highest populated woodlands ranging from $17 \%$ to $63 \%$. All countries exhibit a decrease in populated woodlands area for at least one of the GCMs. Populated woodlands decreased for Belize, Guatemala, and Honduras ranging from $25 \%$ to $80 \%, 50 \%$ to $68 \%$, and $5 \%$ to $55 \%$, respectively. Once again, Nicaragua has an increase and decrease at $8 \%$ and $40 \%$, respectively.

When compared to the 2050s epoch for RCP 8.5, Guatemala no longer has at least one GCM with $10 \%$ of its area as populated woodlands. Honduras 
and Nicaragua range from $15 \%$ to $28 \%$ across the GCMs. Consistently, Belize has the largest area of populated woodlands ranging from $1 \%$ to 48\%. Similarly to RCP 6.0 for the 2080 s epoch, all countries experience a percent difference decrease in populated woodlands compared to historic values for at least one of the GCMs. Honduras and Nicaragua had a smaller decrease in ranges across the GCMs at $23 \%$ to $45 \%$ and $13 \%$ to $50 \%$, respectively, compared to Belize at $40 \%$ to $99 \%$.

\subsubsection{Wild woodlands (Table 22 through Table 24)}

Wild woodlands are part of the wildlands group that is land without human populations or agriculture. Specifically, the wild woodlands are defined as having high tree cover and are composed predominantly with tropical and boreal forests.

\section{During the 2030s epoch}

For the 2030 s epoch, Belize for RCP 6.0 is the only place that has at least $10 \%$ of its land as wild woodlands for the 2030 s epoch. However, only one of the climate scenarios has more than $10 \%$ coverage for Belize. In general, the remaining climate scenarios for Belize are approximately $5 \%$ or less of wild woodlands.

Since most of the historic percentages for all of the countries are less than $10 \%$ of the total area per country, it is not surprising that majority of the countries still have less than $10 \%$ of their land as wild woodlands by the 2030s. When comparing to the historic values for Belize, the percent difference ranges from a decrease of $12 \%$ of wild woodlands to an increase of $650 \%$. Since the historic value is fairly small, $1.53 \%$, any increase results in a large percentage increase due to starting with a small number.

\section{During the 2050s epoch}

Belize for RCP 4.5 is the only instance where at least $10 \%$ of the land is wild woodlands for the 2050 s epoch. For this scenario, only one of the GCMs projects Belize at having more than 10\%; the remaining GCMs predict $2 \%$ or less as wild woodlands. The GCM that shows $11 \%$ as wild woodland is the same GCMs in the 2030s epoch for RCP 6.0 that showed Belize as having more than $10 \%$ of the land as wild woodlands then. 
In comparison to the historic values, the percentage difference ranges from a decrease of $99 \%$ to an increase of $630 \%$. Once again, this is largely due to the historic value being small and any changes have a large impact.

During the 2080s epoch

No country has more than $10 \%$ of its land as wild woodlands.

\subsection{Comparison of wet versus dry GCMs}

As shown in Figure 4, different GCMs have tendencies to project either dry, wet, or a mixture of dry and wet conditions for future climates. The comparison of CSIRO-Mk3.6.o (the driest simulation) and GFDL CM3 (the wettest simulation) likely shows the two extremes for future climates for anthromes and biomes. It is difficult to quantify which BCI best correlates with the shift from the baseline. However, the spread of precipitation can help demonstrate the range of precipitation possibilities in the future.

When comparing the dry simulation as shown in Figure 5 and the wet simulation shown in Figure 6 to the anthromes map shown in Figure 3, there are several key differences. Historically, Guatemala is very diverse; however, for the wet and dry simulations, it is dominated by residential rainfed croplands. The dry simulation has more rainfed villages in the northern part but overall remains similar to the wet simulation. These are very different from the historic map, which has a mix of populated croplands, remote woodlands, rainfed villages, and several other anthromes throughout.

Belize completely changed from historic anthromes when looking at future wet and dry simulations. Historically, Belize is dominated by populated woodlands with some remote woodlands. However, the future wet and dry simulations project Belize to be dominated by residential rainfed croplands. The wet simulation shows some rainfed villages, and the dry simulation shows some residential woodlands and populated woodlands in addition to the residential rainfed croplands.

Historically for Honduras, there is a mixture of numerous anthromes but predominately residential rainfed croplands, populated woodlands, and residential woodlands. The wet simulation still shows the same dominant three from the historic time period; however, the location spatially is 
slightly different with a shift of residential woodlands away from the coast and more inland. The dry simulation also has the three anthromes from the historic period in addition to remote woodlands.

El Salvador has approximately $50 \%$ of its land as rainfed village and $50 \%$ as residential rainfed croplands for the historic time period. For the wet simulation, it is dominated by residential rainfed croplands with equal amounts of some residential rangeland and rainfed villages. The dry simulation is also dominated by populate croplands, with even lesser amounts of residential rangeland and rainfed villages.

Historically, Nicaragua is very diverse with the western part dominated by residential rainfed croplands and the eastern part dominated by populated woodlands with a variety of other anthromes throughout. Looking at the future wet simulation, similarly to the historic time period, the western portion is dominated by residential rainfed cropland. However, the residential rainfed cropland has expanded into the eastern portion, where the eastern portion also has populated woodlands, residential rangelands, and various other anthromes. The dry simulation also has residential rainfed croplands for the western half of Nicaragua. The eastern half is approximately half populated woodlands and half residential woodlands. 
Figure 5. Anthrome projections for the 2080 s epoch for RCP 8.5 using the CSIRO-Mk3.6.0 GCM representing the driest simulation.

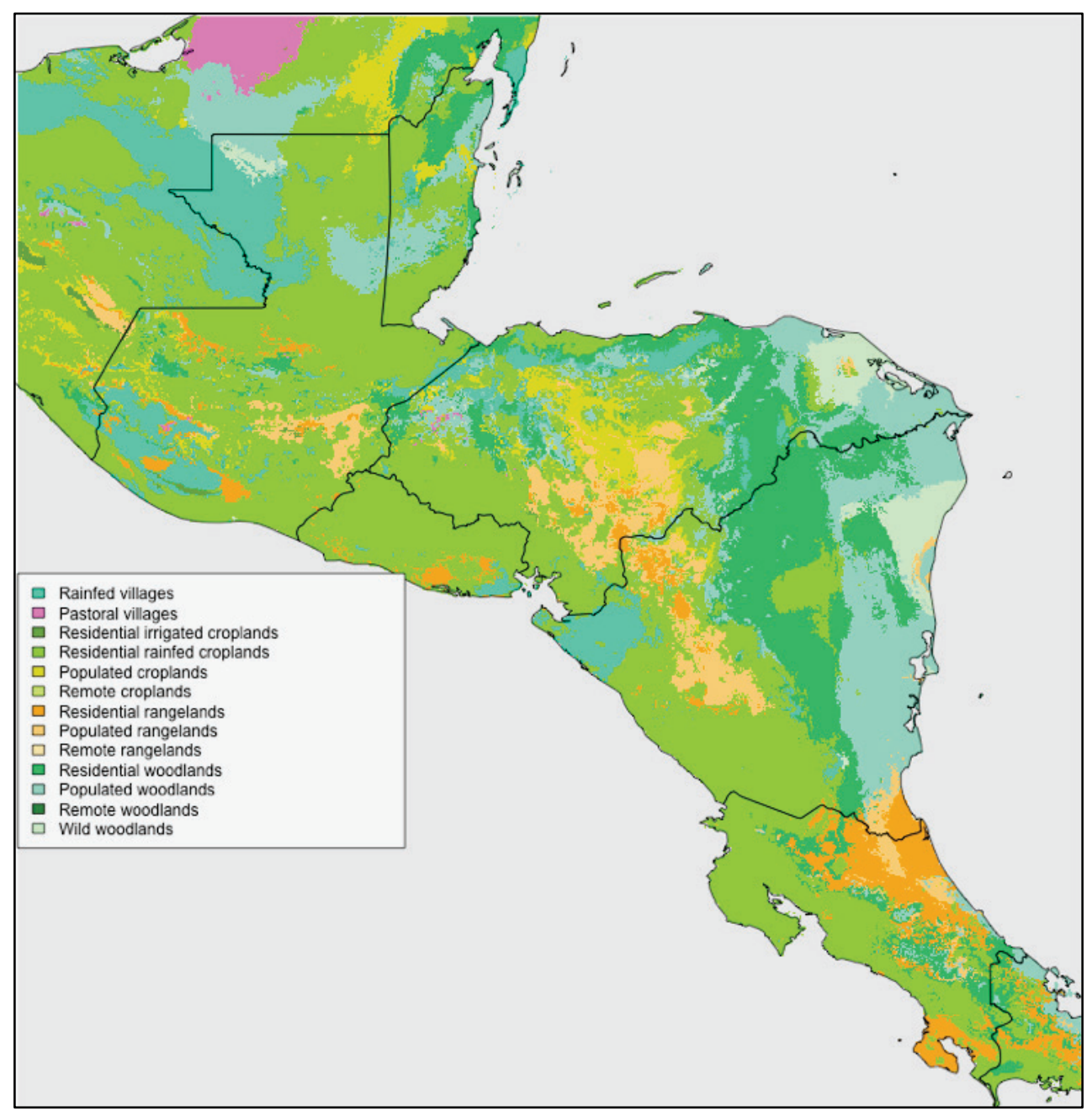


Figure 6. Anthrome projections for the 2080 s epoch for RCP 8.5 using GFDL CM3 GCM representing the wettest simulation.

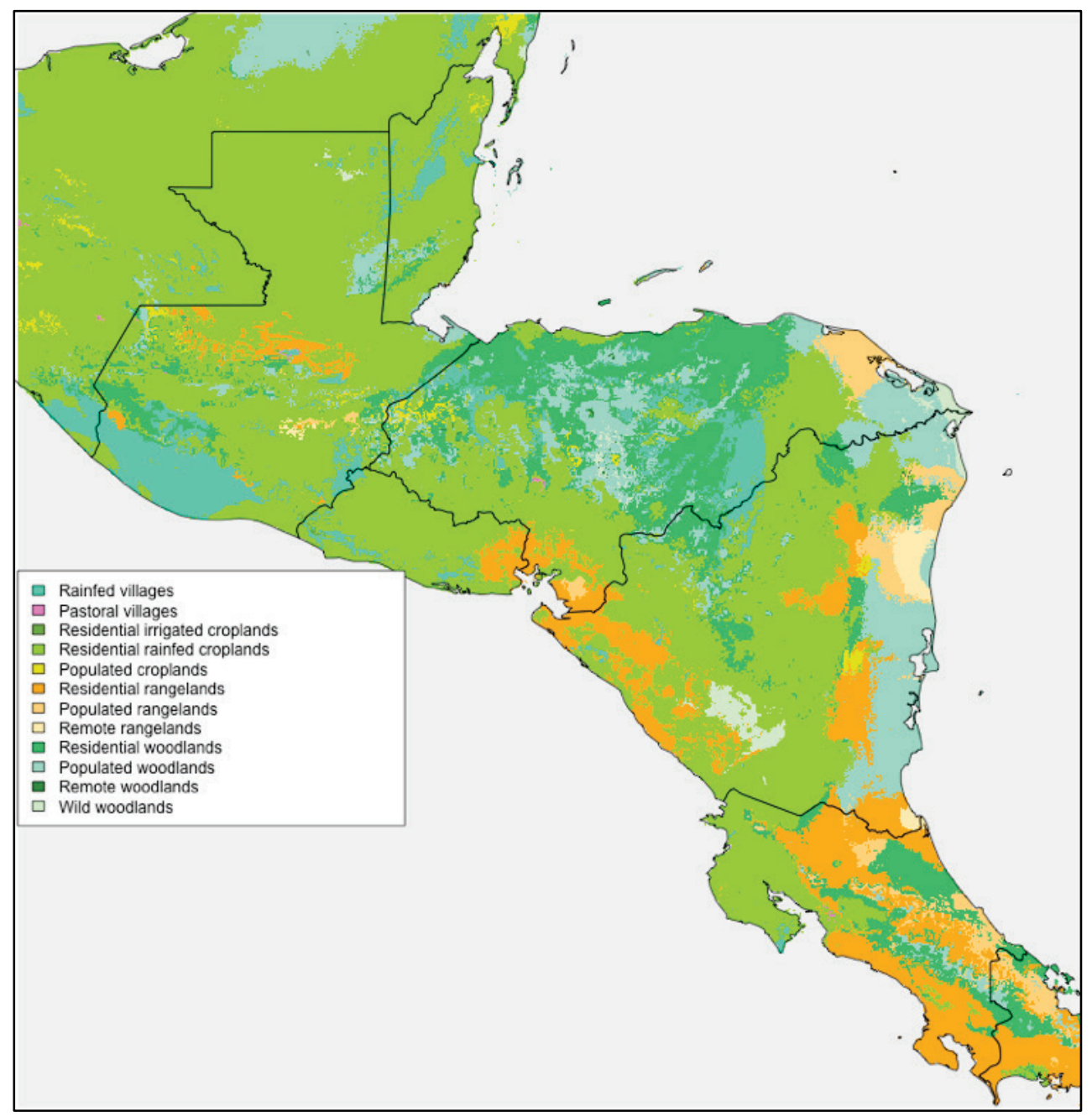

Similarly to the anthromes, the biomes show a change when comparing the historic time period as shown in Figure 2 to the dry simulation in Figure 7 and the wet simulation in Figure 8. Historically, Guatemala is dominated by Petén-Veracruz Moist Forests, Central American Pine Oak Forests, and various other biomes. When compared to the future dry and wet simulations, spatially the biomes remain fairly consistent except for Pantanos De Centla biome replacing much of the Petén-Veracruz Moist Forest and nearly all of the Central American Atlantic Moist Forest.

Belize is historically dominated by Petén-Veracruz Moist Forests. The future dry and wet simulations show a significant decrease in Petén-Veracruz Moist Forests and instead are dominated by Pantanos De Centla, Mesoamerican Gulf-Caribbean Mangroves, and a few various other biomes. 
Figure 7. Biome projections for the 2080s epoch for RCP 8.5 using CSIRO-Mk3.6.0 GCM representing the driest simulation.

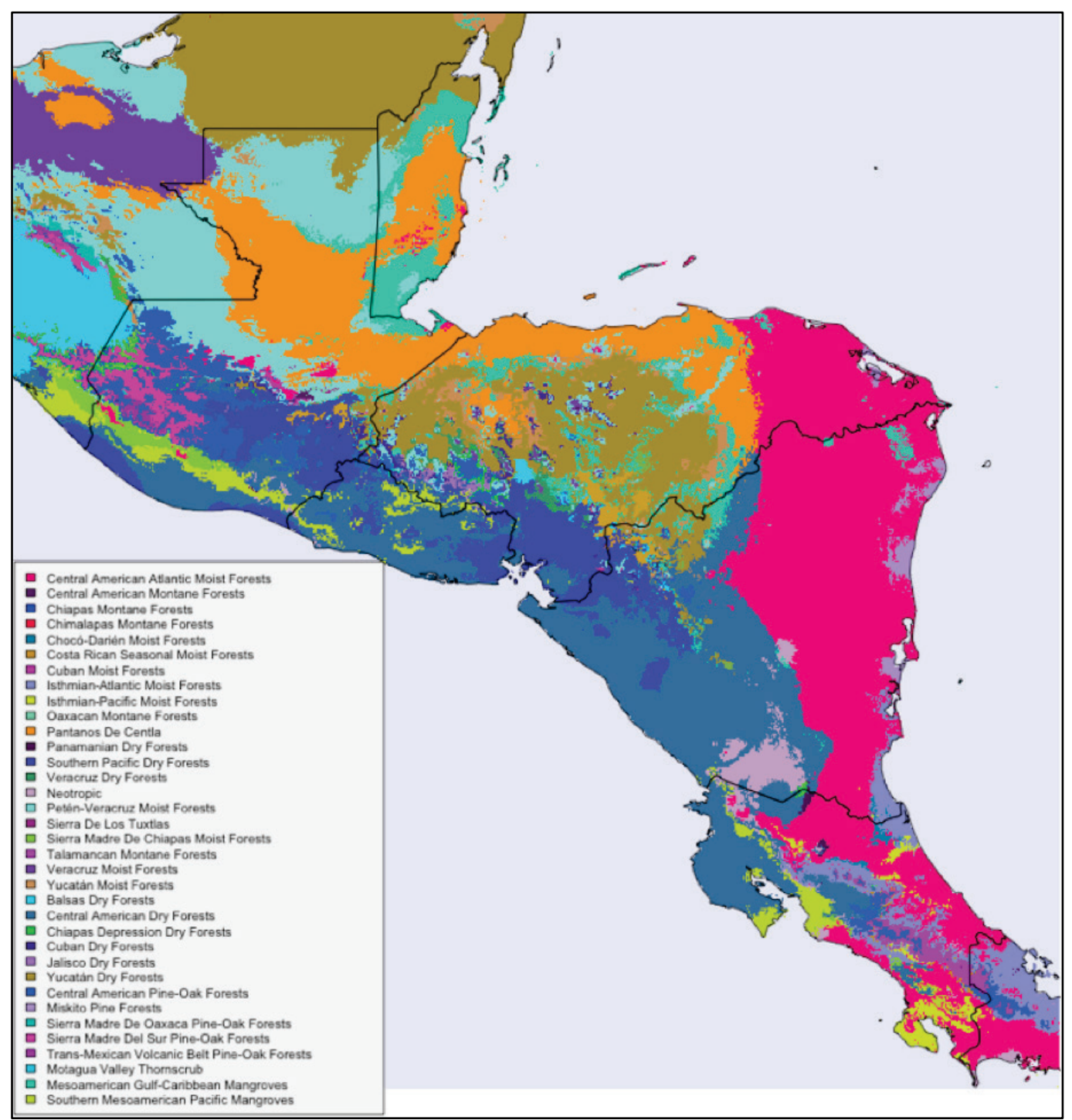

For Honduras historically, it is dominated by Central American Pine-Oak Forest, Central American Atlantic Moist Forests, and various other biomes. However, when the historic biomes are compared to the future biomes for the dry and the wet simulation, there is a substantial change. The wet and dry future simulations have substantial amounts of biomes of Central American Atlantic Moist Forest and Pantanos De Centla. The dry simulation also has Yucatán Dry Forests, Mesoamerican Gulf-Caribbean Mangroves, and Southern Pacific Dry Forests while the wet simulation has PeténVeracruz Moist Forests and Southern Mesoamerican Pacific Mangroves.

Historically, El Salvador is composed of two main biomes: Central American Pine-Oak Forests and Central American Dry Forests. The future 
dry simulation also has Central American Dry Forests, but an increase in amount. Additionally, it has Southern Mesoamerican Pacific Mangroves and Southern Pacific Dry Forests.

Figure 8. Biome projections for the 2080s epoch for RCP 8.5 using GFDL CM3 GCM representing the wettest simulation.

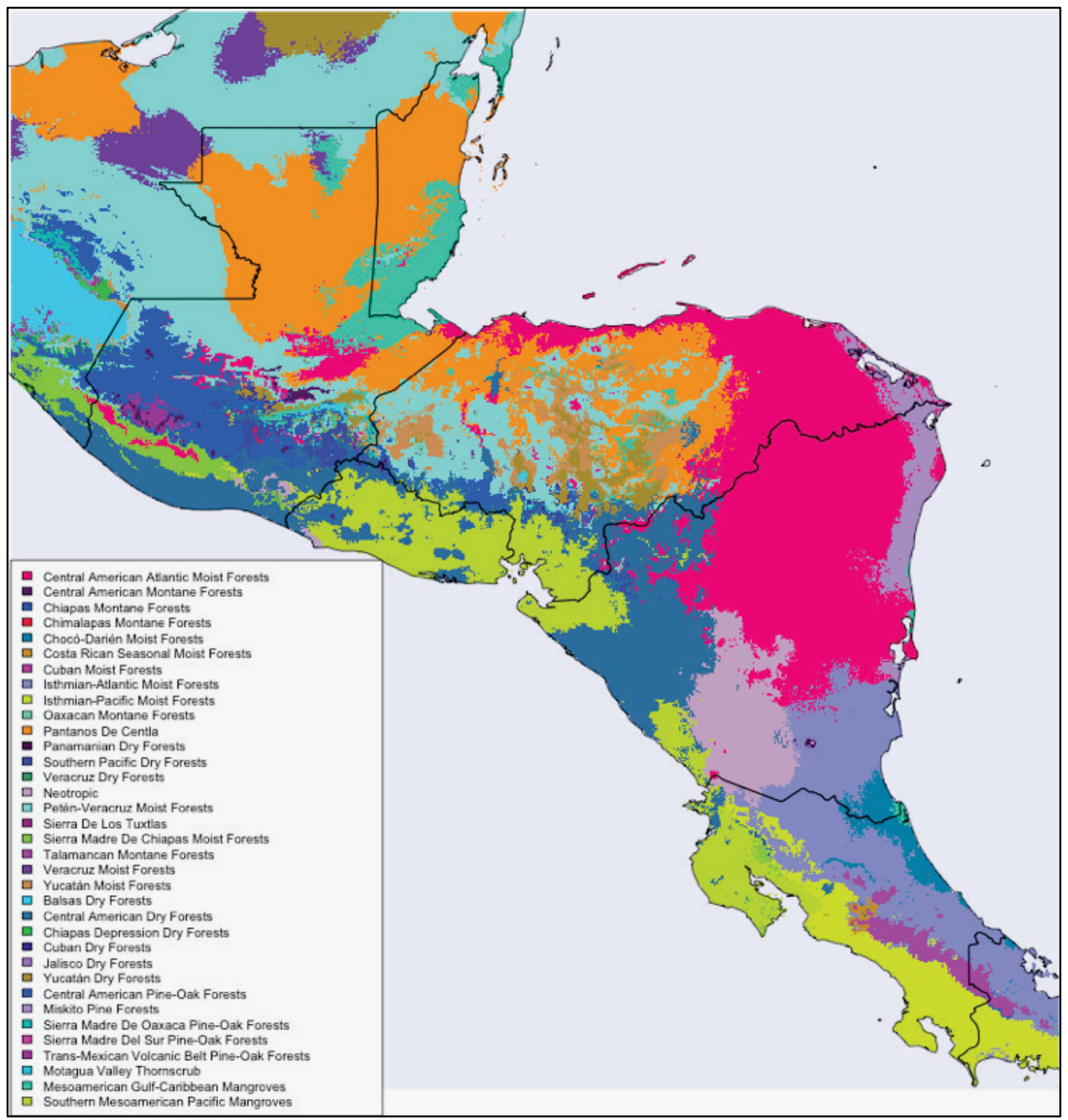

However, the wet simulation has El Salvador with a small amount of Central American Dry Forest but is dominated by Southern Mesoamerican Pacific Mangroves.

Nicaragua is composed of five main biomes for the historic time period including Central American Atlantic Moist Forests, Isthmian-Atlantic Moist Forests, Central American Pine-Oak Forests, Neotropic, and Central 
American Dry Forests. These trends remain largely the same for the wet simulation except with the removal of Central American Pine-Oak Forests and instead Southern Mesoamerican Pacific Mangroves. The dry simulation is dominated with Central American Dry Forests and Central American Atlantic Moist Forests with a variety of other biomes. 


\section{Discussion and Conclusions}

The focus of this study is to examine which locations are likely to change suitability for plant and crop growth as climates in the future are likely to be different than the current climatic conditions. As the climate continues to change, this affects the many biomes and anthromes. Changes in biomes and anthromes signify many aspects. First, changes of biomes and anthromes are likely to impact the availability of food due to changes in cropland suitability, including land availability and appropriate climatic conditions. Additionally, ecological aspects, such as trees, cannot migrate to new areas whereas people and animals can. However, with changing climatic conditions, the trees and plants could potentially cease growing in one area and start growing in another if the plant is introduced there. Some places may not have such a substantial change, and rather than completely migrating or ceasing to exist there, plants and animals may adapt by changing the growing season or adapting to other sources for food. Regardless, changes in biomes and anthromes will cause all aspects of the ecosystem to adapt to survive.

For the Central American region, rainfed villages, residential rainfed croplands, residential woodlands, and populated woodlands are the most prevalent anthromes. Historically, Belize was dominated by populated woodlands. However, in the future, there may be an increase in the amount of residential rainfed croplands and residential woodlands. Guatemala has not been dominated by one particular anthrome historically, and looking into the future, this will continue with a fairly even distribution of area amongst the top four anthromes. Similarly to Guatemala, Honduras is split fairly evenly historically and in the future amongst residential rainfed croplands, residential woodlands, and populated woodlands. Historically, El Salvador is split evenly between rainfed villages and residential rainfed croplands. However, in the future, El Salvador is dominated by residential rainfed croplands and has a substantial decrease in rainfed villages. Nicaragua is historically roughly one-third residential rainfed croplands, one-third populated woodlands, and one-third miscellaneous other anthromes, with this pattern continuing into the future.

Central America is fairly diverse with biomes and is dominated by seven main types: Central American Atlantic Moist Forests, Isthmian-Atlantic Moist Forests, Pantanos De Centla, Petén-Veracruz Moist Forest, Central 
American Dry Forests, Central American Pine-Oak Forests, and Mesoamerican Gulf-Caribbean Mangroves. Belize has been historically dominated by Petén-Veracruz Moist Forest and some Mesoamerican GulfCaribbean Mangroves. Future projections indicate that those two biomes will remain present in addition to Pantanos De Centla. Guatemala was historically dominated by Central American Dry Forests, Petén-Veracruz Moist Forests, and Central American Pine-Oak Forests with future projections showing a decrease in the latter two. Additionally, future projections also show Pantanos De Centla and Central American Atlantic Moist Forests. Historically, Honduras is dominated by Central American Atlantic Moist Forests, Central American Dry Forests, and Central American Pine-Oak Forests. Future projections indicate that all of those biomes will remain present as well as Petén-Veracruz Moist Forest. Nicaragua remains fairly consistent with biomes present historically as well as those projected to be in there under different climate conditions; those biomes are Central American Atlantic Moist Forests, IsthmianAtlantic Moist Forests, and Central American Dry Forests. El Salvador is dominated by Central American Pine-Oak Forests with some Central American Dry Forests, historically. Future projections indicate that these two biomes will continue to be the most common but will switch roles with Central American Dry Forests dominating and having a lesser amount of Central American Pine-Oak Forests. Since biomes are likely not to adapt quickly, especially the forested systems that are the predominant landscape type here, it is likely that there will be changes in biome types, with new biomes developing. This may include exotic species that have a higher capacity to adapt to changing conditions.

While there will be changes in the future for biomes and anthromes, it is difficult to quantify the changes as a "good" or "bad" change. Rather, it is important to note that there is a likelihood of a change that is partially caused by humans and will impact them. However, this study only considers how land suitability changes as a result due to shifts in future climate. While this study does not consider the fact that anthropogenic changes are likely to render areas untenable, this is important to consider when examining the results holistically. Additionally, deforestation and overexploitation of soil resources can have devastating impacts on that land and make it unusable by humans. As anthromes shift, more biomes will also be destroyed, which will leave people even more vulnerable to climatic change. 
These changes show numerous different aspects. From an urban planning perspective, the anthrome maps show which areas are likely to shift away from agricultural areas, likely forcing people to migrate from rural areas to urban areas to find jobs and food. From the perspective of a military planner, the shifts could cause migration that could displace a large group of people who may be susceptible to joining rebel groups or other insurgencies. Politically, the movement of people across national borders could cause political struggles in areas that may already be politically unstable. Additionally, with large groups of people moving, this will cause impacts on infrastructure ranging between roads to travel on or available housing. This could help transportation engineers and developers know where roads or housing may need to be improved or built. Other aspects, such as land degradation and catastrophic events such as a meteoroid impact or war will also impact biomes and anthromes and where people live. However, events such as those are very difficult to predict in timing and amount of destruction.

While it is difficult to predict exactly how people will adapt, people need food and water to survive and will adapt either by migrating or altering their lifestyle to accommodate their new situation. Future research includes applying this methodology to other locations such as the Philippines and South America. This will help determine which areas are at risk and how populations may migrate. 


\section{References}

Bailey, R. G. 1983. "Delineation of Ecosystem Regions.” Environmental Management $7(4): 365-373$.

Bailey, R. G. 1995. Description of the Ecoregions of the United States. 2nd Edition. Misc. Pub. No. 1391. Map scale 1:7,500,000. Washington, DC: USDA Forest Service.

Boivin, N. L., M. A. Zeder, D. Q. Fuller, A. Crowther, G. Larson, J. M. Erlandson, and M. D. Petraglia. 2016. "Ecological Consequences of Human Niche Construction: Examining Long-Term Anthropogenic Shaping of Global Species Distributions." Proceedings of the National Academy of Sciences 113(23): 6388-6396. https://doi.org/10.1073/pnas.1525200113

Brown, D. E., F. Reichenbacher, and S.E. Franson. 1998. A Classification of North American Biotic Communities. Salt Lake City, UT: University of Utah Press.

doParallel: https://cran.r-project.org/web/packages/doParallel/doParallel.pdf

Ellis, E. C., and N. Ramankutty. 2008. "Putting People in the Map: Anthropogenic Biomes of the World." Frontiers in Ecology and the Environment 6(8): 439-447. https://doi.org/10.1890/070062

Global Witness. 2017. Defenders of the Earth. London, UK. https://www.globalwitness.org/en/campaigns/environmental-activists/defenders-earth/

Hijmans, R. J., S. E. Cameron, J. L. Parra, P. G. Jones, and A. Jarvis. 2005. "Very High Resolution Interpolated Climate Surfaces for Global Land Areas.” International Journal of Climatology 25(15): 1965-1978.

Intergovernmental Panel on Climate Change (IPCC). 2014. Climate Change 2014: Synthesis Report. Contribution of Working Groups I, II, and III to the Fifth Assessment Report of the Intergovernmental Panel on Climate Change (Core Writing Team, edited by R. K. Pachauri and L. A. Meyer). IPCC, Geneva Switzerland.

Liaw, A., and M. Wiener. 2002. "Classification and Regression by randomForest." $R$ News 2(3): 18-22.

Meinshausen, M., S. J. Smith, K. Calvin, J. S. Daniel, M. L. T. Kainuma, J-F. Lamarque, K. Matsumoto, S. A. Montzka, S. C. B. Raper, K. Riahi, A. Thomson, G. J. M. Velders, D.P. P. van Vuuren. 2011. "The RCP greenhouse gas concentrations and their extensions from 1765 to 2300." Climatic Change 109(1-2): 213-241.

O’Donnell, M. S., and D. A. Ignizio. 2012. Bioclimatic Predictors for Supporting Ecological Applications in the Conterminous United States. U.S Geological Survey Data Series 691. Reston, VA: U.S Geological Survey.

Olson, D. M., and E. Dinerstein. 2002. "The Global 200: Priority Ecoregions for Global Conservation." Annals of the Missouri Botanical Garden 89: 125-126. 
Omernik, J. M. 1987. "Ecoregions of the Conterminous United States.” Annals of the Association of American Geographers 77(1): 118-125.

Ramirez-Villegas, J., and A. Jarvis. 2010. Downscaling Global Circulation Model Outputs: The Delta Method Decision and Policy Analysis Working Paper No. 1. International Center for Tropical Agriculture. http://ccafsclimate.org/downloads/docs/Downscaling-WP-01.pdf.

Sutton, S. Y. 1988. "Nicaragua." Floristic Inventory of Tropical Countries. Edited by D.G. Campbell and H.D. Hammond, 301-303. Bronx, NY: New York Botanical Garden.

The Nature Conservancy. 2003. Terrestrial Ecozones of Canada. Based on E. B. Wiken. (compiler) 1986. Ecological Land Classification Series No. 19. Environment Canada, Hull, Quebec.

Vitousek, P. M., H. A. Mooney, J. Lubchenco, and J. M. Melillo. 2008. “Human Domination of Earth's Ecosystems." Urban Ecology: An International Perspective on the Interaction Between Humans and Nature. Boston, MA: Springer. https://doi.org/10.1007/978-0-387-73412-5_1

Wiken, E. B. 1986. Terrestrial EcoZones of Canada. Ecological Land Classification Series No. 19. Lands Directorate, Environment Canada.

World Wildlife Federation (WWF). 2017. Ecoregions. https://www.worldwildlife.org/biomes/ 


\section{Appendix: Anthromes and Biomes Percentages}

\section{Anthromes}

Table 4. Rainfed Villages for the 2030s epoch.

\begin{tabular}{|c|c|c|c|c|c|c|c|}
\hline \multirow{2}{*}{} & \multicolumn{4}{|c|}{ Percentage of total land } & \multicolumn{3}{c|}{ Percent decrease from historic } \\
& \multicolumn{4}{|c|}{ value } \\
\cline { 2 - 8 } & Historic & RCP 4.5 & RCP 6.0 & RCP 8.5 & RCP 4.5 & RCP 6.0 & RCP 8.5 \\
\hline Belize & 0 & - & - & - & - & - & - \\
\hline Guatemala & 18.9 & $10-20$ & $12-20$ & $\sim 15$ & $5-42$ & $1-20$ & $10-30$ \\
\hline Honduras & 2.75 & - & - & - & - & - & - \\
\hline El Salvador & 55.14 & $12-30$ & $18-27$ & $15-28$ & $45-80$ & $52-68$ & $50-75$ \\
\hline Nicaragua & 2.15 & - & - & - & - & - & - \\
\hline
\end{tabular}

Table 5. Rainfed Villages for the 2050s epoch.

\begin{tabular}{|c|c|c|c|c|c|c|c|}
\hline & \multicolumn{4}{|c|}{ Percentage of total land } & \multicolumn{3}{c|}{ Percent decrease from historic } \\
& \multicolumn{4}{|c|}{} & \multicolumn{4}{|c|}{ value } \\
\cline { 2 - 8 } & Historic & RCP 4.5 & RCP 6.0 & RCP 8.5 & RCP 4.5 & RCP 6.0 & RCP 8.5 \\
\hline Belize & 0 & - & - & $0-12$ & - & - & $\begin{array}{c}\text { Increase } \\
\text { from 0 }\end{array}$ \\
\hline Guatemala & 18.9 & $10-23$ & $13-20$ & $12-20$ & -20 to 30 & $0-30$ & $1-35$ \\
\hline Honduras & 2.75 & - & - & - & - & - & - \\
\hline El Salvador & 55.14 & $8-20$ & $12-20$ & $5-20$ & $60-85$ & $65-80$ & $60-90$ \\
\hline Nicaragua & - & - & - & - & - & - & - \\
\hline
\end{tabular}

Table 6. Rainfed Villages for the 2080s epoch.

\begin{tabular}{|c|c|c|c|c|c|c|c|}
\hline & \multicolumn{4}{|c|}{ Percentage of total land } & \multicolumn{3}{|c|}{$\begin{array}{l}\text { Percent decrease from historic } \\
\text { value }\end{array}$} \\
\hline & Historic & RCP 4.5 & RCP 6.0 & RCP 8.5 & RCP 4.5 & RCP 6.0 & RCP 8.5 \\
\hline Belize & 0 & - & $9-15$ & $0-25$ & - & $\begin{array}{l}\text { Increase } \\
\text { from } 0\end{array}$ & $\begin{array}{l}\text { Increase } \\
\text { from } 0\end{array}$ \\
\hline Guatemala & 18.9 & $10-20$ & $8-22$ & $\sim 15$ & $\begin{array}{l}-150 \text { to }- \\
400\end{array}$ & -20 to 50 & $7-30$ \\
\hline Honduras & 2.75 & - & - & - & - & - & - \\
\hline El Salvador & 55.14 & $5-20$ & $5-17$ & $4-30$ & $65-92$ & $70-92$ & $45-93$ \\
\hline Nicaragua & - & - & - & - & - & - & - \\
\hline
\end{tabular}


Table 7. Residential Rainfed Croplands 2030s.

\begin{tabular}{|c|c|c|c|c|c|c|c|}
\hline & \multicolumn{4}{|c|}{ Percentage of total land } & \multicolumn{3}{|c|}{$\begin{array}{l}\text { Percent decrease from historic } \\
\text { value }\end{array}$} \\
\hline & Historic & RCP 4.5 & RCP 6.0 & RCP 8.5 & RCP 4.5 & RCP 6.0 & RCP 8.5 \\
\hline Belize & 0 & $0-13$ & $0-10$ & - & $\begin{array}{l}\text { Increase } \\
\text { from } 0\end{array}$ & $\begin{array}{l}\text { Increase } \\
\text { from } 0\end{array}$ & $\begin{array}{l}\text { Increase } \\
\text { from } 0\end{array}$ \\
\hline Guatemala & 27.81 & $35-57$ & $33-55$ & $35-53$ & $\begin{array}{l}-30 \text { to }- \\
110\end{array}$ & -15 to -95 & -23 to -93 \\
\hline Honduras & 31.9 & $35-45$ & $35-40$ & $33-43$ & -10 to -37 & -35 to -40 & -4 to -35 \\
\hline EI Salvador & 41.99 & $70-88$ & $73-80$ & $68-80$ & $\begin{array}{l}-65 \text { to }- \\
110\end{array}$ & -75 to -93 & -63 to -90 \\
\hline Nicaragua & 34.28 & $35-45$ & $\sim 40$ & $33-45$ & -7 to -35 & -8 to -25 & -30 to 3 \\
\hline
\end{tabular}

Table 8. Residential Rainfed Croplands 2050s.

\begin{tabular}{|c|c|c|c|c|c|c|c|}
\hline & \multicolumn{4}{|c|}{ Percentage of total land } & \multicolumn{3}{c|}{ Percent decrease from historic } \\
value \\
\cline { 2 - 8 } & Historic & RCP 4.5 & RCP 6.0 & RCP 8.5 & RCP 4.5 & RCP 6.0 & RCP 8.5 \\
\hline Belize & 0 & $0-40$ & $2-35$ & $0-50$ & $\begin{array}{c}\text { Increase } \\
\text { from 0 }\end{array}$ & $\begin{array}{c}\text { Increase } \\
\text { from 0 }\end{array}$ & $\begin{array}{c}\text { Increase } \\
\text { from 0 }\end{array}$ \\
\hline Guatemala & 27.81 & $38-60$ & $35-60$ & $38-63$ & $\begin{array}{c}-35 \text { to }- \\
120\end{array}$ & $\begin{array}{c}-27 \text { to }- \\
120\end{array}$ & $\begin{array}{c}-35 \text { to - } \\
125\end{array}$ \\
\hline Honduras & 31.9 & $35-50$ & $35-43$ & $35-42$ & -10 to -58 & -10 to -35 & -10 to -32 \\
\hline El Salvador & 41.99 & $77-90$ & $80-85$ & $75-90$ & $\begin{array}{c}-85 \text { to }- \\
110\end{array}$ & $\begin{array}{c}-87 \text { to }- \\
105\end{array}$ & $\begin{array}{c}-78 \text { to }- \\
115\end{array}$ \\
\hline Nicaragua & 34.28 & $38-50$ & $40-47$ & $38-53$ & -10 to -50 & -15 to -38 & -10 to -55 \\
\hline
\end{tabular}

Table 9. Residential Rainfed Croplands 2080s.

\begin{tabular}{|c|c|c|c|c|c|c|c|}
\hline & \multicolumn{4}{|c|}{ Percentage of total land } & \multicolumn{3}{c|}{ Percent decrease from historic } \\
& Historic & RCP 4.5 & RCP 6.0 & RCP 8.5 & RCP 4.5 & RCP 6.0 & RCP 8.5 \\
\hline Belize & 0 & $0-40$ & $0-30$ & $5-83$ & $\begin{array}{c}\text { Increase } \\
\text { from 0 }\end{array}$ & $\begin{array}{c}\text { Increase } \\
\text { from 0 }\end{array}$ & $\begin{array}{c}\text { Increase } \\
\text { from 0 }\end{array}$ \\
\hline Guatemala & 27.81 & $40-68$ & $40-65$ & $45-77$ & $\begin{array}{c}-40 \text { to }- \\
140\end{array}$ & $\begin{array}{c}-43 \text { to - } \\
135\end{array}$ & $\begin{array}{c}-60 \text { to - } \\
180\end{array}$ \\
\hline Honduras & 31.9 & $35-50$ & $33-50$ & $30-45$ & -8 to -55 & -5 to -60 & -40 to 2 \\
\hline El Salvador & 41.99 & $80-95$ & $78-90$ & $65-90$ & $\begin{array}{c}-90 \text { to }- \\
125\end{array}$ & $\begin{array}{c}-85 \text { to }- \\
115\end{array}$ & $\begin{array}{c}-57 \text { to - } \\
110\end{array}$ \\
\hline Nicaragua & 34.28 & $40-55$ & $40-55$ & $30-60$ & -13 to -60 & -20 to -65 & $\begin{array}{c}-75 \text { to } \\
10\end{array}$ \\
\hline
\end{tabular}


Table 10. Populated Croplands 2030s epoch.

\begin{tabular}{|c|c|c|c|c|c|c|c|}
\hline & \multicolumn{4}{|c|}{ Percentage of total land } & \multicolumn{3}{c|}{ Percent decrease from historic } \\
\cline { 2 - 9 } & Historic & RCP 4.5 & RCP 6.0 & RCP 8.5 & RCP 4.5 & RCP 6.0 & RCP 8.5 \\
\hline Belize & 0 & $5-15$ & $1-15$ & $2-18$ & $\begin{array}{c}\text { Increase } \\
\text { from 0 }\end{array}$ & $\begin{array}{c}\text { Increase } \\
\text { from 0 }\end{array}$ & $\begin{array}{c}\text { Increase } \\
\text { from 0 }\end{array}$ \\
\hline Guatemala & 2.14 & $1-10$ & - & - & $\begin{array}{c}-375 \text { to } \\
42\end{array}$ & - & - \\
\hline Honduras & 1.07 & - & - & - & - & - & - \\
\hline El Salvador & 0 & - & - & - & - & - & - \\
\hline Nicaragua & 6.36 & - & - & - & - & - & - \\
\hline
\end{tabular}

Table 11. Populated Croplands 2050s epoch.

\begin{tabular}{|c|c|c|c|c|c|c|c|}
\hline & \multicolumn{4}{|c|}{ Percentage of total land } & \multicolumn{3}{c|}{ Percent decrease from historic } \\
& \multicolumn{1}{|c|}{ Historic } & RCP 4.5 & RCP 6.0 & RCP 8.5 & RCP 4.5 & RCP 6.0 & RCP 8.5 \\
\hline \multirow{2}{*}{ Belize } & 0 & $2-23$ & $1-12$ & $1-12$ & $\begin{array}{c}\text { Increase } \\
\text { from 0 }\end{array}$ & $\begin{array}{c}\text { Increase } \\
\text { from 0 }\end{array}$ & $\begin{array}{c}\text { Increase } \\
\text { from 0 }\end{array}$ \\
\hline Guatemala & 2.14 & $1-10$ & - & - & $\begin{array}{c}-400 \text { to } \\
37\end{array}$ & - & - \\
\hline Honduras & 1.07 & - & - & - & - & - & - \\
\hline El Salvador & 0 & - & - & - & - & - & - \\
\hline Nicaragua & 6.36 & - & - & - & - & - & - \\
\hline
\end{tabular}

Table 12. Populated Croplands 2080s epoch.

\begin{tabular}{|c|c|c|c|c|c|c|c|}
\hline & \multicolumn{4}{|c|}{ Percentage of total land } & \multicolumn{3}{c|}{ Percent decrease from historic } \\
& Historic & RCP 4.5 & RCP 6.0 & RCP 8.5 & RCP 4.5 & RCP 6.0 & RCP 8.5 \\
\hline \multirow{2}{*}{ Belize } & 0 & $5-10$ & $1-10$ & - & $\begin{array}{c}\text { Increase } \\
\text { from 0 }\end{array}$ & $\begin{array}{c}\text { Increase } \\
\text { from 0 }\end{array}$ & $\begin{array}{c}\text { Increase } \\
\text { from 0 }\end{array}$ \\
\hline Guatemala & 2.14 & - & $2-10$ & - & - & $\begin{array}{c}-400 \\
27\end{array}$ & - \\
\hline Honduras & 1.07 & - & - & - & - & - & - \\
\hline El Salvador & 0 & - & - & - & - & - & - \\
\hline Nicaragua & 6.36 & - & - & - & - & - & - \\
\hline
\end{tabular}


Table 13. Residential Rangelands 2030s epoch.

\begin{tabular}{|c|c|c|c|c|c|c|c|}
\hline & \multicolumn{4}{|c|}{ Percentage of total land } & \multicolumn{3}{|c|}{$\begin{array}{l}\text { Percent decrease from historic } \\
\text { value }\end{array}$} \\
\hline & Historic & RCP 4.5 & RCP 6.0 & RCP 8.5 & RCP 4.5 & RCP 6.0 & RCP 8.5 \\
\hline Belize & 0 & - & - & - & - & - & - \\
\hline Guatemala & 4.65 & - & - & - & - & - & - \\
\hline Honduras & 2.57 & - & - & - & - & - & - \\
\hline El Salvador & 0.83 & - & - & - & - & - & - \\
\hline Nicaragua & 4.68 & $3-10$ & - & - & $\begin{array}{l}-135 \text { to } \\
37\end{array}$ & - & - \\
\hline
\end{tabular}

Table 14. Residential Rangelands 2050s epoch.

\begin{tabular}{|c|c|c|c|c|c|c|c|}
\hline & \multicolumn{4}{|c|}{ Percentage of total land } & \multicolumn{3}{|c|}{$\begin{array}{l}\text { Percent decrease from historic } \\
\text { value }\end{array}$} \\
\hline & Historic & RCP 4.5 & RCP 6.0 & RCP 8.5 & RCP 4.5 & RCP 6.0 & RCP 8.5 \\
\hline Belize & 0 & - & - & - & - & - & - \\
\hline Guatemala & 4.65 & - & - & - & - & - & - \\
\hline Honduras & 2.57 & - & - & - & - & - & - \\
\hline El Salvador & 0.83 & - & - & - & - & - & - \\
\hline Nicaragua & 4.68 & $3-20$ & - & $1-13$ & $\begin{array}{c}-360 \text { to } \\
28\end{array}$ & - & $\begin{array}{c}-190 \text { to } \\
65\end{array}$ \\
\hline
\end{tabular}

Table 15. Residential Rangelands 2080s epoch.

\begin{tabular}{|c|c|c|c|c|c|c|c|}
\hline & \multicolumn{4}{|c|}{ Percentage of total land } & \multicolumn{3}{c|}{ Percent decrease from historic } \\
& \multicolumn{4}{|c|}{} & \multicolumn{4}{|c|}{ value } \\
\cline { 2 - 8 } & Historic & RCP 4.5 & RCP 6.0 & RCP 8.5 & RCP 4.5 & RCP 6.0 & RCP 8.5 \\
\hline Belize & 0 & - & - & - & - & - & - \\
\hline Guatemala & 4.65 & - & - & - & - & - & - \\
\hline Honduras & 2.57 & - & - & - & - & - & - \\
\hline El Salvador & 0.83 & - & $1-10$ & $0-15$ & - & - & $\begin{array}{c}0 \\
1880\end{array}$ \\
\hline Nicaragua & 4.68 & $3-20$ & $2-18$ & $3-15$ & $\begin{array}{c}-18 \text { to }- \\
330\end{array}$ & $\begin{array}{c}-290 \text { to } \\
53\end{array}$ & $\begin{array}{c}-210 \text { to } \\
37\end{array}$ \\
\hline
\end{tabular}


Table 16. Residential Woodlands 2030s epoch.

\begin{tabular}{|c|c|c|c|c|c|c|c|}
\hline & \multicolumn{4}{|c|}{ Percentage of total land } & \multicolumn{3}{|c|}{$\begin{array}{l}\text { Percent decrease from historic } \\
\text { value }\end{array}$} \\
\hline & Historic & RCP 4.5 & RCP 6.0 & RCP 8.5 & RCP 4.5 & RCP 6.0 & RCP 8.5 \\
\hline Belize & 4.95 & $10-18$ & $10-25$ & $15-27$ & $\begin{array}{l}-110 \text { to }- \\
250\end{array}$ & $\begin{array}{l}-75 \text { to }- \\
600\end{array}$ & $\begin{array}{l}-200 \text { to }- \\
440\end{array}$ \\
\hline Guatemala & 10.95 & $5-10$ & $5-15$ & 5-12 & -5 to 50 & $\begin{array}{l}-45 \text { to } \\
85\end{array}$ & $\begin{array}{l}-12 \text { to } \\
40\end{array}$ \\
\hline Honduras & 22.56 & $\sim 25$ & $20-25$ & $\sim 25$ & -3 to -13 & -5 to 10 & -5 to -20 \\
\hline El Salvador & 1.0 & - & - & - & - & - & - \\
\hline Nicaragua & 4.26 & $5-10$ & $5-10$ & $5-10$ & $\begin{array}{l}-25 \text { to }- \\
165\end{array}$ & $\begin{array}{l}-40 \text { to }- \\
150\end{array}$ & $\begin{array}{l}-45 \text { to }- \\
140\end{array}$ \\
\hline
\end{tabular}

Table 17. Residential Woodlands 2050s epoch.

\begin{tabular}{|c|c|c|c|c|c|c|c|}
\hline & \multicolumn{4}{|c|}{ Percentage of total land } & \multicolumn{3}{|c|}{$\begin{array}{l}\text { Percent decrease from historic } \\
\text { value }\end{array}$} \\
\hline & Historic & RCP 4.5 & RCP 6.0 & RCP 8.5 & RCP 4.5 & RCP 6.0 & RCP 8.5 \\
\hline Belize & 4.95 & $10-35$ & $8-35$ & $8-45$ & $\begin{array}{l}-100 \text { to }- \\
625\end{array}$ & $\begin{array}{c}-75 \text { to }- \\
600\end{array}$ & $\begin{array}{c}-60 \text { to }- \\
835\end{array}$ \\
\hline Guatemala & 10.95 & - & $5-18$ & $4-15$ & - & -67 to 5 & $\begin{array}{l}-35 \text { to } \\
53\end{array}$ \\
\hline Honduras & 22.56 & $\sim 25$ & $\sim 25$ & $23-30$ & 0 to -20 & -4 to -12 & -3 to -33 \\
\hline El Salvador & 1.0 & - & - & - & - & - & - \\
\hline Nicaragua & 4.26 & $5-15$ & $5-12$ & $8-20$ & $\begin{array}{l}-30 \text { to }- \\
280\end{array}$ & $\begin{array}{l}-48 \text { to }- \\
175\end{array}$ & $\begin{array}{l}-80 \text { to }- \\
340\end{array}$ \\
\hline
\end{tabular}

Table 18. Residential Woodlands 2080s epoch.

\begin{tabular}{|c|c|c|c|c|c|c|c|}
\hline & \multicolumn{4}{|c|}{ Percentage of total land } & \multicolumn{3}{c|}{ Percent decrease from historic } \\
& Historic & RCP 4.5 & RCP 6.0 & RCP 8.5 & RCP 4.5 & RCP 6.0 & RCP 8.5 \\
\hline Belize & 4.95 & $18-55$ & $23-53$ & $3-60$ & $\begin{array}{c}-260 \text { to }- \\
1040\end{array}$ & $\begin{array}{c}-370 \text { to }- \\
965\end{array}$ & $\begin{array}{c}-1130 \text { to } \\
40\end{array}$ \\
\hline Guatemala & 10.95 & $5-25$ & $5-20$ & $3-15$ & -122 to 53 & $\begin{array}{c}-75 \text { to } \\
55\end{array}$ & $\begin{array}{c}-42 \text { to } \\
75\end{array}$ \\
\hline Honduras & 22.56 & $23-30$ & $\sim 25$ & $20-30$ & -1 to -35 & $\begin{array}{c}-10 \text { to }- \\
15\end{array}$ & $\begin{array}{c}-50 \text { to } \\
13\end{array}$ \\
\hline El Salvador & 1.0 & - & - & - & - & - & - \\
\hline Nicaragua & 4.26 & $5-15$ & $5-15$ & $5-25$ & $\begin{array}{c}-43 \text { to }- \\
270\end{array}$ & $\begin{array}{c}-30 \text { to }- \\
225\end{array}$ & $\begin{array}{c}-50 \text { to }- \\
500\end{array}$ \\
\hline
\end{tabular}


Table 19. Populated Woodlands 2030s epoch.

\begin{tabular}{|c|c|c|c|c|c|c|c|}
\hline & \multicolumn{4}{|c|}{ Percentage of total land } & \multicolumn{3}{c|}{ Percent decrease from historic } \\
& \multicolumn{4}{|c|}{} & \multicolumn{4}{|c|}{ value } \\
\cline { 2 - 9 } & Historic & RCP 4.5 & RCP 6.0 & RCP 8.5 & RCP 4.5 & RCP 6.0 & RCP 8.5 \\
\hline Belize & 82.81 & $53-65$ & $65-77$ & $58-65$ & $20-35$ & $7-20$ & $20-30$ \\
\hline Guatemala & 22.15 & $8-15$ & $13-23$ & $10-17$ & $30-65$ & -2 to 30 & $23-45$ \\
\hline Honduras & 28.48 & $\sim 25$ & $25-30$ & $20-28$ & $0-20$ & -5 to 13 & $2-30$ \\
\hline El Salvador & 0.52 & - & - & - & - & - & - \\
\hline \multirow{2}{*}{ Nicaragua } & 32.01 & $30-38$ & $8-45$ & $35-45$ & -20 to 5 & $\begin{array}{c}-10 \text { to }- \\
40\end{array}$ & -7 to -40 \\
\hline
\end{tabular}

Table 20. Populated Woodlands 2050s epoch.

\begin{tabular}{|c|c|c|c|c|c|c|c|}
\hline \multirow{2}{*}{} & \multicolumn{4}{|c|}{ Percentage of total land } & \multicolumn{3}{c|}{ Percent decrease from historic } \\
\cline { 2 - 9 } & Historic & RCP 4.5 & RCP 6.0 & RCP 8.5 & RCP 4.5 & RCP 6.0 & RCP 8.5 \\
\hline Belize & 82.81 & $30-63$ & $43-60$ & $23-58$ & $23-63$ & $25-50$ & $30-73$ \\
\hline Guatemala & 22.15 & $10-15$ & $10-15$ & $\sim 10$ & $40-58$ & $30-53$ & $55-63$ \\
\hline Honduras & 28.48 & $17-27$ & $\sim 25$ & $20-25$ & $5-38$ & $0-20$ & $7-30$ \\
\hline El Salvador & 0.52 & - & - & - & - & - & - \\
\hline Nicaragua & 32.01 & $15-38$ & $10-40$ & $20-35$ & -18 to 55 & $\begin{array}{c}-30 \text { to } \\
15\end{array}$ & $\begin{array}{c}-11 \text { to } \\
30\end{array}$ \\
\hline
\end{tabular}

Table 21. Populated Woodlands 2080s epoch.

\begin{tabular}{|c|c|c|c|c|c|c|c|}
\hline \multirow{2}{*}{} & \multicolumn{4}{|c|}{ Percentage of total land } & \multicolumn{3}{c|}{ Percent decrease from historic } \\
\cline { 2 - 9 } & Historic & RCP 4.5 & RCP 6.0 & RCP 8.5 & RCP 4.5 & RCP 6.0 & RCP 8.5 \\
\hline Belize & 82.81 & $15-63$ & $17-63$ & $1-48$ & $25-83$ & $25-80$ & $40-99$ \\
\hline Guatemala & 22.15 & $5-15$ & $7-10$ & - & $35-87$ & $50-68$ & - \\
\hline Honduras & 28.48 & $15-28$ & $13-27$ & $15-22$ & $1-43$ & $5-55$ & $23-45$ \\
\hline El Salvador & 0.52 & - & - & - & - & - & - \\
\hline Nicaragua & 32.01 & $15-35$ & $20-35$ & $15-28$ & -13 to 55 & -8 to 40 & $13-50$ \\
\hline
\end{tabular}


Table 22. Wild Woodlands 2030s epoch.

\begin{tabular}{|c|c|c|c|c|c|c|c|}
\hline & \multicolumn{4}{|c|}{ Percentage of total land } & \multicolumn{3}{c|}{ Percent decrease from historic } \\
& \multicolumn{4}{|c|}{} & \multicolumn{4}{|c|}{ value } \\
\cline { 2 - 9 } & Historic & RCP 4.5 & RCP 6.0 & RCP 8.5 & RCP 4.5 & RCP 6.0 & RCP 8.5 \\
\hline Belize & 1.53 & - & $1-12$ & - & - & $\begin{array}{c}-630 \text { to } \\
99\end{array}$ & - \\
\hline Guatemala & 6.81 & - & - & - & - & - & - \\
\hline Honduras & 4.44 & - & - & - & - & - & - \\
\hline El Salvador & 0 & - & - & - & - & - & - \\
\hline Nicaragua & 5.22 & - & - & - & - & - & - \\
\hline
\end{tabular}

Table 23. Wild Woodlands 2050s epoch.

\begin{tabular}{|c|c|c|c|c|c|c|c|}
\hline & \multicolumn{4}{|c|}{ Percentage of total land } & \multicolumn{3}{|c|}{$\begin{array}{l}\text { Percent decrease from historic } \\
\text { value }\end{array}$} \\
\hline & Historic & RCP 4.5 & RCP 6.0 & RCP 8.5 & RCP 4.5 & RCP 6.0 & RCP 8.5 \\
\hline Belize & 1.53 & $>0-11$ & - & - & $\begin{array}{c}-650 \text { to } \\
12\end{array}$ & - & - \\
\hline Guatemala & 6.81 & - & - & - & - & - & - \\
\hline Honduras & 4.44 & - & - & - & - & - & - \\
\hline El Salvador & 0 & - & - & - & - & - & - \\
\hline Nicaragua & 5.22 & - & - & - & - & - & - \\
\hline
\end{tabular}

Table 24. Wild Woodlands 2080s epoch.

\begin{tabular}{|c|c|c|c|c|c|c|c|}
\hline & \multicolumn{4}{|c|}{ Percentage of total land } & \multicolumn{3}{c|}{ Percent decrease from historic } \\
& \multicolumn{4}{|c|}{} & \multicolumn{4}{|c|}{ value } \\
\cline { 2 - 9 } & Historic & RCP 4.5 & RCP 6.0 & RCP 8.5 & RCP 4.5 & RCP 6.0 & RCP 8.5 \\
\hline Belize & 1.53 & - & - & - & - & - & - \\
\hline Guatemala & 6.81 & - & - & - & - & - & - \\
\hline Honduras & 4.44 & - & - & - & - & - & - \\
\hline El Salvador & 0 & - & - & - & - & - & - \\
\hline Nicaragua & 5.22 & - & - & - & - & - & - \\
\hline
\end{tabular}




\section{Biomes}

Table 25. Central American Atlantic Moist Forests 2030s epoch.

\begin{tabular}{|c|c|c|c|c|c|c|c|}
\hline & \multicolumn{4}{|c|}{ Percentage of total land } & \multicolumn{3}{|c|}{$\begin{array}{l}\text { Percent decrease from historic } \\
\text { value }\end{array}$} \\
\hline & Historic & RCP 4.5 & RCP 6.0 & RCP 8.5 & RCP 4.5 & RCP 6.0 & RCP 8.5 \\
\hline Belize & 0.07 & $>0-30$ & $>0-40$ & $1-43$ & $\begin{array}{l}-700 \text { to }- \\
47000\end{array}$ & $\begin{array}{l}-105 \text { to }- \\
59000\end{array}$ & $\begin{array}{l}-1500 \text { to } \\
-64000\end{array}$ \\
\hline Guatemala & 6.48 & $3-15$ & $3-20$ & $5-15$ & -115 to 60 & $\begin{array}{l}-190 \text { to } \\
45\end{array}$ & $\begin{array}{l}-3 \text { to }- \\
125\end{array}$ \\
\hline Honduras & 32.79 & $23-32$ & $\sim 30$ & $25-33$ & $2-30$ & -1 to 7 & $3-23$ \\
\hline Nicaragua & 36.51 & $30-50$ & $35-40$ & $30-40$ & -40 to 22 & -10 to 15 & -6 to 25 \\
\hline El Salvador & 0 & - & - & - & - & - & - \\
\hline
\end{tabular}

Table 26. Central American Atlantic Moist Forests 2050s epoch.

\begin{tabular}{|c|c|c|c|c|c|c|c|}
\hline & \multicolumn{4}{|c|}{ Percentage of total land } & \multicolumn{3}{c|}{ Percent decrease from historic } \\
& \multicolumn{1}{|c|}{ vistoric } & RCP 4.5 & RCP 6.0 & RCP 8.5 & RCP 4.5 & RCP 6.0 & RCP 8.5 \\
\hline \multirow{2}{*}{ Belize } & 0.07 & $1-30$ & $1-40$ & $0-40$ & $\begin{array}{c}-1300 \text { to }- \\
45000\end{array}$ & $\begin{array}{c}-1100 \text { to } \\
58000\end{array}$ & $\begin{array}{c}-60000 \\
\text { to } 100\end{array}$ \\
\hline Guatemala & 6.48 & $2-12$ & $2-17$ & $1-15$ & -90 to 68 & $\begin{array}{c}-170 \text { to } \\
70\end{array}$ & $\begin{array}{c}-147 \text { to } \\
82\end{array}$ \\
\hline Honduras & 32.79 & $20-30$ & $23-35$ & $20-32$ & $5-36$ & -3 to 30 & $5-35$ \\
\hline Nicaragua & 36.51 & $35-47$ & $30-40$ & $30-43$ & -30 to 5 & -13 to 15 & -17 to 20 \\
\hline El Salvador & 0 & - & - & - & - & - & - \\
\hline
\end{tabular}

Table 27. Central American Atlantic Moist Forests 2080s epoch.

\begin{tabular}{|c|c|c|c|c|c|c|c|}
\hline & \multicolumn{4}{|c|}{ Percentage of total land } & \multicolumn{3}{c|}{ Percent decrease from historic } \\
& \multicolumn{1}{|c|}{ Historic } & RCP 4.5 & RCP 6.0 & RCP 8.5 & RCP 4.5 & RCP 6.0 & RCP 8.5 \\
\hline Belize & 0.07 & $>0-40$ & $1-53$ & $0-40$ & $\begin{array}{c}-68000 \text { to } \\
90\end{array}$ & $\begin{array}{c}-890 \text { to }- \\
79000\end{array}$ & $\begin{array}{c}-61000 \\
\text { to } 100\end{array}$ \\
\hline Guatemala & 6.48 & $1-15$ & $1-18$ & $1-15$ & -155 to 90 & $\begin{array}{c}-180 \text { to } \\
80\end{array}$ & $\begin{array}{c}-140 \text { to } \\
80\end{array}$ \\
\hline Honduras & 32.79 & $20-35$ & $22-30$ & $17-30$ & -6 to 35 & $6-32$ & $13-45$ \\
\hline Nicaragua & 36.51 & $35-45$ & $30-47$ & $30-47$ & -20 to 0 & -28 to 15 & -30 to 15 \\
\hline El Salvador & 0 & - & - & - & - & - & - \\
\hline
\end{tabular}


Table 28. Isthmian-Atlantic Moist Forests 2030s epoch.

\begin{tabular}{|c|c|c|c|c|c|c|c|}
\hline & \multicolumn{4}{|c|}{ Percentage of total land } & \multicolumn{3}{|c|}{$\begin{array}{l}\text { Percent decrease from historic } \\
\text { value }\end{array}$} \\
\hline & Historic & RCP 4.5 & RCP 6.0 & RCP 8.5 & RCP 4.5 & RCP 6.0 & RCP 8.5 \\
\hline Belize & 0 & - & - & - & - & - & - \\
\hline Guatemala & 0.29 & - & - & - & - & - & - \\
\hline Honduras & 0 & - & - & - & - & - & - \\
\hline Nicaragua & 15.83 & $10-18$ & $10-17$ & $10-20$ & -15 to 45 & -6 to 40 & $\begin{array}{l}-30 \text { to } \\
35\end{array}$ \\
\hline El Salvador & 0 & - & - & - & - & - & - \\
\hline
\end{tabular}

Table 29. Isthmian-Atlantic Moist Forests 2050s epoch.

\begin{tabular}{|c|c|c|c|c|c|c|c|}
\hline & \multicolumn{4}{|c|}{ Percentage of total land } & \multicolumn{3}{|c|}{$\begin{array}{c}\text { Percent decrease from historic } \\
\text { value }\end{array}$} \\
\hline & Historic & RCP 4.5 & RCP 6.0 & RCP 8.5 & RCP 4.5 & RCP 6.0 & RCP 8.5 \\
\hline Belize & 0 & - & - & - & - & - & - \\
\hline Guatemala & 0.29 & - & - & - & - & - & - \\
\hline Honduras & 0 & - & - & - & - & - & - \\
\hline Nicaragua & 15.83 & $5-13$ & $10-17$ & $5-18$ & $18-65$ & -8 to 45 & $\begin{array}{l}-15 \text { to } \\
70\end{array}$ \\
\hline El Salvador & 0 & - & - & - & - & - & - \\
\hline
\end{tabular}

Table 30. Isthmian-Atlantic Moist Forests 2080s epoch.

\begin{tabular}{|c|c|c|c|c|c|c|c|}
\hline & \multicolumn{4}{|c|}{ Percentage of total land } & \multicolumn{3}{c|}{ Percent decrease from historic } \\
& \multicolumn{4}{|c|}{} & \multicolumn{4}{|c|}{ value } \\
\cline { 2 - 9 } & Historic & RCP 4.5 & RCP 6.0 & RCP 8.5 & RCP 4.5 & RCP 6.0 & RCP 8.5 \\
\hline Belize & 0 & - & - & - & - & - & - \\
\hline Guatemala & 0.29 & - & - & - & - & - & - \\
\hline Honduras & 0 & - & - & - & - & - & - \\
\hline Nicaragua & 15.83 & $3-13$ & $7-17$ & $1-18$ & $15-78$ & -5 to 53 & $\begin{array}{c}-15 \text { to } \\
90\end{array}$ \\
\hline El Salvador & 0 & - & - & - & - & - & - \\
\hline
\end{tabular}


Table 31. Pantanos De Centla 2030s epoch.

\begin{tabular}{|c|c|c|c|c|c|c|c|}
\hline & \multicolumn{4}{|c|}{ Percentage of total land } & \multicolumn{3}{c|}{ Percent decrease from historic } \\
& Historic & RCP 4.5 & RCP 6.0 & RCP 8.5 & RCP 4.5 & RCP 6.0 & RCP 8.5 \\
\hline \multirow{2}{*}{ Belize } & 0 & $2-25$ & $>0-30$ & $>0-30$ & $\begin{array}{c}\text { Increase } \\
\text { from 0 }\end{array}$ & $\begin{array}{c}\text { Increase } \\
\text { from 0 }\end{array}$ & $\begin{array}{c}\text { Increase } \\
\text { from 0 }\end{array}$ \\
\hline Guatemala & 0 & $7-20$ & $3-20$ & $8-15$ & $\begin{array}{c}\text { Increase } \\
\text { from 0 }\end{array}$ & $\begin{array}{c}\text { Increase } \\
\text { from 0 }\end{array}$ & $\begin{array}{c}\text { Increase } \\
\text { from 0 }\end{array}$ \\
\hline Honduras & 0 & - & - & - & - & - & - \\
\hline Nicaragua & 0 & - & - & - & - & - & - \\
\hline El Salvador & 0 & - & - & - & - & - & - \\
\hline
\end{tabular}

Table 32. Pantanos De Centla 2050s epoch.

\begin{tabular}{|c|c|c|c|c|c|c|c|}
\hline & \multicolumn{4}{|c|}{ Percentage of total land } & \multicolumn{3}{|c|}{$\begin{array}{l}\text { Percent decrease from historic } \\
\text { value }\end{array}$} \\
\hline & Historic & RCP 4.5 & RCP 6.0 & RCP 8.5 & RCP 4.5 & RCP 6.0 & RCP 8.5 \\
\hline Belize & 0 & $3-40$ & $3-38$ & $>0-48$ & $\begin{array}{l}\text { Increase } \\
\text { from } 0\end{array}$ & $\begin{array}{l}\text { Increase } \\
\text { from } 0\end{array}$ & $\begin{array}{l}\text { Increase } \\
\text { from } 0\end{array}$ \\
\hline Guatemala & 0 & $8-23$ & $10-25$ & $8-27$ & $\begin{array}{l}\text { Increase } \\
\text { from } 0\end{array}$ & $\begin{array}{l}\text { Increase } \\
\text { from } 0\end{array}$ & $\begin{array}{l}\text { Increase } \\
\text { from } 0\end{array}$ \\
\hline Honduras & 0 & - & - & $0-10$ & - & - & $\begin{array}{l}\text { Increase } \\
\text { from } 0\end{array}$ \\
\hline Nicaragua & 0 & - & - & - & - & - & - \\
\hline EI Salvador & 0 & - & - & - & - & - & - \\
\hline
\end{tabular}

Table 33. Pantanos De Centla 2080s epoch.

\begin{tabular}{|c|c|c|c|c|c|c|c|}
\hline & \multicolumn{4}{|c|}{ Percentage of total land } & \multicolumn{3}{c|}{ Percent decrease from historic } \\
& Historic & RCP 4.5 & RCP 6.0 & RCP 8.5 & RCP 4.5 & RCP 6.0 & RCP 8.5 \\
\cline { 2 - 8 } & 0 & $10-48$ & $7-48$ & $1-68$ & $\begin{array}{c}\text { Increase } \\
\text { from 0 }\end{array}$ & $\begin{array}{c}\text { Increase } \\
\text { from 0 }\end{array}$ & $\begin{array}{c}\text { Increase } \\
\text { from 0 }\end{array}$ \\
\hline Belize & 0 & $12-25$ & $5-30$ & $10-32$ & $\begin{array}{c}\text { Increase } \\
\text { from 0 }\end{array}$ & $\begin{array}{c}\text { Increase } \\
\text { from 0 }\end{array}$ & $\begin{array}{c}\text { Increase } \\
\text { from 0 }\end{array}$ \\
\hline Honduras & 0 & - & $0-15$ & $>0-22$ & - & $\begin{array}{c}\text { Increase } \\
\text { from 0 }\end{array}$ & $\begin{array}{c}\text { Increase } \\
\text { from 0 }\end{array}$ \\
\hline Nicaragua & 0 & - & - & - & - & - & - \\
\hline El Salvador & 0 & - & - & - & - & - & - \\
\hline
\end{tabular}


Table 34. Southern Pacific Dry Forests 2030s epoch.

\begin{tabular}{|c|c|c|c|c|c|c|c|}
\hline & \multicolumn{4}{|c|}{ Percentage of total land } & \multicolumn{3}{c|}{ Percent decrease from historic } \\
& \multicolumn{4}{|c|}{} & \multicolumn{4}{|c|}{ value } \\
\cline { 2 - 9 } & Historic & RCP 4.5 & RCP 6.0 & RCP 8.5 & RCP 4.5 & RCP 6.0 & RCP 8.5 \\
\hline Belize & 0 & - & - & - & - & - & - \\
\hline Guatemala & 0.82 & - & - & - & - & - & - \\
\hline Honduras & 0 & - & - & - & - & - & - \\
\hline Nicaragua & 0 & - & - & - & - & - & - \\
\hline El Salvador & 0 & - & - & - & - & - & - \\
\hline
\end{tabular}

Table 35. Southern Pacific Dry Forests 2050s epoch.

\begin{tabular}{|c|c|c|c|c|c|c|c|}
\hline & \multicolumn{4}{|c|}{ Percentage of total land } & \multicolumn{3}{c|}{ Percent decrease from historic } \\
& \multicolumn{4}{|c|}{} & \multicolumn{4}{|c|}{ value } \\
\cline { 2 - 9 } & Historic & RCP 4.5 & RCP 6.0 & RCP 8.5 & RCP 4.5 & RCP 6.0 & RCP 8.5 \\
\hline Belize & 0 & - & - & - & - & - & - \\
\hline Guatemala & 0.82 & - & - & - & - & - & - \\
\hline Honduras & 0 & - & - & - & - & - & - \\
\hline Nicaragua & 0 & $0-12$ & - & - & $\begin{array}{c}\text { Increase } \\
\text { from 0 }\end{array}$ & - & - \\
\hline El Salvador & 0 & - & - & - & - & - & - \\
\hline
\end{tabular}

Table 36. Southern Pacific Dry Forests 2080s epoch.

\begin{tabular}{|c|c|c|c|c|c|c|c|}
\hline & \multicolumn{4}{|c|}{ Percentage of total land } & \multicolumn{3}{c|}{ Percent decrease from historic } \\
& Historic & RCP 4.5 & RCP 6.0 & RCP 8.5 & RCP 4.5 & RCP 6.0 & RCP 8.5 \\
\hline Belize & 0 & - & - & - & - & - & - \\
\hline Guatemala & 0.82 & - & - & $3-10$ & - & - & $\begin{array}{c}-240 \text { to - } \\
1200\end{array}$ \\
\hline Honduras & 0 & - & - & - & - & - & - \\
\hline Nicaragua & 0 & $0-12$ & - & - & $\begin{array}{c}\text { Increase } \\
\text { from 0 }\end{array}$ & - & - \\
\hline El Salvador & 0 & - & - & $0-25$ & - & - & $\begin{array}{c}\text { Increase } \\
\text { from 0 }\end{array}$ \\
\hline
\end{tabular}


Table 37. Neotropic 2030s epoch.

\begin{tabular}{|c|c|c|c|c|c|c|c|}
\hline & \multicolumn{4}{|c|}{ Percentage of total land } & \multicolumn{3}{|c|}{$\begin{array}{c}\text { Percent decrease from historic } \\
\text { value }\end{array}$} \\
\hline & Historic & RCP 4.5 & RCP 6.0 & RCP 8.5 & RCP 4.5 & RCP 6.0 & RCP 8.5 \\
\hline Belize & 0 & - & - & - & - & - & - \\
\hline Guatemala & 0 & - & - & - & - & - & - \\
\hline Honduras & 0 & - & - & - & - & - & - \\
\hline Nicaragua & 7.09 & $\sim 10$ & 5-12 & $7-13$ & -15 to -57 & $\begin{array}{l}-70 \text { to } \\
17\end{array}$ & 0 to -82 \\
\hline El Salvador & 0 & - & - & - & - & - & - \\
\hline
\end{tabular}

Table 38. Neotropic 2050s epoch.

\begin{tabular}{|c|c|c|c|c|c|c|c|}
\hline & \multicolumn{4}{|c|}{ Percentage of total land } & \multicolumn{3}{|c|}{$\begin{array}{l}\text { Percent decrease from historic } \\
\text { value }\end{array}$} \\
\hline & Historic & RCP 4.5 & RCP 6.0 & RCP 8.5 & RCP 4.5 & RCP 6.0 & RCP 8.5 \\
\hline Belize & 0 & - & - & - & - & - & - \\
\hline Guatemala & 0 & - & - & - & - & - & - \\
\hline Honduras & 0 & - & - & - & - & - & - \\
\hline Nicaragua & 7.09 & $5-12$ & $5-13$ & $5-15$ & -70 to 43 & $\begin{array}{l}-85 \text { to } \\
15\end{array}$ & $\begin{array}{l}-98 \text { to } \\
26\end{array}$ \\
\hline El Salvador & 0 & - & - & - & - & - & - \\
\hline
\end{tabular}

Table 39. Neotropic 2080s epoch.

\begin{tabular}{|c|c|c|c|c|c|c|c|}
\hline & \multicolumn{4}{|c|}{ Percentage of total land } & \multicolumn{3}{|c|}{$\begin{array}{l}\text { Percent decrease from historic } \\
\text { value }\end{array}$} \\
\hline & Historic & RCP 4.5 & RCP 6.0 & RCP 8.5 & $\mathrm{RCP} 4.5$ & RCP 6.0 & RCP 8.5 \\
\hline Belize & Historic & RCP 4.5 & RCP 6.0 & RCP 8.5 & RCP 4.5 & RCP 6.0 & RCP 8.5 \\
\hline Guatemala & 0 & - & - & - & - & - & - \\
\hline Honduras & 0 & - & - & - & - & - & - \\
\hline Nicaragua & 0 & - & - & - & - & - & - \\
\hline El Salvador & 7.09 & 3-12 & $8-13$ & $3-13$ & -70 to 65 & -5 to -80 & $\begin{array}{c}-82 \text { to } \\
47\end{array}$ \\
\hline
\end{tabular}


Table 40. Petén-Veracruz Moist Forest 2030s epoch.

\begin{tabular}{|c|c|c|c|c|c|c|c|}
\hline & \multicolumn{4}{|c|}{ Percentage of total land } & \multicolumn{3}{c|}{ Percent decrease from historic } \\
& \multicolumn{4}{|c|}{} & \multicolumn{4}{|c|}{ value } \\
\cline { 2 - 9 } & Historic & RCP 4.5 & RCP 6.0 & RCP 8.5 & RCP 4.5 & RCP 6.0 & RCP 8.5 \\
\hline Belize & 86.67 & $25-60$ & $25-80$ & $25-35$ & $33-70$ & $10-68$ & $60-70$ \\
\hline Guatemala & 45.16 & $25-40$ & $15-42$ & $20-25$ & $13-47$ & $7-67$ & $42-55$ \\
\hline Honduras & 0.19 & $2-17$ & $>0-15$ & $>0-22$ & $\begin{array}{c}-1100 \text { to }- \\
8900\end{array}$ & $\begin{array}{c}-250 \text { to }- \\
8300\end{array}$ & $\begin{array}{c}-180 \text { to }- \\
12000\end{array}$ \\
\hline Nicaragua & 0.03 & - & - & - & - & - & - \\
\hline El Salvador & 0.00 & - & - & - & - & - & - \\
\hline
\end{tabular}

Table 41. Petén-Veracruz Moist Forest 2050s epoch.

\begin{tabular}{|c|c|c|c|c|c|c|c|}
\hline & \multicolumn{4}{|c|}{ Percentage of total land } & \multicolumn{3}{c|}{ Percent decrease from historic } \\
& \multicolumn{1}{|c|}{} & \multicolumn{4}{|c|}{ value } \\
\cline { 2 - 9 } & Historic & RCP 4.5 & RCP 6.0 & RCP 8.5 & RCP 4.5 & RCP 6.0 & RCP 8.5 \\
\hline Belize & 86.67 & $20-47$ & $22-50$ & $15-25$ & $45-77$ & $42-75$ & $73-83$ \\
\hline Guatemala & 45.16 & $20-30$ & $15-30$ & $17-27$ & $35-55$ & $30-67$ & $40-63$ \\
\hline Honduras & 0.19 & $5-22$ & $>0-20$ & $1-15$ & $\begin{array}{c}-2600 \text { to }- \\
12000\end{array}$ & $\begin{array}{c}-330 \text { to }- \\
10000\end{array}$ & $\begin{array}{c}-470 \text { to - } \\
8500\end{array}$ \\
\hline Nicaragua & 0.03 & - & - & - & - & - & - \\
\hline El Salvador & 0.00 & - & - & - & - & - & - \\
\hline
\end{tabular}

Table 42. Petén-Veracruz Moist Forest 2080s epoch.

\begin{tabular}{|c|c|c|c|c|c|c|c|}
\hline & \multicolumn{4}{|c|}{ Percentage of total land } & \multicolumn{3}{c|}{ Percent decrease from historic } \\
& \multicolumn{4}{|c|}{} & \multicolumn{4}{|c|}{ value } \\
\cline { 2 - 9 } & Historic & RCP 4.5 & RCP 6.0 & RCP 8.5 & RCP 4.5 & RCP 6.0 & RCP 8.5 \\
\hline Belize & 86.67 & $12-40$ & $10-35$ & $3-15$ & $55-85$ & $60-87$ & $80-97$ \\
\hline Guatemala & 45.16 & $10-30$ & $15-25$ & $17-22$ & $37-75$ & $45-65$ & $50-65$ \\
\hline Honduras & 0.19 & $5-20$ & $3-25$ & $5-20$ & $\begin{array}{c}-280 \text { to - } \\
11000\end{array}$ & $\begin{array}{c}-1500 \text { to } \\
-13000\end{array}$ & $\begin{array}{c}-2000 \text { to } \\
-10000\end{array}$ \\
\hline Nicaragua & 0.03 & - & - & - & - & - & - \\
\hline El Salvador & 0.00 & - & - & - & - & - & - \\
\hline
\end{tabular}


Table 43. Sierra Madre De Chiapas Moist Forest 2030s epoch.

\begin{tabular}{|c|c|c|c|c|c|c|c|}
\hline & \multicolumn{4}{|c|}{ Percentage of total land } & \multicolumn{3}{|c|}{$\begin{array}{l}\text { Percent decrease from historic } \\
\text { value }\end{array}$} \\
\hline & Historic & RCP 4.5 & RCP 6.0 & RCP 8.5 & RCP 4.5 & RCP 6.0 & RCP 8.5 \\
\hline Belize & 0 & - & - & - & - & - & - \\
\hline Guatemala & 3.80 & - & - & - & - & - & - \\
\hline Honduras & 0 & - & - & - & - & - & - \\
\hline Nicaragua & 0 & - & - & - & - & - & - \\
\hline El Salvador & 1.76 & - & - & $0-13$ & - & - & $\begin{array}{c}-635 \text { to } \\
100\end{array}$ \\
\hline
\end{tabular}

Table 44. Sierra Madre De Chiapas Moist Forest 2050s epoch.

\begin{tabular}{|c|c|c|c|c|c|c|c|}
\hline \multirow{2}{*}{} & \multicolumn{4}{|c|}{ Percentage of total land } & \multicolumn{3}{c|}{ Percent decrease from historic } \\
\cline { 2 - 9 } & Historic & RCP 4.5 & RCP 6.0 & RCP 8.5 & RCP 4.5 & RCP 6.0 & RCP 8.5 \\
\hline Belize & 0 & - & - & - & - & - & - \\
\hline Guatemala & 3.80 & - & - & - & - & - & - \\
\hline Honduras & 0 & - & - & - & - & - & - \\
\hline Nicaragua & 0 & - & - & - & - & - & - \\
\hline El Salvador & 1.76 & - & - & - & - & - & - \\
\hline
\end{tabular}

Table 45. Sierra Madre De Chiapas Moist Forest 2080s epoch.

\begin{tabular}{|c|c|c|c|c|c|c|c|}
\hline & \multicolumn{4}{|c|}{ Percentage of total land } & \multicolumn{3}{c|}{ Percent decrease from historic } \\
& \multicolumn{4}{|c|}{} & \multicolumn{4}{|c|}{ value } \\
\cline { 2 - 9 } & Historic & RCP 4.5 & RCP 6.0 & RCP 8.5 & RCP 4.5 & RCP 6.0 & RCP 8.5 \\
\hline Guatize & 0 & - & - & - & - & - & - \\
\hline Honduras & 0 & - & - & - & - & - & - \\
\hline Nicaragua & 0 & - & - & - & - & - & - \\
\hline El Salvador & 1.76 & - & - & $>0-15$ & - & - & $\begin{array}{c}-680 \text { to } \\
99\end{array}$ \\
\hline
\end{tabular}


Table 46. Veracruz Moist Forests 2030s epoch.

\begin{tabular}{|c|c|c|c|c|c|c|c|}
\hline & \multicolumn{4}{|c|}{ Percentage of total land } & \multicolumn{3}{c|}{ Percent decrease from historic } \\
& \multicolumn{4}{|c|}{} & \multicolumn{4}{|c|}{ value } \\
\cline { 2 - 9 } & Historic & RCP 4.5 & RCP 6.0 & RCP 8.5 & RCP 4.5 & RCP 6.0 & RCP 8.5 \\
\hline Belize & 0 & - & - & - & - & - & - \\
\hline Guatemala & 0 & - & - & - & - & - & - \\
\hline Honduras & 0 & - & - & - & - & - & - \\
\hline Nicaragua & 0 & - & - & - & - & - & - \\
\hline El Salvador & 0 & - & - & - & - & - & - \\
\hline
\end{tabular}

Table 47. Veracruz Moist Forests 2050s epoch.

\begin{tabular}{|c|c|c|c|c|c|c|c|}
\hline & \multicolumn{4}{|c|}{ Percentage of total land } & \multicolumn{3}{c|}{ Percent decrease from historic } \\
& \multicolumn{4}{|c|}{} & \multicolumn{4}{|c|}{ value } \\
\cline { 2 - 8 } & Historic & RCP 4.5 & RCP 6.0 & RCP 8.5 & RCP 4.5 & RCP 6.0 & RCP 8.5 \\
\hline Belize & 0 & - & - & - & - & - & - \\
\hline Guatemala & 0 & - & - & - & - & - & - \\
\hline Honduras & 0 & - & - & - & - & - & - \\
\hline Nicaragua & 0 & - & - & - & - & - & - \\
\hline El Salvador & 0 & - & - & - & - & - & - \\
\hline
\end{tabular}

Table 48. Veracruz Moist Forests 2080s epoch.

\begin{tabular}{|c|c|c|c|c|c|c|c|}
\hline & \multicolumn{4}{|c|}{ Percentage of total land } & \multicolumn{3}{c|}{ Percent decrease from historic } \\
& \multicolumn{4}{|c|}{} & \multicolumn{4}{|c|}{ value } \\
\cline { 2 - 9 } & Historic & RCP 4.5 & RCP 6.0 & RCP 8.5 & RCP 4.5 & RCP 6.0 & RCP 8.5 \\
\hline Belize & 0 & - & - & - & - & - & - \\
\hline Guatemala & 0 & - & - & $0-15$ & - & - & $\begin{array}{c}\text { Increase } \\
\text { from 0 }\end{array}$ \\
\hline Honduras & 0 & - & - & - & - & - & - \\
\hline Nicaragua & 0 & - & - & - & - & - & - \\
\hline El Salvador & 0 & - & - & - & - & - & - \\
\hline
\end{tabular}


Table 49. Yucatán Moist Forests 2030s epoch.

\begin{tabular}{|c|c|c|c|c|c|c|c|}
\hline & \multicolumn{4}{|c|}{ Percentage of total land } & \multicolumn{3}{c|}{$\begin{array}{c}\text { Percent decrease from } \\
\text { historic value }\end{array}$} \\
\cline { 2 - 9 } & Historic & RCP 4.5 & RCP 6.0 & RCP 8.5 & RCP 4.5 & RCP 6.0 & RCP 8.5 \\
\hline Belize & 1.38 & $0-10$ & - & - & $\begin{array}{c}-650 \text { to } \\
100\end{array}$ & - & - \\
\hline Guatemala & 0.20 & - & - & - & - & - & - \\
\hline Honduras & 0.16 & - & - & - & - & - & - \\
\hline Nicaragua & 0 & - & - & - & - & - & - \\
\hline El Salvador & 0 & - & - & - & - & - & - \\
\hline
\end{tabular}

Table 50. Yucatán Moist Forests 2050s epoch.

\begin{tabular}{|c|c|c|c|c|c|c|c|}
\hline & \multicolumn{4}{|c|}{ Percentage of total land } & \multicolumn{3}{c|}{ Percent decrease from historic } \\
& \multicolumn{4}{|c|}{} & \multicolumn{4}{|c|}{ value } \\
\cline { 2 - 9 } & Historic & RCP 4.5 & RCP 6.0 & RCP 8.5 & RCP 4.5 & RCP 6.0 & RCP 8.5 \\
\hline Belize & 1.38 & - & - & - & - & - & - \\
\hline Guatemala & 0.20 & - & - & - & - & - & - \\
\hline Honduras & 0.16 & - & - & - & - & - & - \\
\hline Nicaragua & 0 & - & - & - & - & - & - \\
\hline El Salvador & 0 & - & - & - & - & - & - \\
\hline
\end{tabular}

Table 51. Yucatán Moist Forests 2080s epoch.

\begin{tabular}{|c|c|c|c|c|c|c|c|}
\hline \multirow{2}{*}{} & \multicolumn{4}{|c|}{ Percentage of total land } & \multicolumn{3}{c|}{ Percent decrease from historic } \\
& \multicolumn{4}{|c|}{ value } \\
\cline { 2 - 9 } & Historic & RCP 4.5 & RCP 6.0 & RCP 8.5 & RCP 4.5 & RCP 6.0 & RCP 8.5 \\
\hline Belize & 1.38 & - & - & - & - & - & - \\
\hline Guatemala & 0.20 & - & - & - & - & - & - \\
\hline Honduras & 0.16 & - & - & - & - & - & - \\
\hline Nicaragua & 0 & - & - & - & - & - & - \\
\hline El Salvador & 0 & - & - & - & - & - & - \\
\hline
\end{tabular}


Table 52. Central American Dry Forests 2030s epoch.

\begin{tabular}{|c|c|c|c|c|c|c|c|}
\hline \multirow{2}{*}{} & \multicolumn{4}{|c|}{ Percentage of total land } & \multicolumn{3}{c|}{ Percent decrease from historic } \\
& Historic & RCP 4.5 & RCP 6.0 & RCP 8.5 & RCP 4.5 & RCP 6.0 & RCP 8.5 \\
\hline Belize & 0 & - & - & - & - & - & - \\
\hline Guatemala & 7.19 & $7-10$ & $\sim 10$ & $\sim 10$ & -48 to 7 & $\begin{array}{c}-13 \text { to }- \\
57\end{array}$ & -6 to -53 \\
\hline Honduras & 14.27 & $10-25$ & $15-23$ & $13-25$ & -70 to 25 & 0 to -60 & -75 to 7 \\
\hline Nicaragua & 19.54 & $18-25$ & $18-25$ & $18-25$ & -22 to 7 & -22 to 8 & $\begin{array}{c}-25 \\
10\end{array}$ \\
\hline El Salvador & 36.38 & $55-63$ & $50-68$ & $53-75$ & -73 to -50 & $\begin{array}{c}-40 \text { to }- \\
85\end{array}$ & $\begin{array}{c}-45 \text { to }- \\
100\end{array}$ \\
\hline
\end{tabular}

Table 53. Central American Dry Forests 2050s epoch.

\begin{tabular}{|c|c|c|c|c|c|c|c|}
\hline \multirow{2}{*}{} & \multicolumn{4}{|c|}{ Percentage of total land } & \multicolumn{3}{c|}{ Percent decrease from historic } \\
\cline { 2 - 8 } & Historic & RCP 4.5 & RCP 6.0 & RCP 8.5 & RCP 4.5 & RCP 6.0 & RCP 8.5 \\
\hline Belize & 0 & - & - & - & - & - & - \\
\hline Guatemala & 7.19 & $7-10$ & $\sim 10$ & $7-13$ & -53 to 8 & -6 to -60 & $\begin{array}{c}-80 \text { to } \\
11\end{array}$ \\
\hline Honduras & 14.27 & $10-22$ & $15-23$ & $5-30$ & -55 to 28 & -60 to 3 & $\begin{array}{c}-110 \text { to } \\
63\end{array}$ \\
\hline Nicaragua & 19.54 & $18-28$ & $18-27$ & $20-30$ & -40 to 7 & -37 to 8 & -60 to 5 \\
\hline El Salvador & 36.38 & $55-70$ & $55-73$ & $60-78$ & -50 to -97 & $\begin{array}{c}-55 \text { to }- \\
100\end{array}$ & $\begin{array}{c}-60 \text { to }- \\
115\end{array}$ \\
\hline
\end{tabular}

Table 54. Central American Dry Forests 2080s epoch.

\begin{tabular}{|c|c|c|c|c|c|c|c|}
\hline & \multicolumn{4}{|c|}{ Percentage of total land } & \multicolumn{3}{c|}{ Percent decrease from historic } \\
\cline { 2 - 9 } & Historic & RCP 4.5 & RCP 6.0 & RCP 8.5 & RCP 4.5 & RCP 6.0 & RCP 8.5 \\
\hline Belize & 0 & - & - & - & - & - & - \\
\hline Guatemala & 7.19 & $7-12$ & $\sim 10$ & $\sim 10$ & 0 to -72 & $\begin{array}{c}-25 \text { to }- \\
65\end{array}$ & $\begin{array}{c}-18 \text { to - } \\
67\end{array}$ \\
\hline Honduras & 14.27 & $15-20$ & $8-28$ & $3-27$ & -42 to 4 & $\begin{array}{c}-93 \text { to } \\
45\end{array}$ & $\begin{array}{c}-90 \text { to } \\
83\end{array}$ \\
\hline Nicaragua & 19.54 & $17-30$ & $18-30$ & $18-35$ & -46 to 10 & -50 to 8 & -75 to 5 \\
\hline El Salvador & 36.38 & $53-70$ & $50-70$ & $25-65$ & -45 to -90 & $\begin{array}{c}-40 \\
90\end{array}$ & $\begin{array}{c}-80 \text { to } \\
33\end{array}$ \\
\hline
\end{tabular}


Table 55. Yucatán Dry Forests 2030s epoch.

\begin{tabular}{|c|c|c|c|c|c|c|c|}
\hline \multirow{2}{*}{} & \multicolumn{4}{|c|}{ Percentage of total land } & \multicolumn{3}{c|}{ Percent decrease from historic } \\
\cline { 2 - 9 } & Historic & RCP 4.5 & RCP 6.0 & RCP 8.5 & RCP 4.5 & RCP 6.0 & RCP 8.5 \\
\hline Belize & 0 & - & - & - & - & - & - \\
\hline Guatemala & 0 & - & - & - & - & - & - \\
\hline Honduras & 0.001 & - & - & - & - & - & - \\
\hline Nicaragua & 0 & - & - & - & - & - & - \\
\hline El Salvador & 0 & - & - & - & - & - & - \\
\hline
\end{tabular}

Table 56. Yucatán Dry Forests 2050s epoch.

\begin{tabular}{|c|c|c|c|c|c|c|c|}
\hline & \multicolumn{4}{|c|}{ Percentage of total land } & \multicolumn{3}{|c|}{$\begin{array}{l}\text { Percent decrease from historic } \\
\text { value }\end{array}$} \\
\hline & Historic & RCP 4.5 & RCP 6.0 & RCP 8.5 & RCP 4.5 & RCP 6.0 & RCP 8.5 \\
\hline Belize & 0 & - & - & - & - & - & - \\
\hline Guatemala & 0 & - & - & - & - & - & - \\
\hline Honduras & 0.001 & $>0-10$ & - & $>0-15$ & $\begin{array}{l}-71000 \text { to }- \\
1370000\end{array}$ & - & $\begin{array}{c}-104000 \\
\text { to - } \\
1900000\end{array}$ \\
\hline Nicaragua & 0 & - & - & - & - & - & - \\
\hline El Salvador & 0 & - & - & - & - & - & - \\
\hline
\end{tabular}

Table 57. Yucatán Dry Forests 2080s epoch.

\begin{tabular}{|c|c|c|c|c|c|c|c|}
\hline & \multicolumn{4}{|c|}{ Percentage of total land } & \multicolumn{3}{c|}{ Percent decrease from historic } \\
& \multicolumn{1}{|c|}{ value } \\
\cline { 2 - 8 } & Historic & RCP 4.5 & RCP 6.0 & RCP 8.5 & RCP 4.5 & RCP 6.0 & RCP 8.5 \\
\hline Gelize & 0 & - & - & $0-13$ & - & - & $\begin{array}{c}\text { Increase } \\
\text { from 0 }\end{array}$ \\
\hline Guatemala & 0 & - & - & - & - & - & - \\
\hline Nicaragua & 0 & - & - & - & - & - & - \\
\hline El Salvador & 0 & - & - & - & - & - & - \\
\hline
\end{tabular}


Table 58. Central American Pine-Oak Forests 2030s epoch.

\begin{tabular}{|c|c|c|c|c|c|c|c|}
\hline \multirow{2}{*}{} & \multicolumn{4}{|c|}{ Percentage of total land } & \multicolumn{3}{c|}{ Percent decrease from historic } \\
\cline { 2 - 9 } & Historic & RCP 4.5 & RCP 6.0 & RCP 8.5 & RCP 4.5 & RCP 6.0 & RCP 8.5 \\
\hline Belize & 0 & - & - & - & - & - & - \\
\hline Guatemala & 28.95 & $20-27$ & $\sim 25$ & $\sim 25$ & $7-28$ & $5-20$ & $8-18$ \\
\hline Honduras & 41.80 & $20-30$ & $20-32$ & $15-32$ & $23-48$ & $25-55$ & $23-65$ \\
\hline Nicaragua & 8.41 & - & - & - & - & - & - \\
\hline El Salvador & 58.84 & $25-35$ & $22-43$ & $20-37$ & $40-58$ & $28-62$ & $37-67$ \\
\hline
\end{tabular}

Table 59. Central American Pine-Oak Forests 2050s epoch.

\begin{tabular}{|c|c|c|c|c|c|c|c|}
\hline \multirow{2}{*}{} & \multicolumn{4}{|c|}{ Percentage of total land } & \multicolumn{3}{c|}{ Percent decrease from historic } \\
\cline { 2 - 9 } & Historic & RCP 4.5 & RCP 6.0 & RCP 8.5 & RCP 4.5 & RCP 6.0 & RCP 8.5 \\
\hline Belize & 0 & - & - & - & - & - & - \\
\hline Guatemala & 28.95 & $15-25$ & $20-25$ & $15-25$ & $15-43$ & $10-30$ & $18-45$ \\
\hline Honduras & 41.80 & $10-28$ & $13-33$ & $5-25$ & $32-75$ & $23-68$ & $37-85$ \\
\hline Nicaragua & 8.41 & - & - & - & - & - & - \\
\hline El Salvador & 58.84 & $10-30$ & $15-33$ & $5-20$ & $50-80$ & $45-75$ & $67-92$ \\
\hline
\end{tabular}

Table 60. Central American Pine-Oak Forests 2080s epoch.

\begin{tabular}{|c|c|c|c|c|c|c|c|}
\hline \multirow{2}{*}{} & \multicolumn{4}{|c|}{ Percentage of total land } & \multicolumn{3}{c|}{ Percent decrease from historic } \\
\cline { 2 - 8 } & Historic & RCP 4.5 & RCP 6.0 & RCP 8.5 & RCP 4.5 & RCP 6.0 & RCP 8.5 \\
\hline Belize & 0 & - & - & - & - & - & - \\
\hline Guatemala & 28.95 & $20-25$ & $\sim 20$ & $10-18$ & $12-40$ & $25-40$ & $38-67$ \\
\hline Honduras & 41.80 & $8-27$ & $5-25$ & $1-15$ & $35-80$ & $37-85$ & $63-97$ \\
\hline Nicaragua & 8.41 & - & - & - & - & - & - \\
\hline El Salvador & 58.84 & $7-30$ & $6-15$ & - & $50-87$ & $75-90$ & - \\
\hline
\end{tabular}


Table 61. Miskito Pine Forests 2030s epoch.

\begin{tabular}{|c|c|c|c|c|c|c|c|}
\hline & \multicolumn{4}{|c|}{ Percentage of total land } & \multicolumn{3}{c|}{ Percent decrease from historic } \\
& \multicolumn{4}{|c|}{} & \multicolumn{4}{|c|}{ value } \\
\cline { 2 - 9 } & Historic & RCP 4.5 & RCP 6.0 & RCP 8.5 & RCP 4.5 & RCP 6.0 & RCP 8.5 \\
\hline Belize & 0.10 & - & - & - & - & - & - \\
\hline Guatemala & 0.00 & - & - & - & - & - & - \\
\hline Honduras & 5.21 & - & - & - & - & - & - \\
\hline Nicaragua & 9.63 & $4-13$ & $\sim 10$ & $\sim 10$ & -40 to 63 & -25 to 7 & -33 to 2 \\
\hline El Salvador & 0.00 & - & - & - & - & - & - \\
\hline
\end{tabular}

Table 62. Miskito Pine Forests 2050s epoch.

\begin{tabular}{|c|c|c|c|c|c|c|c|}
\hline & \multicolumn{4}{|c|}{ Percentage of total land } & \multicolumn{3}{|c|}{$\begin{array}{l}\text { Percent decrease from historic } \\
\text { value }\end{array}$} \\
\hline & Historic & RCP 4.5 & RCP 6.0 & RCP 8.5 & RCP 4.5 & RCP 6.0 & RCP 8.5 \\
\hline Belize & 0.10 & - & - & - & - & - & - \\
\hline Guatemala & 0.00 & - & - & - & - & - & - \\
\hline Honduras & 5.21 & - & - & - & - & - & - \\
\hline Nicaragua & 9.63 & $2-12$ & $8-13$ & $8-13$ & -25 to 78 & $\begin{array}{c}-30 \text { to } \\
17\end{array}$ & $\begin{array}{l}-33 \text { to } \\
22\end{array}$ \\
\hline El Salvador & 0.00 & - & - & - & - & - & - \\
\hline
\end{tabular}

Table 63. Miskito Pine Forests 2080 s epoch.

\begin{tabular}{|c|c|c|c|c|c|c|c|}
\hline & \multicolumn{4}{|c|}{ Percentage of total land } & \multicolumn{3}{c|}{ Percent decrease from historic } \\
& \multicolumn{4}{|c|}{} & \multicolumn{4}{|c|}{ value } \\
\cline { 2 - 9 } & Historic & RCP 4.5 & RCP 6.0 & RCP 8.5 & RCP 4.5 & RCP 6.0 & RCP 8.5 \\
\hline Belize & 0.10 & - & - & - & - & - & - \\
\hline Guatemala & 0.00 & - & - & - & - & - & - \\
\hline Honduras & 5.21 & - & - & - & - & - & - \\
\hline Nicaragua & 9.63 & $>0-10$ & $5-12$ & - & -15 to 95 & $\begin{array}{c}-28 \text { to } \\
50\end{array}$ & - \\
\hline El Salvador & 0.00 & - & - & - & - & - & - \\
\hline
\end{tabular}


Table 64. Mesoamerican Gulf-Caribbean Mangroves 2030s epoch.

\begin{tabular}{|c|c|c|c|c|c|c|c|}
\hline \multirow{2}{*}{} & \multicolumn{4}{|c|}{ Percentage of total land } & \multicolumn{3}{c|}{ Percent decrease from historic } \\
& Historic & RCP 4.5 & RCP 6.0 & RCP 8.5 & RCP 4.5 & RCP 6.0 & RCP 8.5 \\
\cline { 2 - 9 } Belize & 8.49 & $20-48$ & $15-40$ & $18-47$ & $\begin{array}{c}-130 \text { to }- \\
460\end{array}$ & $\begin{array}{c}-75 \text { to }- \\
390\end{array}$ & $\begin{array}{c}-110 \text { to }- \\
450\end{array}$ \\
\hline Guatemala & 0.19 & - & - & - & - & - & - \\
\hline Honduras & 1.66 & - & - & - & - & - & - \\
\hline Nicaragua & 1.90 & - & - & - & - & - & - \\
\hline El Salvador & 0.00 & - & - & - & - & - & - \\
\hline
\end{tabular}

Table 65. Mesoamerican Gulf-Caribbean Mangroves 2050s epoch.

\begin{tabular}{|c|c|c|c|c|c|c|c|}
\hline & \multicolumn{4}{|c|}{ Percentage of total land } & \multicolumn{3}{|c|}{$\begin{array}{l}\text { Percent decrease from historic } \\
\text { value }\end{array}$} \\
\hline & Historic & RCP 4.5 & RCP 6.0 & RCP 8.5 & RCP 4.5 & RCP 6.0 & RCP 8.5 \\
\hline Belize & 8.49 & $20-45$ & $22-45$ & $23-62$ & $\begin{array}{l}-150 \text { to }- \\
420\end{array}$ & $\begin{array}{l}-160 \text { to }- \\
440\end{array}$ & $\begin{array}{l}-170 \text { to }- \\
630\end{array}$ \\
\hline Guatemala & 0.19 & - & - & - & - & - & - \\
\hline Honduras & 1.66 & - & - & - & - & - & - \\
\hline Nicaragua & 1.90 & - & - & - & - & - & - \\
\hline El Salvador & 0.00 & - & - & - & - & - & - \\
\hline
\end{tabular}

Table 66. Mesoamerican Gulf-Caribbean Mangroves 2080s epoch.

\begin{tabular}{|c|c|c|c|c|c|c|c|}
\hline & \multicolumn{4}{|c|}{ Percentage of total land } & \multicolumn{3}{c|}{ Percent decrease from historic } \\
& \multicolumn{1}{|c|}{} & \multicolumn{4}{|c|}{ value } \\
\cline { 2 - 9 } & Historic & RCP 4.5 & RCP 6.0 & RCP 8.5 & RCP 4.5 & RCP 6.0 & RCP 8.5 \\
\hline Belize & 8.49 & $15-43$ & $27-55$ & $23-38$ & $\begin{array}{c}-85 \text { to - } \\
400\end{array}$ & $\begin{array}{c}-220 \text { to }- \\
560\end{array}$ & $\begin{array}{c}-180 \text { to }- \\
340\end{array}$ \\
\hline Guatemala & 0.19 & - & - & $3-10$ & - & - & $\begin{array}{c}-1400 \text { to } \\
-5200\end{array}$ \\
\hline Honduras & 1.66 & - & - & - & - & - & - \\
\hline Nicaragua & 1.90 & - & - & - & - & - & - \\
\hline El Salvador & 0.00 & - & - & - & - & - & - \\
\hline
\end{tabular}


Table 67. Southern Mesoamerican Pacific Mangroves 2030s epoch.

\begin{tabular}{|c|c|c|c|c|c|c|c|}
\hline & \multicolumn{4}{|c|}{ Percentage of total land } & \multicolumn{3}{|c|}{$\begin{array}{c}\text { Percent decrease from historic } \\
\text { value }\end{array}$} \\
\hline & Historic & RCP 4.5 & RCP 6.0 & RCP 8.5 & RCP 4.5 & RCP 6.0 & RCP 8.5 \\
\hline Belize & 0 & - & - & - & - & - & - \\
\hline Guatemala & 0.99 & - & - & - & - & - & - \\
\hline Honduras & 1.40 & - & - & - & - & - & - \\
\hline Nicaragua & 0.73 & - & - & - & - & - & - \\
\hline El Salvador & 0.15 & - & - & $4-15$ & - & - & $\begin{array}{l}-2900 \text { to } \\
-9300\end{array}$ \\
\hline
\end{tabular}

Table 68. Southern Mesoamerican Pacific Mangroves 2030s epoch.

\begin{tabular}{|c|c|c|c|c|c|c|c|}
\hline & \multicolumn{4}{|c|}{ Percentage of total land } & \multicolumn{3}{|c|}{$\begin{array}{l}\text { Percent decrease from historic } \\
\text { value }\end{array}$} \\
\hline & Historic & RCP 4.5 & RCP 6.0 & RCP 8.5 & RCP 4.5 & RCP 6.0 & RCP 8.5 \\
\hline Belize & 0 & - & - & - & - & - & - \\
\hline Guatemala & 0.99 & - & - & - & - & - & - \\
\hline Honduras & 1.40 & - & - & - & - & - & - \\
\hline Nicaragua & 0.73 & - & - & - & - & - & - \\
\hline El Salvador & 0.15 & $4-25$ & $5-15$ & $10-30$ & $\begin{array}{l}-2700 \text { to }- \\
16000\end{array}$ & $\begin{array}{l}-3200 \text { to } \\
-9500\end{array}$ & $\begin{array}{r}7200 \text { to }- \\
20000\end{array}$ \\
\hline
\end{tabular}

Table 69. Southern Mesoamerican Pacific Mangroves 2030s epoch.

\begin{tabular}{|c|c|c|c|c|c|c|c|}
\hline \multirow{2}{*}{} & \multicolumn{4}{|c|}{ Percentage of total land } & \multicolumn{3}{c|}{ Percent decrease from historic } \\
& \multicolumn{4}{|c|}{ value } \\
\cline { 2 - 9 } & Historic & RCP 4.5 & RCP 6.0 & RCP 8.5 & RCP 4.5 & RCP 6.0 & RCP 8.5 \\
\hline Belize & 0 & - & - & - & - & - & - \\
\hline Guatemala & 0.99 & - & - & - & - & - & - \\
\hline Honduras & 1.40 & - & - & - & - & - & - \\
\hline Nicaragua & 0.73 & - & - & - & - & - & - \\
\hline El Salvador & 0.15 & $5-30$ & $10-33$ & $15-72$ & $\begin{array}{c}-3300 \text { to }- \\
21000\end{array}$ & $\begin{array}{c}-6300 \text { to } \\
-22000\end{array}$ & $\begin{array}{c}-6800 \text { to } \\
-50000\end{array}$ \\
\hline
\end{tabular}




\section{Unit Conversion Factors}

\begin{tabular}{|l|l|l|}
\hline Multiply & By & To Obtain \\
\hline miles (U.S. Statute) & $1,609.347$ & meters \\
\hline
\end{tabular}




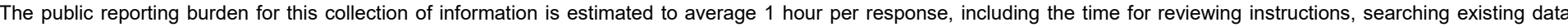

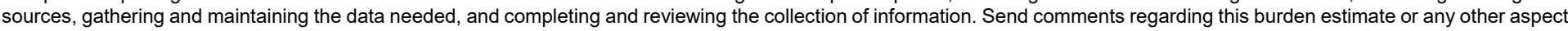

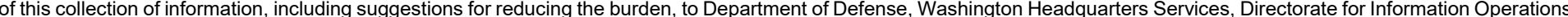

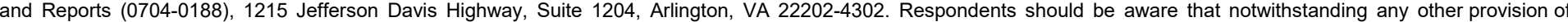
law, no person shall be subject to any penalty for failing to comply with a collection of information if it does not display a currently valid OMB control number. PLEASE DO NOT RETURN YOUR FORM TO THE ABOVE ADDRESS.

\begin{tabular}{l|l}
\hline $\begin{array}{l}\text { 1. REPORT DATE } \\
\text { September } 2019\end{array}$ & $\begin{array}{l}\text { 2. REPORT TYPE } \\
\text { Final Report }\end{array}$ \\
\hline
\end{tabular}

\section{TITLE AND SUBTITLE}

Projecting Shifts in Human and Ecological Zones
3. DATES COVERED (From - To)

5a. CONTRACT NUMBER

5b. GRANT NUMBER

5c. PROGRAM ELEMENT NUMBER

5d. PROJECT NUMBER

477345

Kayla A. Cotterman, James D. Westervelt, Jeanne M. Roningen, and Angela M. Rhodes 5e. TASK NUMBER

\section{5f. WORK UNIT NUMBER}

\section{PERFORMING ORGANIZATION REPORT NUMBER}

ERDC TR-19-23

10. SPONSOR/MONITOR'S ACRONYM(S) ERDC CERL

\section{SPONSOR/MONITOR'S} REPORT NUMBER(S)

2902 Newmark Dr.

Champaign, IL 61822

12. DISTRIBUTION/AVAILABILITY STATEMENT

Approved for public release; distribution is unlimited.

\section{SUPPLEMENTARY NOTES}

\section{ABSTRACT}

As the human population approaches 7.7 billion, Earth's capacity to support human life is stretched. There are declining opportunities for the expansion of human agriculture and settlements into new places. Additionally, there is an expected increase in the motivation for local people to defend land that currently supports the production of essential food and water. As climate non-stationarity continues, changes in the productivity of local food and water supply could result in starvation or surpluses. This study addresses the following question regarding the future potential of land resources to support local populations with food and water: How might existing ecological and anthropogenic biomes shift over the twenty-first century? Recent historic ecological and anthropogenic biome maps are statistically correlated with recent historic climate to generate models. These are then applied to anticipated future climates to generate future biome and anthrome maps. These maps are evaluated and summarized to suggest how the future climate might change and affect land use patterns. This analysis is constrained to the area of Central America over the course of the twenty-first century based on the results of recent climate models. However, it is a goal of the authors that the methods developed in this work can be applied to other regions of the world.

\section{SUBJECT TERMS}

Central America, Climatic changes_-Forecasting, Ecological provinces, Food supply, Land use, Land use mapping, Water-supply

16. SECURITY CLASSIFICATION OF:

\begin{tabular}{|l|c|l|l|}
\hline a. REPORT & b. ABSTRACT & c. THIS PAGE & ABSTRACT \\
Unclassified & Unclassified & Unclassified & SAR \\
& & &
\end{tabular}

18. NUMBER OF PAGES

94 19a. NAME OF RESPONSIBLE PERSON

19b. TELEPHONE NUMBER (Include area code) 601-634-5507 
7. PERFORMING ORGANIZATION NAME(S) AND ADDRESS(ES) (continued)

Coastal and Hydraulics Laboratory

U.S. Army Engineer Research and Development Center 3909 Halls Ferry Road

Vicksburg, MS 39180-6199

Construction Engineering Research Laboratory

U.S. Army Engineer Research and Development Center 2902 Newmark Drive

Champaign, IL 61822

Cold Regions Research and Engineering Laboratory

U.S. Army Engineer Research and Development Center 72 Lyme Road

Hanover, NH 03755 